\title{
AVALIAÇÃO DE POPULAÇÕES E HÍBRIDOS DE GALINHAS PARA CORTE QUANTO A TAXA DE CRESCIMENTO E CARACTERISTICAS DE CARCAÇA
}

\author{
GILBERTO SILBER SCHMIDT
}

Orientador: RANDOLFO WILLIAM SILVESTRE CUSTÓDIO

\begin{abstract}
Dissertação apresentada à Escola Superior de Agricultura "Luiz de Queiroz", da Universidade de São Paulo, para obtenção do título de Mestre em Agronomia. Área de concentração: Genética e Melhoramento de Plantas.
\end{abstract}

$P$ IR A C I C A B A

Estado de São Paulo - Brasil

Dezembro - 1983 
DEDICO

$\bar{A}$ minha esposa

ELZA PAULA

e filhos

LEANDRO, MARCEL E GILBERTO

pelo apoio, amor e compreensão.

Aos meus pais

JOÃO e IGNÊS

e irmãos

SIDNEY, MÁRIO, ROSELI e MARISE, pelo constante apoio e dedicação na minha formação. 


\section{AGRADECIMENTOS}

Ao Professor Dr. Randolfo William Silvestre Custódio, orientador e mestre que me orientou na condução deste trabalho e na minha vida profissional.

Ao Professor Irineu Umberto Packer, pelo apoio e incentivo na elaboração deste trabalho.

Aos Professores Dr. Geraldo Antonio Tosello e Dr. Gehard Bandel, pelo apoio recebido durante à realização do Curso de Mestrado.

Aos Professores do Curso de Pós-Graduação em "Genética.e Melhoramento de Plantas", pelos ensinamentos ministrados.

Ao Sr. Jair de Oliveira, e demais funcionários do setor de $\underline{A}$ ves do Departamento de Genética, pela indispensável colaboração na criação das aves, condução do experimento e co leta de dados.

Aos Colegas do Curso de Pós-Graduação em "Genética e Melhoramento de Plantas", pela amizade durante o tempo de convívio. 
Às Técnicas Maria de Fátima Martins e Marta Regina Travaine, pela amizade e incentivo durante à realização do Curso de Mestrado.

À BIG BIRDS S/A Produtos Avícolas, pela concessão de matéria-prima necessária para a realização do experimento.

Ao CNPq pela concessão da Bolsa de Estudo.

À Professora Neli Marisa de Azevedo Silva, pela amizade e colaboração prestada durante a elaboração deste trabalho.

Aos Docentes do Departamento de Produção Animal da Faculdade de Medicina Veterinária e Zootecnia da USP, Pirassunun ga, pelo apoio e incentivo.

A todos àqueles que direta ou indiretamente, contribuíram para a realização deste trabalho. 


\section{"CURRICULUM VITAE"}

\section{Nome: GILBERTO SILBER SCEMIDT}

Data de nascimento: 05 de julho de 1956

Local de nascimento: São Paulo, SP, Brasil

Formação Universitária: Zootecnista, 1980, pela Faculdade de Ciências Agrárias e Veterinárias de Jaboticabal, da Universidade do Esta do de são Paulo.

Atividade anterior: Contratado pela Escola Superior de Agricultura "Luiz de Queiroz", USP, de setem bro de 1982 a julho de 1983, como auxiliar de ensino, para ministrar aulas nas disciplinas de Métodos de Melhoramento, Genética; Citologia e Genética e Melhora mento de Aves.

Atividade atual: Auxiliar de Ensino do Departamento de Produ ção Animal da Faculdade de Medicina Veterinária e Zootecnia da USP, Pirassununga, SP, responsável pelas áreas de Melhoramento Genético Animal, Estatística e Estatística Ex perimental. 


\section{INDICE}

Página .

LISTA DE TABELAS................................ vii

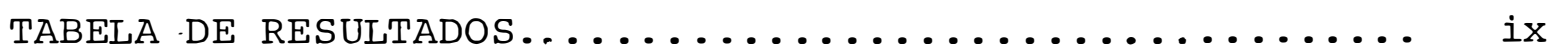

LISTA DE FIGURAS...................... XII

RESUMO.................................. xii

SUMMARY................................ xvi

1. INTRODUÇÃO.............................. 1

2. REVISÃo de Literatura..................... 5

2.1. Taxa de Crescimento.................... 5

2.2. Gordura Abdominal.................... 9

2.3. Rendimento de Carcaça.................... 14

2.4. Coeficiente de herdabilidade............. 18

2.5. Correlações Genéticas, Fenotípicas e Ambientais... 25

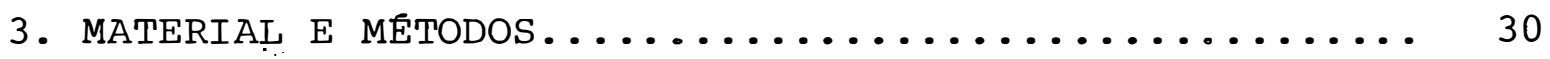

3.1. Local, Instalações e Equipamentos............ 30

3.2. Descrição dos Materiais Genéticos envolvidos no Experimento........................ 32

3.3. Manejo das aves..................... 32

3.4. Caracteristicas avaliadas.............. 37

3.4.1. Consumo de ração, peso corporal, conversão alimentar e viabilidade............. 37

3.4.2. Rendimento de carcaça.............. 39

3.5. Delineamento Experimental............. 40 
4. RESULTADOS E DISCUSSÃO..................... 43

4.1. Consumo de Ração, Ganho de Peso e Peso Corporal... 43

4.1.1. Fase inicial (0 - 35 dias)........... 44

4.1.2. Fase final $(36$ - 49 dias $) \ldots \ldots \ldots . \ldots \ldots 6$

4.2. Conversão alimentar.................... 52

4.3. Viabilidade........................... 54

4.4. Rendimento de Carcaça e Gurdura Abdominal...... 56

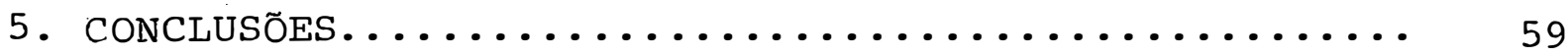

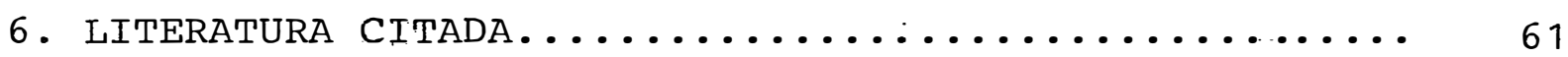

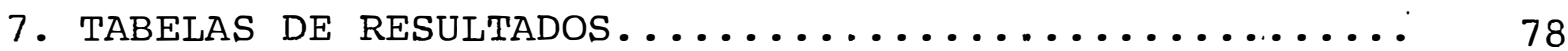




\section{LISTA DE TABELAS}

Tabela

Página

Desempenho de linhagens comerciais: para características de interesse econômico (56 dias de idade).................

Rendimento porcentual das várias partes em relação ao peso vivo e peso da carcaça eviscerada (CAMPOS e CHQUILOFF, 1966).

Coeficiente de correlação simples (r) pa ra diversas partes da carcaça (CHQUILOFF e CAMPOS, 1967) ...................

4 Número de reprodutores empregados, número de ovos incubados (NOI), peso 'médio dos ovos (PMO), número de pintos nasci dos (NP) e peso médio dos pintos (PP) ...

Composição do premix, níveis por tonelada de ração acabada................. 
TABELAS DE RESULTADOS

7 Consumo semanal médio $(\mathrm{g})$ : de ração, por ave

8 Análise de variância para os dados obtidos semanalmente para consumo de ração........

9 Ganho de peso semanal médio (g/ave/semana).

Peso corporal médio (g), por ave, obtidos na 5ạ semana de idade, com separação de sexo $\left(R_{1}\right.$ e $R_{2}=1$ a e 2 a repetições $) \ldots \ldots \ldots \ldots$

Conversão alimentar semanal média ( $\mathrm{kg}$ de ra ção consumida/kg ganho pesol............

13 Peso corporal médio (g), por ave, obtidos na 7ạ semana de idade, com separação de sexo $\left(R_{1}\right.$ e $R_{2}=1$ a e 2 a repetições $) \ldots \ldots \ldots \ldots$

14 Peso corporal médio $(\mathrm{g})$, por ave, machos e fêmeas, para 5ạ e 7ạ semana de idade $\left(R_{1}\right.$ e $\mathrm{R}_{2}=1$ a e 2 a repetições) $\ldots \ldots \ldots \ldots \ldots \ldots \ldots$

15 Ordem de mérito, relativo a peso corporal, obtidas semanalmente, de acordo com a Tabe-

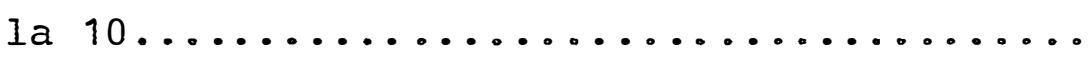

16 Análise de variāncia do peso vivo médio na fase inicial (0-35 dias) e fase final (36-

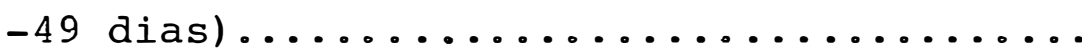


17 Número de machos e fêmeas na 7ạ semana de

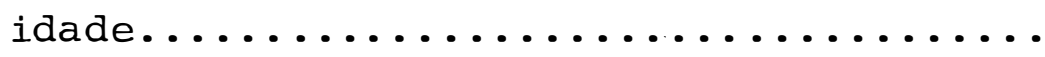

Conversão alimentar média (kg de ração $\infty$ nsumida/kg ganho pesol, para 5à e 7å sema-

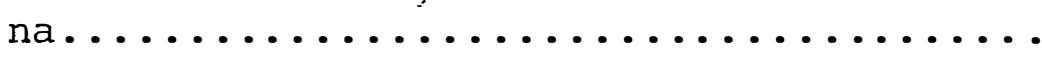

19 Anālise de variāncia para conversão ..alimentar média na fase inicial (0-35 dias) e fase final (36-49 dias).............

20 Ordem de mérito, relativo a peso corporal e conversão alimentar na 6 a e 7 semana de idade........................

Viabilidade (\%) para a 6ạ e 7ạ semana de idade........................

23 Desempenho das populações e híbridos comerciais de 0 a 49 dias..............

Peso vivo das aves utilizadas na avaliação das características de carcaça e gordura abdominal................... 
29 Porcentagem de gordura abdominal em relação ao peso eviscerado..............

30 Porcentagem de gordura abdominal em relação ao peso vivo....................

31 Rendimento de carcaça $(\%) \ldots . . \ldots \ldots \ldots$

32 Peso vivo (PV), peso sem penas (PSP), peso da carcaça (PC), peso das vísceras comestiveis (PVC) e peso da gordura abdominal $(P G)$, em gramas.................

33 Porcentagem de gordura abdomịnal em relação ao peso vivo e peso eviscerado e, ren dimento de carcaça.................

34 Análise de variāncia e coeficiente de variação para rendimento de carcaça (RC), gordura abdominal (GA) e porcentagem de gordura em relação ao peso vivo (PGV) e, peso eviscerado $(\mathrm{PE}) \ldots \ldots \ldots \ldots \ldots \ldots \ldots$

35 Coeficiente de correlação $(r)$ e equação de regressão (ER) para características de carcaça...................... 
.xii.

\section{LISTA DE FIGURAS}

Figura.

Página

1

Sumário de herdabilidade obtida em 176 publicações, para peso corporal entre a 6 a e 12a semana de idade.............. 24

2 Croqui do galpão experimental........ 38

Consumo semanal de ração, por ave.....

Ganho de peso semanal, por ave.........

5

Peso corporal semanal, por ave..........

Curva de crescimento obtida para as maio res e menores médias de peso corporal, in dependentemente do genótipo...........

7. Conversão alimentar (kg ração consumida/ /kg ganho de pesol................. 


\title{
AVALIAÇ̃̃O DE POPULAÇÕES E HÍBRIDOS DE GALINHAS \\ PARA CORTE QUANTO À TAXA DE CRESCIMENTO \\ E CARACTERÍSTICAS DE CARCACA
}

GILBERTO SILBER SCHMIDT

\author{
ORIENTADOR : \\ RANDOLFO WILLIAM SILVESTRE CUSTÓDIO
}

\section{RESUMO}

A finalidade desta pesquisa foi avaliar o desem penho quanto à taxa de crescimento, rendimento de carcaçà e de posição de gordura de sete populações de galinhas melhoradas para corte (LT, LM, LF, A, B, IP e EG), do Departamento de Genética da ESALQ/USP, comparando-as com matrizes comerciais (Ross$-\mathrm{HC}_{1}$ e Hubbard-HC ${ }_{2}$ ), a fim de se conhecer o real valor comer cial das populações. Foram utilizadas um total de 1080 aves, criadas sobre "cama" de cavaco de madeira, com um delineamento inteiramente casualizado, com 9 tratamentos (genótipos) e 2 repetições, com 60 aves por parcela, sem separação de sexo. Aos 49 dias, foram retiradas 3 aves de cada sexo, dos genọtipos $\mathrm{HC}_{1}$, IP, EG e LT, para avaliação de rendimento de carcaça e gordura abdominal. Os resultados obtidos neste trabalho possibilitam apresentar as seguiintes conclusões: 
1. As populações de síntese mais antiga (LT, LM e LF) não conseguiram manter a competitividade, em relação aos híbridos comerciais. Ficou evidente que as intensidades de seleção empregadas não foram suficientes para manter a competitividade destas populações.

2. As populações de sintese mais recente (A e B) apresentaram resultados inferiores aos híbridos comerciais e aos materiais IP e EG.

3. Os genótipos IP e EG apresentaram um desempenho muito promissor, indicando um grande potencial como matéria-prima pa, ra a sintese de novas populações a serem utilizadas no programa de melhoramento.

4. A população LT apresentou um baixo rendimento de carcaça, em comparação com os demais materiais utilizados.

5. As feemeas apresentaram um maior rendimento de carcaça e um maior acúmulo de gordura abdominal.

6. Os genótipos não apresentaram dịferenças quanto à porcentagem de gordura abdominal, expressa em relação ao peso vivo e peso eviscerado, contudo, quando a avaliação foi feita em função da quantidade de gordura aderida à carcaça, a popula ção LT apresentou uma maior deposição. 
7. A deposição de gordura abdominal não apresentou uma correla ção expressiva com o peso vivo e peso da carcaça eviscerada, sendo que os respectivos coeficientes de correlação foram iguais a $-0,01$ e 0,11 .

8. O peso eviscerado e peso sem penas apresentaram uma àlta correlação com o peso vivo, sendo os coeficientes de correlação iguais a 0,997 e 0,970 , respectivamente. 
.xví.

\title{
RATE OF GROWTH AND CARCASS TRAITS IMPROVED POPULATIONS AND HYBRIDS OF MEAT TYPE CHICKENS
}

\author{
GILBERTO SILBER SCHMIDT \\ - AUTHOR -
}

\section{RANDOLFO WILLIAM SILVESTRE CUSTÓDIO - ADVISER -}

\section{SUMMARY}

The experiment was carried out. in facilities belonging to Department of.Genetics, College of Agriculture "Luiz de Queiroz", University of State of São Paulo, Iocated in Piracicaba City, State of São Paulo, Brazil. Growth rate, dressing percentage and abdominal fat deposition were evaluated in nine broiler populations; seve of these populations designated by LT, LM, LF, A, B, IP and EG were developed at the Department of Genética, and two were commercial lines, Ros's $\left(\mathrm{HC}_{1}\right)$ and Hubbard $\left(\mathrm{HC}_{2}\right)$. Each of the nine lines were replicated twice, at random, each pen including 60 broilers without sexing. At 49 . days from each sex of the lines $\mathrm{HC}_{1}$, IP, EG and LT a sample of 3 broilers was taken according the body weight (the heaviest, intermedial and the lightest) in order to evaluate dressing percentage and abdominal fat. 
The results of growth rate and feed efficiency indicated that the older populations, LT, LM and LF idid not compete with commercial lines. It appears that the intensity of selection applied was not enough to maintain competitivity in these lines. Same results were observed in lines. A and B. However, the genotypes IP and EG could be considered as genetic material with great potential for the synthesis of new broiler populations.

There were no differences among lines with respect to abdominal fat expressed as a percentage of body weight and carcass weight. However, line LT presented more fat, than other lines. Overall, females had great dressing percentage and more abdominal fat than males. 


\section{INTRODUÇÃO}

Dentre as atividades da pecuária, a avicultura vem se desenvolvendo nestes últimos anos em grandes proporçoes. Tal desenvolvimento foi atingido, principalmente, devido aos conhecimentos em genética, nutrição, manejo e sanidade, adqui . ridos nos últimos anos. Estes conhecimentos fizeram com que o desempenho do frango evoluisse de maneira assustadora, aumentando consideravelmente a taxa de crescimento e eficiência alimentar. Em 1977 o Brasil ocupou mundialmente o $6 \%$ e o 10 \% lugar, respectivamente, na produção de frango de corte e ovos, alcançando um $2 \%$ posto na área de corte em 1980. Entretanto, o Brasil é totalmente dependente da importação de mate riais genéticos básicos para a produção de pintos de um dia.

Visando preencher esta lacuna, vem se desenvol 
vendo, desde 1973, no Departamento de Genética da ¿̇scola Superior de Agricultura "Luiz de Queiróz"., da Universidade . ¿de São Paulo, Piracicaba, um programa de melhoramento genétioo de galinhas para corte, tendo por objetivo pesquisar e obter populações melhoradas a partir de avós, matrizes e híbridos comerciais. A partir de 1973, duas populações. (LT e LM) foram sintetizadas através: de intercruzamentos de populações e matrí zes para corte, sendo que estas passaram por intensa sele ção para aumento de taxa de crescimento e menor intensida de de seleção para taxa reprodutiva. Em 1975 a população LT foi introduzida nos trabalhos de pesquisa e melhoramen to, passando a ser conduzida de maneira análoga às de mais populações.

\section{Para o melhoramento da taxa de crescimento}

tem-se utilizado a seleção massal ou seleção fenotípica dosin divíduos, sendo que o crescimento rápido tem importância funa amental do ponto de vista econômico, pois paralelamente, a conversão alimentar é melhorada.

objetivando comparar os desempenhos das popula ções selecionad́as ( $L \Gamma$, LM e LF) com materiais genéticos importados, düas outras populações-foram sintetizadas, uma pop̣u lação de Inatrizes fêmea (B) e outra de matrizes macho (A), que foram incluídas nas pesquisas de genética e melhoramento. COS 'זA e CUșTódio (1979) e sCHMIDT e CUSTÓdio (1980), através de testes efetuados com estes materiais (LT, LiI, LF, A e B), verificaram que seria de suma importância, do ponto de vista prá 
tico, conhecer as características e comparar o desempenho de matrizes macho. (A X LM e LT X A) e matrizes fêmea (LM X LT e LT X LM), sendo que os resultados mostraram-se muito promisso res. SCHuID'T et alii (1981) verificaram que as populações selecionadas mantiveram-se competitivas, em relação ass mateiriais de origem mais recente.

Mais recentemente, foram obtidas quatro linhagens de avós para corte denominadas de I (macho da linha de macho), $\mathrm{P}$ (fêmea da linha de macho), E (macho da linha de fêmea) e G (fêmea da linha de fêmea), que em testes prelimina res mostraram resultados altamente promissores.

$\therefore \bar{E}$ fundamental para a indústria o fornecimento de carcaças de alta qualidade ao consumidor. Atualmente, uma das grandes preocupações dos melhoristas, principalmente em países da Europa e Estados Unidos, cujo comércio é muito exigente quanto à qualidade da carcaça, reside na redução de gor dura abåminal, visando a diminuição dos prejuízos da inaústria, consumidor e produtor, sendo que para este "ültimo, o maior acúmulo de gordura implica em uma pior conversão alimen tar, pois a síntese da proteína é muito mais eficiente que a síntese de gordura.

Assim sendo, este trabalho foi desenvolvido paㅡ ra avaliar não somente a taxa de crescimento, como também o rendimento de carcaça e a deposição de gordura abdominal, dos materiais genéticos mantidos no Departamento de Genética da 
Escola Superior de Agricultura "Luiz de Queirọz", da Universí dade de São Paulo (LT, LM, LF, A, B, IP e EG), comparando-os com matrizes comerciais, a fim de se conhecer o valor comercial de cada uma. 


\section{REVISÃO DE LITERATURA}

\subsection{TAXA DE CRESCIMENTO}

A taxa de crescimento é medida através do peso juvenil, que assume um papel muito importante na aceitação de uma linhagem comercial. Segundo MALONE et alii (1979) vários experimentos foram conduzidos com a finalidade de comparar o desempenho de diferentes linhagens ou, cruzamentos entre linhagens de frangos de corte. A maioria dos trabalhos conduzidos neste sentido (CAMPOs, 1975; FARR et alii, 1977; MALOINE et alii, 1979; GROOM e PEARSON, 1980 ; CAVALHEIRO et alii, 1982), demonstrou uma diferença entre as linhagens comerciais em relação à taxa de crescimento e outras características de impor tância econômica. ABREU et alii (1982a) verificaram diferenças significativas para ganho de peso médio e conversão "alimentar entre e dentro do sexo, quando compararam quatro linhagens comerciais. Na Tabela 1 verifica-se o desempenho de 
linhagens comerciais, para características de interesse econô mico.

Os ganhos por meio de seleção para peso 'corporal na 8ạ semana de idade são muito pequenos em linhagens já com altos níveis de intensidade de seleção para crescimento, Esta diminuição da resposta não pode ser atribuida ao cruzainento ou oscilação genética. A tentativa de aumentar a variabilidade genética, através de retrocruzamento com .ancestrais, não provoca melhoria. o progresso por meiollde seleção parece ser mais rápido quando esta é iniciada em linhagens com inten sidade de crescimento pior do que seus ancestrais. A intensidade de crescimento de uma linhagem panmítica é mais severamente deprimida por severos "stress" do que outras Iinhagens (JAAP, 1963) .

CUSTÓDIO e PACKER(1976). através de.seis ensaios concluiram que as populaçōes LT, LM e LF e seus híbridos, apresentavam em termos de taxa de crescimento a seguinte ordem decrescente: LT, LF x LT, LT x LM, LM, LM x LF, LF, sendo que os híbridos LıI x LF e LT x LM não demonstraram efeitos heteró ticos.

Através de cruzaméntos dialélicos incomplètos, CUSTÓDIO e ZABOROWSKY (1977) verificaram que os melhores desempenhos foram apresentados pelos cruzamentos LiV X LT $(1.680 \pm$ $\pm 26 \mathrm{~g})$ e LF $\mathrm{L} \operatorname{LM}(1.662 \pm 20 \mathrm{~g})$, havendo evidēncias de efeitos recíprocos entre os cruzamentos LT com LM e LF: com, IM. Quando se compara estes resultados com as taxas reprodutivas 


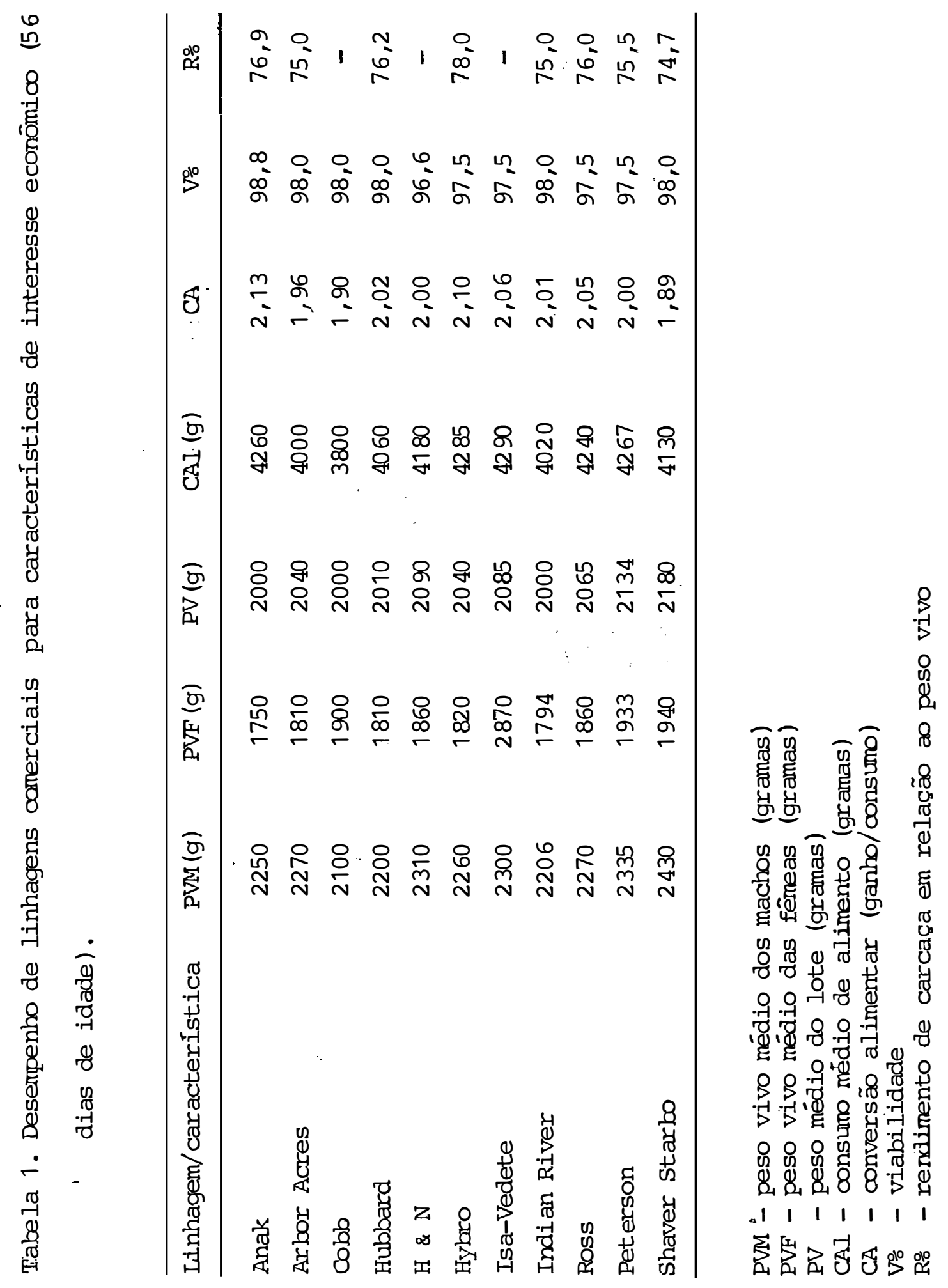


das galinhas que deram origem a estes progênies, verifica-se que nem sempre o cruzamento de melhor desempenho para taxa re produtiva também apresenta progênie de melhor taxa de crescimento. Quando se considera, ao mesmo tempo, as taxas de cresci mento e reprodutiva, o cruzamento LF $x$ LM parece ser 0 mais conveniente. Estes resultados parecem indicar que o peso vivo total produzido por cruzamento poderá ser um critério mais adequado, . do ponto de vista prático, do que a consideração separada dos caracteres que o influenciaram.

As populações LF e LT vêm sendo submetidas a seleção mais intensa que a população LM. Apesar disso, o peso médio das populações LM e LF tem aumentado paralelamente entre si, porém, as alterações provocadas pela seleção tem sido menores na população LT (CUSTÓDIO, 1978). ZABOROWSKY et alli (1977) observaram que as populações LF e LM apresentaram taxas de crescimento semelhante, porém, o peso médio da população LF era significativamente menor (cerca de 37 gramas).

COSTA e CUSTÓDIO (1979); SCHMIDT e CUSTÓDIO

(1980) baseados nas taxas reprodutivas e de crescimento, fr testes de hibridização efetuados com as populações LM, LF, LT, A e $\dot{B}$, verificaram que, do ponto dé vista prático, seria de gran de importāncia conhecer as características e comparar os os de sempenhos das matrizes de macho (A $x$ Li e LT $x$ A) e matrizes de fênea (LM x LT e LT x LM). Os resultados obtidos para es- 
tes cruzamentos são apresentados. por SCHMIDṬ et alii (1981).

\subsection{GORDURA ABDOMINAL}

A deposição de gorduraabdominal é influenciała por fatores genéticos e ambientais (CHErRRY et alii, 1978). Vạ rios são os fatores ambientais, sendo que, muitos destes, já foram amplamente pesquisalos, como: nutrição, idade, sexo, es tações do: ano e controle de iluminação (LIN et alii, 1980).

Os fatores nutricionais for am revisados por NEL SON (1980) e são incluídos: relação energia/proteína, gordura da dieta, restrição de nutrientes e níveis de proteína. A manipulação lesses fatores muitas vezes resulta no deckéscimo do peso corporal, em maior escala, que a perda da gordura. A res trição energética durante a fase final de crescimento tem se mostrado uma medida prática para reduzir a gordura abdominal sem acarretar em perdas significativas na eficiência alimentar e ganho de peso (ARAFA et alii, 1983).

Parece existir um consenso entre os pes yuisado res de que, a medida que se diminui o teor de proteína e se e leva o de energia na dieta, ocorre um aumento na deposição de gordura abdominal e que, para diminuí-la o inverso é verdadei ro (DAINSKY e HILL, 1952; ISLABÃO, 1970 ; LIN et alii, 1980; BRE NES et alii, 1983). FARR et alii, 1977 realizaram dois experi mentos comparando sete linhagens comerciais de frango de corte submetidos à dietas com 3 níveis de energia $(3080,3190$ e 
$3300 \mathrm{kcal} / \mathrm{kg})$, observando diferenças entre linhagens e uma re lação linear entre nível de energia da dieta e deposição de g orduras.

O aumento do nível de proteína da raçao, na fạ se final de crescimento (29 a 49 dias) afeta positivamente o rendimento de carcaça, porem, o mesmo aumento em uma ração iso calórica, determina um maior acúmulo de gordura abdominal, sen do que, para os níveis 20,18 e 16\%, os teores de gordura são, respectivamente, iguais a 1,98, 2,30 e 2,57\% (ABREU et alii, $1982 \mathrm{~b})$. Os mesmos resultados foram obtidos por ISLABÃO (1970). Outros estudos tem indicado que dietas desequilibradas em pro teína, ou em aminoácidas, em relação ao nível energético, tein grande responsabilidade no aumento da deposição de gordura na carcaça (HILL e DANSKY, 1954 ).

Ẻn relação ao sexo, parece evidente que as fêmeas apresentam uma maior tendência a acumular gordura (ISLABÃo; 1970; KUBEMA et alii, 1974; BECKËR et alii, 1979, GOODWIN 1980: MERKLEY et alii, 1980; MENDES et alii, 1981). Entretanto DEATON et alii (1974) verificaram que os machos apresentam 15\% mais gordura que as fêmeas, em relação ao peso vivo. ISLA BÃO (1970) constatou que as fêmeas depositam, em média, 11,2\% de gordura a mais que os machos.

Para GOODWIN (1980) a maior porcentagem de gor aura apresentada pelas fēmeas estaria relacionada com fatores hormonais, citando que, caso o macho seja castrado, ele pode- 
ria vir a ter um maior acúmulo de gordura que as fêmeas, a exemplo do que ocorre com os bovinos. Segundo IRWIN "et alii (1943); TURNER et alii (1944); WHEELER et alii (1948); BOONE et alii (1950); OLOUFA (1955); HEBER'I' e BRUNSO! (1957) e WILsoiv et alii (1983) a atividade da tiróide apresenta influência sobre a disposição da gordura.

KUBEMA et alii (1974) levantarain a hipótese de que o maior acúmulo, de gordura pelas fêmeas possa ser deví do às diferenças na curva de crescimento de machos e fêmeas ou, então, devido às diferenças metabólicas.

CAVE (1981) observou que aos 48 dias apenas as fêmeas eram afetadas por um programa de luz intermitente, enquanto que, aos 56 dias, tanto machos como fêmeas apresentavam menor acúmulo de gordura, em comparação com o progrạma de luz contínua. Isso levou o autor a concluir que o uso de luz intermitente ( 1 hora de luz seguida de 3 horaside escuro), po de ser uma maneira prática de reduzir a gordura abdominal.

Quando se efetua a seleção de diferentes carac terísticas como por exemplo, linha para maior ganho de peso, linha para maior consumo e linha para menor conversão alimentar, verifica-se que o maior volume de células adiposas ocorre nas linhas selecionadas para maior ganho de peso e maior consumo, sendo que, isto ocorre em decorrência da maior taxa de crescimento destas linhas (HOOD et alii, 1981).

SCHARWTZEBERG et alii (1981) compararam machos 
e fêmeas de 6 linhagens comerciais de frango aos 43; 50 e 57 dias de idade, encontrando um efeito de linhagem e de idade de abate na deposição de gordura abdominal. LITTLEFIELD (1972) obteve resultados semelhantes, ressaltando também, que a linhagem que apresentou maior porcentagem de gordura teve a pior conversão alimentar. A diferença entre linhagens também foi ressaltada por GODWIN (1980).

MERKLEY et alii (1981) utilizaram 21 mil frangos, em. 4 experimentos (um em cada estação do ano), provenien tes de cinco linhagens. Machos e fêmeas foram criados com separação de sexo. As aves foram abatidas com 57 dias de idade e, diferenças quanto a quantidade de gordura abdominal, aderi da à carcaça, foram encontradas entre os cruzamentos, sexo e estações do ano. Temperaturas ambientais elevadas provocam au mento nessa deposição, tanto para machos como para fêmeas (KU BEMA et alii, 1974).

Muitos resultados de pesquisas demonstram que o excesso de gordura abdominal ocorre em função da seleção pa ra maiores taxas de crescimento, ou, de peso corporal, nas aves (RICHARD e ROUVIER, 1967 e 1969; PROUDMAN et alii, 1970; WETHLI e WESSELS, 1973 e BECKER, 1978). Segundo LEESON e SUMMERS (1980) a gordura abdominal representa aproximadamente 3,5\% do peso corporal. A seleção para melhorar a conversão : a limentar eleva o acúmulo da gordura abdominal (PALMER et alii, 1946). BECKER et alii (1978) sugerem que a seleção contra gordura abdominal possivelmente resulte no decréscimo da gordu- 
ra total da carcaça.

Segundo LIN (1981) a seleção para maior peso corporal ou maior velocidade de crescimento resulta em um aumento na deposição de gordura pelas seguintes razões:

- O animal apresenta pouca capacidade de armazenar excedentes de carboidratos e proteínas, considerando que tenha tecido adiposo para armazenar energia extra;

- Tanto o carboidrato como a proteína são convertidos para gordura, porém, o inverso não ocorre;

- o controle genético da síntese de proteína é mais complicado que o da sintese de gordura, assim, fica mais difícil a manipulação da sintese de proteína;

- A seleção para a rápida velocidade de crescí mento tem resultado no aumento na deposição, que 'é acumulada na forma de gordura quando o crescimento muscular e requerimentos de mantença e produção são satisfeitos;

- Uma constante produção de gordura, proteína, minerais e água assume papel importante nas células musculares, sugerindo que alguma tentativa de reduzir o conteúdo gra xo nestas células poderá ser prejudicial ao animal. Aúnica op ção seria a seleção de indivíduos com a finalidade de reduzir a deposição de gordura abdominal e, conseqüentemente, reduzir a gordura total da carcaça. 


\subsection{RENDIMENTO DE CARCACA}

A alguns anos atrás, a classificação e tipificação de carcaça não tinha a importância comercial, hoje exigida. As causas dessas mudanças são inúmeras, porém as princị pais, destaca-se o aumento de oferta e demanda de carne de aves nas últimas décadas e, também a exigência de alguns países importadores, como é o caso do Oriente Médio, que exige aves com menor peso, porém, com boa conformação de carçaça. Estes fatos demandaram uma melhoria na qualidade das carcaças comercializadas, devido à exigência do consumidor, que passou a poder escolher as carcaças de melhor qualidade.

SILVA et alii (1972) verificaram a seguinte composição bromatológica para carcaça: $61,83 \pm 0,3 \%$ de umidade; $15,88 \pm 0,11 \%$ de proteína; $41,97 \pm 0,62 \%$ de proteína na matéria se ca; $21,94 \pm 0,49 \%$ de gordura; $57,07 \pm 0,74 \%$ de gordura na matéria seca. A relação umidade/proteína foi de $3,90 \pm 0,02$.

Através da tabela 2, podemos verificar os rendimentos percentuais das várias partes, em relação ao peso vị vo e peso da carcaça eviscerada de machos e fêmeas (CAMPos e CHQUILOFF, 1966).

Muitos trabalhos de pesquisa demonstraram a existência de diferenças significativas, quanto ao rendimento da carcaça, entre as linhagens comerciais (HATHAWAY et alii, 1953; ORR, 1955; CAMPOS E CHQUILOFF, 1966; RANGANATHAN et alii, 1967; MALONE et alii, 1979 e PEZZATO et alii, 1981). GHION 
(1979) e MALONE et alii (1979) verificaram diferenças entre sexos, sendo que as fêmeas apresentavam maior rendimento de peito e dorso, enquanto que os machos, apresentavam maior ren dimento de pernas. Quanto ao sexo, os resultados são : conflitantes, uma vez que, enquanto MORAN Jr. e ORR (1969) encontraram maior rendimento de carcaça eviscerada para machos, TADLE et alii (1955) e MORAN Jr. (1980) observaram o inverso. Já ORR (1955) e AFIFI e RASHEED (1966) não encontraram diferenças en tre sexos..De acordo com EDWARDS (1971), além da linhagem e se xo, a relação proteína/energia da dieta constitui um fator sobre a composição e rendimento da carcaça.

Utilizando-se de 5 linhagens comerciais, ABRAM e GOODWIN (1977), verificaram diferenças significativas entre linhagens para peso do peito, costela, coxa e asas, em relação ao peso corporal, sendo que, aves com alto peso, apresentavam um maior comprimento de canela e quilha. As aves de pesos maiores não apresentavam, necessariamente, um maior rendi mento. O peso eviscerado, peso das partes, rendimento de coxa (em porcentagem do peso da carcaça) e comprimento da carcaça, foram altamente significativos nos machos, sendo que estes apresentavam uma maior variabilidade em termos de carcaça.

BOWNKAMP et alii (1973) estudaram a influência no rendimento das partes, no cruzamento de Hubbard x Arbor Acres e Vantress x Arbor Acres, verificando maior rendimento do peito e costela, e um menor rendimento para asas e per- 
nas, quando se utilizava o Hubbard. SINGH e ESSARY (1974) en contraram diferenças significativas no rendimento de carcaça, em função da idade de abate.

ABPLANALP et alii (1960) utilizaram um indice de seleção para dar ganhos máximos em ângulo de peito em New Hampshire, comparando sua eficiēncia com aquela da seleção dí reta. O experimento mostrou uma vantagem no indice sobre a se leção direta, mesmo quando as condições consideradas para a construção do İndice não foram conhecidas. A superioridade re lativa do índice de seleção foi próximo ao esperado para a aplicação exata do índice.

A predição dos pesos dos principais cortes, pa ra a classificação das peças, segundo padrões previamente fixados, pode ser feita tanto em função do peso vivo da ave, cô mo em função do peso da carcaça eviscerada. O uso da carcaça para determinação dos pesos dos principais cortes $\because$ apresenta maior margem de segurança do que o uso do peso vivo (SNEDCOR, 1956) . 
Tabela 2 - Rendimento porcentual das várias partes em relação ao peso vivo e peso da' carcaça 'evisceradas. (CAMPOS e CHQUILOFF, 1966).

\begin{tabular}{|c|c|c|c|c|}
\hline \multirow{2}{*}{ Partes } & \multicolumn{2}{|c|}{ Em relação ao peso vivo } & \multicolumn{2}{|c|}{ Em relação ao peso eviscerado } \\
\hline & Machos & Fêmeas & Machos & Fêneas \\
\hline Penas e Sangue & 11,29 & 11,90 & - & - \\
\hline Cabeça & 2,78 & 2,81 & 3,85 & 3,97 \\
\hline Pés & 5,32 & 4,40 & 7,37 & 6,21 \\
\hline Pescoço & 2,48 & 2,45 & 3,44 & 3,46 \\
\hline Peito & 15,43 & 16,81 & 21,37 & 23,73 \\
\hline Coxas & 10,64 & 10,46 & 14,74 & 14,76 \\
\hline Pernas & 10,70 & 9,52 & 14,82 & 13,44 \\
\hline Asas & 8,46 & 8,44 & 11,71 & 11,91 \\
\hline Dorso & 16,38 & 15,94 & 22,69 & 22,50 \\
\hline Moela & 2,48 & 2,69 & - & - \\
\hline Fígado & 2,07 & 2,04 & - & - \\
\hline Coração & 0,58 & 0,61 & - & - \\
\hline
\end{tabular}




\subsection{COEFICIENTES DE HERDABILIDADES}

A resposta de uma população à seleção está na dependência de 3 grupos de fatores: 0 10 inclui o tipo e a in tensidade de forças seletivas; 02 \% compreende a ação e a interação dos genes ao produzirem seus efeitos e, finalmente, o 30 grupo que corresponde à quantidade e à natureza de variabí lidade da população. Ao considerar a resposta à seleção, deve-se levar em conta esses 3 grupos de fatores (MATHER, 1955).

o conhecimento destes fatores permite que se $\underline{\text { fa }}$ ça previsão a respeito da taxa de melhoramento esperada para um determinado caráter, quando uma população é submetida à uma certa pressão de seleção. Entretanto, segundo FESTING e NOR DSKOG (1967), as mudanças genéticas observadas freqüentemente mostram pouca concordância com as mudanças esperadas. Em̉ conseqüência, a boa previsão só é possível quando se tem um bom conhecimento da constituição genética das populações, das cor relações entre características selecionadas, a adaptação re-produtiva dos indivíduos e do modo como a população se aproxí ma dos limites de seleção.

A análise genética de-características de aves tem sido amplamente difundida, e as estimativas de componentes genéticos são de importância no estabelecimento de progra mas de seleção de aves mais eficientes e com menor custo de produção.

HILL (1972b) observa que são possíveis três es 
timadores da herdabilidade realizada, em experimentos de sele ção massal numa única direção, e na ausência de uma população controle: 1. regressão de resposta acumulada sobre o diferencial de seleção; 2. regressão das respostas individuais sobre os diferenciais de seleção individuais; e 3. razão da resposta total para o diferencial de seleção total. Segundo o autor, o mais adequado, para a maioria das situações práticas, é o primeiro, cuja obtenção é feita através da fórmula. proposta por FALCONER (1954). A variância da estimativa assim obtida é dada por HILL (1972a). HILL (1971), ao descrever o modelo em que se baseia seu estudo sobre estimativas de parâmetros gené ticos, a partir de experimentos de seleção, relaciona as se. guintes suposições: as variâncias e covariâncias genéticas não se alteram durante a seleção; cada gene, isoladamente, tem efeito pequeno; não há efeitos confundidores da ligação gênica e o coeficiente total de endogamia não alcança valor elevado durante a seleção.

Vários autores citados por KHAN (1972), relatam que as estimativas de herdabilidade baseadas na correla ção entre parentes e os resultados obtidos nos experimentos de seleção revelam que os efeitos genéticos aditivos são importantes na determinação de variabilidade de peso juvenil. A va riação genética aditiva responde por aproximadamente $30 \%$ da va riação total, para peso corporal, quando se compara populações que receberam seleções individuais em direções divergen- 
tes. Desvios epistáticos parecem ser sem importāncia. Os papéis dos efeitos de dominânciae maternos na herança do peso corporal na oitava semana de idade foram discutidos por YAO (1959, 1961) e SIEGEL (1962).

Estimativas da variāncia genética não aditivas podem ser obtidas pela comparação dos componentes da váriância obtida na análise de acasalamentos hierárquicos. Porém,es sas estimativas podem ser tendenciosas devido aos efeitos maternos, e aos genes ligados ao sexo. A diferença entre os com ponentes dos pais e das mães geralmentè é pequena (GOODMAN e GODFREY, 1956; SIEGEL, 1962; KINNEY e SHOFFNER, 1965; MARKS e SIEGEL, 1971).

Através da análise de cruzamentos dialélicos também pode-se obter estimativas da variância genética não aditiva. A maior parte da interação pai x mãe é devida à fração genética não aditiva. Os efeitos gênicos não aditivos se constituem em fator importante na determinação do peso juvenil em galinhas (SMITH, 1957; JAAP et alii, $1962 ; \mathrm{FRENCH}_{n} 1971$. Também a heterose para taxa de crescimento é comum em galinhas MORLEY, 1958; HILL e NORDSKOG, 1958 e KHAN et alii, 1958). Na maioria dos casos, os dados utiłizados foram obtidos do cruzamento de galinhas especializadas na produção de ovos.

O peso corporal na 8ă semana de idade é uma ca racterística quantitativa influênciada por um complexo mecanismo fisiológico. ASMUNDSON e LERNER (1933) demonstraram que 
diferenças herdadas para peso corporal são influenciadas por múltiplos fatores genéticos. JAAP e MORRIS (1937) tentaram de terminar quantitativamente a importância relativa das fontes de variação para peso corporal na oitava semana de idade. DEV et alii (1969) compararam a herdabilidade obtida da correlação entre parentes com a realizada. As duas estimativas pouco diferiram. SIEGEL (1962) e KINNEY e SHOFFNER (1967) relatam a concordância entre estimativas de herdabilidade calculada e realizada para peso corporal na oitava semana de idade. Desta maneira, parece ser justificável, segundo esses autores, o uso das estimativas de herdabilidade para pre dịção do progresso genético a ser obtido por seleção massal, no decorrer de 10 gerações, aproximadamente. Experimentos de seleção podem, pois, fornecer estimativas da herdabilidade e de sua variância, tão necessária para compreensão dos resultą dos obtidos.

A média das diversas estimativas de herdabilidade constantes na literatura, para peso corporal ao fim de 8 semanas é 0,26, por outro lado, há evidências de que a variância genética não aditiva, em galinhas, também tem certa impor tância na determinação do peso corporal nas fases iniciais da vida (MARTIN et alii, 1953; BRUNSON et alii, 1956; GOODMAN e JAAP , 1957 e 1960; KHAN, 1972).

Os resultados experimentais indicam que, em mé dia, é perguena a variação nas estimativas de herdabilidade pạ 
ra peso corporal na 4 a semana e em idades posteriores. Embora algumas estimativas de herdabilidade baseadas nós componentes de reprodutor e fẽmea dentro de reprodutor, indiquem a exis-tência de efeitos maternos e/ou de dominância na expressão des sas características; as médias de várias estimativas indicam que esses efeitos não são importantes (KIN Stima da herdabilidade para peso corporal em várias idades tem sido relatadas por vários autores. GOODMAN e GOLDFREY (1956); SIEGEL, 1963; FESTING e NORDSKOG (1967); MIEILLI et alii (1981), obtiveram, respectivamente, as seguintes estimativas da herdabilidade para peso corporal na oitava semana de idade, 0,$30 ; 0,35 ; 0,26 ; 0,26$ (para machos) e 0,14 (para fêmeas); 0,38 (para machos) e 0,30 (para fêreas). ZABOROWSKI et alii (1977) estimaram a herdabilidade de 3 popu lações de galinhas melhoradas para corte: LT, LM e LF; sendo estas respectivamente iguais a $0,349 \pm 0,106,0,155 \pm 0,077$ e $0,181 \pm 0,64$

Um sumário de 176 publicações sobre herdabilidade estimada para peso corporal obtidos de 6 a 12 semanassão apresentadas na Figura -1. Esta revisão indica que, na maioria das populações estudadas, o peso córporal nessas idades apresen tam herdabilidade de moderada para alta. A herdabilidade médias foi de 0,41 em intervalo entre 0,29 e 0,54 (SIEGEL,1962). A herdabilidade para deposição de gordura abdọ minal apresenta-se superior a 0,50 (GOODWIN, 1980). A herdabi lidade para ângulo de peito na 12a semana (LERNER et alii,1947) 
na 9ạ semana (GODFREY e GOODMAN, 1956) e, na 10å semana (BRUN SON et alii, 1956 e COOKE et alii, 1956) são, respectivamente, iguais a 0,$20 ; 0,50$ e 0,30 .

A herdabilidade baseada em correlações entre irmão é, em média, 0,60 para comprimento de coxa e comprimento de quilha, enquanto: que para profundidade de corpo e ângu-lo do peito os valores são menores (MCCARTNEY, 1961).

FRIARS et alii (1983) através de acasalamentos hierárquicos verificaram que a herdabilidade para gordura ab.dominal, gordura abdominal em relação ao peso da carcaça e por centagem de gordura abdominal da carcaça $(0,51 ; 0,62$ e 0,48 , respectivamente), se mostraram superiores à herdabilidade para ganho diário $(0,26)$, conversão alimentar $(0,26)$ e peso vivo $(0,30)$. 


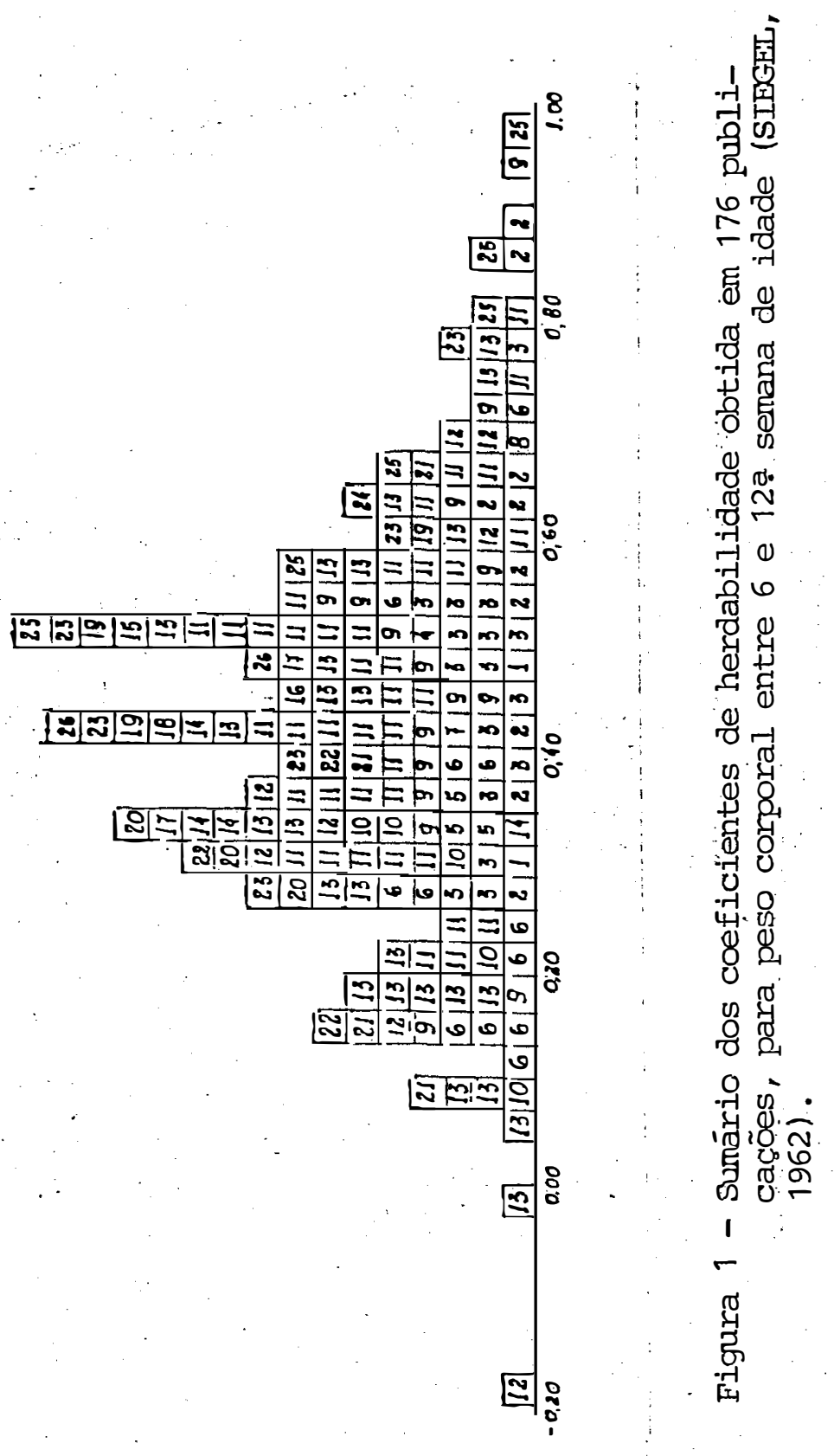




\subsection{CORRELACõES GENÉTICAS, FENOTÍPICAS E AMBIENTAIS}

Às, vezes, as exigências de mercado causam embaraços, desejando associaçõés de caracteres negativamente:cor relacionados do ponto de vista genético ou o contrário. Assim, peso do corpo e comprimento de canela são positivamente corre lacionados, mas o mercado deseja aves de perna curta e grande peso corporal. Peso do ovo e produção tem associação negativa, mas o criador deseja ambos altos.

Estudos de correlação genética entre vários ca racteres foram realizados no Texas, mostrando, felizmente, al tas e positivas correlações entre vários caracteres, como por exemplo: carneamento e largura do peito $(0,80)$; peso e classi ficação final de mercado $(0,73)$. Algumas foram negativas, como peso do corpo e fertilidade $(-0,1)$ e comprimento de canela e taxa reprodutiva (cópula). Tais conhecimentos são úteis no preparo de melhoramento e especialmente para estruturação de indices de seleção (BRIQUET, 1967).

WALTERS et alii (1963), citados por ABRAM e GOOD-. WIN (1977);, estudaram as relações das principais partes do frango de corte com a carcaça, concluindo que os pesos, volumes e as dimensões dos cortes sãó estritamente correlacionados com o peso da carcaça. Desta forma, tanto o peso quanto o volume e as dimensões das partes do frango de corte podem ser conhecidos, com razoável segurança, através da simples pesagem da carcaça eviscerada. 
O peso corporal na 8ạ, 16ạ e 24ạ semana de ida de são altamente corrélacionados genética e fenotipicamente. Quase todas as correlações de conformação são positivas, exce to comprimento da coxa e profundidade de corpo e, entre peso do corpo e ângulo do peito (MCCARTNEY, 1961).

Quando se avalia linhagens, verifica-se a exis tência de diferenças em termos de rendimento de carcaça. O ren dimento do peito, costelas, asas e coxas em relação ao peso vivo difere entre linhagens. Aves com alto peso apresentam com primento de quilha e canela significativamente mais alto, porém, não necessariamente maiores rendimentos de carcaça. O pe so eviscerado, peso das partes e mensuração linear:(comprimen to) apresentam diferenças mais acentuadas entre os machos (ABRAM E GOODWIN, 1977).

Existe uma correlação positiva entre tamanho do corpo e rendimento eviscerado, mas não existe correlação entre plumagem e rendimento (JAAP et alii, 1950). Os valores de 0,$13 ; 0,10$ e 0,16 , respectivamente, para correlações fenotípi cas, genéticas e ambientais, foram encontrados por LERNER et alii (1947) entre peso vivo é ângulo de peito na 12a semana de idade. GOLDFREY e GOODMAN (1956)'obtiveram correlações fenotí picas, genotípicas e ambientais de 0,$30 ; 0,50$ e 0,30 , respectivamente, entre peso vivo e ângulo de peito na 9ạ semana de idade. CoOKE et alii (1956) verificaram a correlação fenotípi ca de 0,26 entre peso vivo e ângulo de peito na 10ạ semana. 
FRIARS et alii (1983), através de acasalamentos hierárquicos, estimaram as correlações genéticạs e fenotí picas entre fonte de alimento e ganho diário $(0,74 \pm 0,14$ e 0,73 \pm $\pm 0,02)$, fonte de alimento e porcentagem de gordura abdominal $(0,15 \pm 0,20$ e $0,39 \pm 0,04)$, ganho médio diárío e o de gordura abdominal $(-0,30 \pm 0,21$ e $0,18 \pm 0,04)$ e porcentagem de gordura e porcentagem de proteína na carcaça $(-1,01 \pm 0,02$ e $-0,89 \pm 0,01)$. Através da tabela 3 , podemos verificar os coeficientes de correlações simples entre as diversas partes da carcaça (CHQUILOFF e CAMPOS, 1967). Os coeficientes de regres são obtidos mostram que o aumento de $1,0 \mathrm{~g}$ no peso das . vaves, corresponde sempre a um aumento no peso dos cortes. 0 coeficiente de maior magnitude foi o relativo ao peso do dorso $(b=$ $=0,2)$ em função de peso vivo, e, indica que o aumento de 1,0 $g$ no peso vivo, acarreta um aumento médio de $0,2 \mathrm{~g}$ no peso do dorso. O coeficiente de menor magnitude foi o referente às asas $(b=0,071)$.

AR'KOV (1977) verificou uma alta correlação.

$(0,86)$. entre peso vivo e comprimento do corpo e entre peso do corpo e largura do peito $(0,64$ a 0,83$)$. ABRAM e GOODWIN (1977) relata uma alta e positiva correlação entre peso do corpo $\ddot{e}$ e comprimento de quilha e canela, não verificando correlação en tre rendimento de carcaça e peso corporal.

SILVA et alii (1982) verificaram, através de a nádisenquimica da carcaça, uma correlação negativa, significa 
28.

Tabela 3 - Coeficiente de correlação simples $(r)$ 'para diversas partes da carcaça. (CHQULLFF e CAMPOS, 1967).

$(r)$

\begin{tabular}{ccc}
\hline Peito x coxa & 60 & 0,874 \\
x perna & 60 & 0,851 \\
x asas & 60 & 0,849 \\
x dorso & 60 & 0,834 \\
Coxas x perna & 60 & 0,928 \\
x asas & 60 & 0,916 \\
x dorso & 60 & 0,911 \\
Pernas x asa & 60 & 0,925 \\
asas x dorso & 60 & $0,849$. \\
\hline
\end{tabular}


tiva entre: teor de umidade e gordura $(r=-0,95)$, teor de proteína e gordura $(r=-0,74)$. SCHWARTZEBERG (1981), ao correla cionar fenotipicamente a gordura abdominal com o peso vivo,ob teve o valor de $r=0,774$.

ANDREWS (1979) e MAYER et alii (1962), estudaram a correlação entre a gordura ábdominal e outras características, obtendo resultados praticamente semelhantes, .sendo de 0,42 para peso vivo, 0,41 para peso eviscerado e 0,41 para total de alimento consumido. 


\section{MATERIAL E MÉTODOS}

\subsection{LOCAL, INSTALAÇÕES E EQUIPAMENTOS}

o experimento foi realizado nas instalações. do Departamento de Genética da Escola Superior de Agricultura " Luiz de Queiroz", Universidade de São Paulo, situado no município de Piracicaba, Estado de São Paulo.

o galpão experimental apresenta as seguintesdi mensões: 11,3m:de largura, 28,5m de comprimento e 2,7m de : pé direito. A cobertura é de telha francesa, com lanternim cen-tral ao longo de todo o galpão. Na área determinada a ensaios com frangos de corte, foram montadas 20 divisões (boxes), dis postes do lado esquerdo do galpão (Fig. 1). Cada divisão mede 
$2,0 \mathrm{~m} \times 3,0 \mathrm{~m}\left(6 \mathrm{~m}^{2}\right)$. A cama utilizada foi de cavaco de madeira (maravalha).

o equipamento utilizzado em cada divisão foi o seguinte: 1. (um) círculo de Eucatex de 0,60m de altura, 2.(dois) comedouros de plástico tipo bandeja, medindo 0,3 x 0,50m, utilizados até o 180 dia de idade dos pintos, quando então foram substituidos por comedouros tubulares (z) com capacidade para $25 \mathrm{~kg}$ de ração; 2 (dois) bebedouros de alumínio, tipo pres são, com capacidade para 2 (dois) litros, sobre estrado de ma deira de $0,42 \times 0,42 \mathrm{~m}$, utilizados até 130 dia, quando fóram substituidos por 2 (dois) bebedouros pendulares, e uma campânula com lâmpada infravermelha de $250 \mathrm{w}$ para aquecimento dos pintos até o 140 dia.

\subsection{DESCRIÇÃO. DOS MATERIAIS GENÉTICOS ENVOLVIDOS NO EXPERIMENTO}

Os progenitores de frango de corte são chamados geralmente de matrizes, as quais são aves melhoradas atravēs de seleção. As populações-base, sintetizadas pelo intercrü zamento entre linhagens ou populações, das quais as matrizes têm ori.gem são populações segregantes.

Apresenta-se a seguir uma breve descrição quan

' to a natureza dos materiais genéticos envolvidos no presente trabalho:

-LT - população originária de matrizes machos para corte e 
mantidas desde 1975;

LM - população originária de matrizes macho para corte, u sando-se retrocruzamento, e mantidas desde 1973;

LF - população originária de matrizes fêmea para corte, u sando-se retrocruzamento, e mantidas desde 1973;

A - população originária de matrizes macho para corte,cor respondente a gerações avançadas da matriz original,e mantidas desde 1979;

B - população originária de matrizes fêmea para corte,con respondente a gerạçoes avançadas da matriz original,e mantidas desde 1979;

IP - matrizes macho para corte, mantidas desde 1981;

EG - matrizes fêmea para corte, mantïdas desde 1981;

$\mathrm{HC}_{1}$ - matrizes para corte da linhagem comercial ROSS;

$\mathrm{HC}_{2}$ - matrizes para corte $₫$ a linhagem comercial HUBBARD.

\subsection{Manejo das aves}

O número de reprodutores utilizados nos acasalamentos, para a obtenção dos pintos experimentais é apresentada na tabela 4. Pạra a produção dos pintos, foi feita uma in cubação, com 3826 ovos, sendo que os ovos dos materiais genéticos LT, LM, LF, A e B foram obtidos através de inseminação artificial, enquanto que IP, $\mathrm{EG}, \mathrm{HC}_{1}$ e $\mathrm{HC}_{2}$, obtidos através de acasalamento natural. Os pintos passaram por um processo... de marcação através de corte e cauterização das falanges de de- 


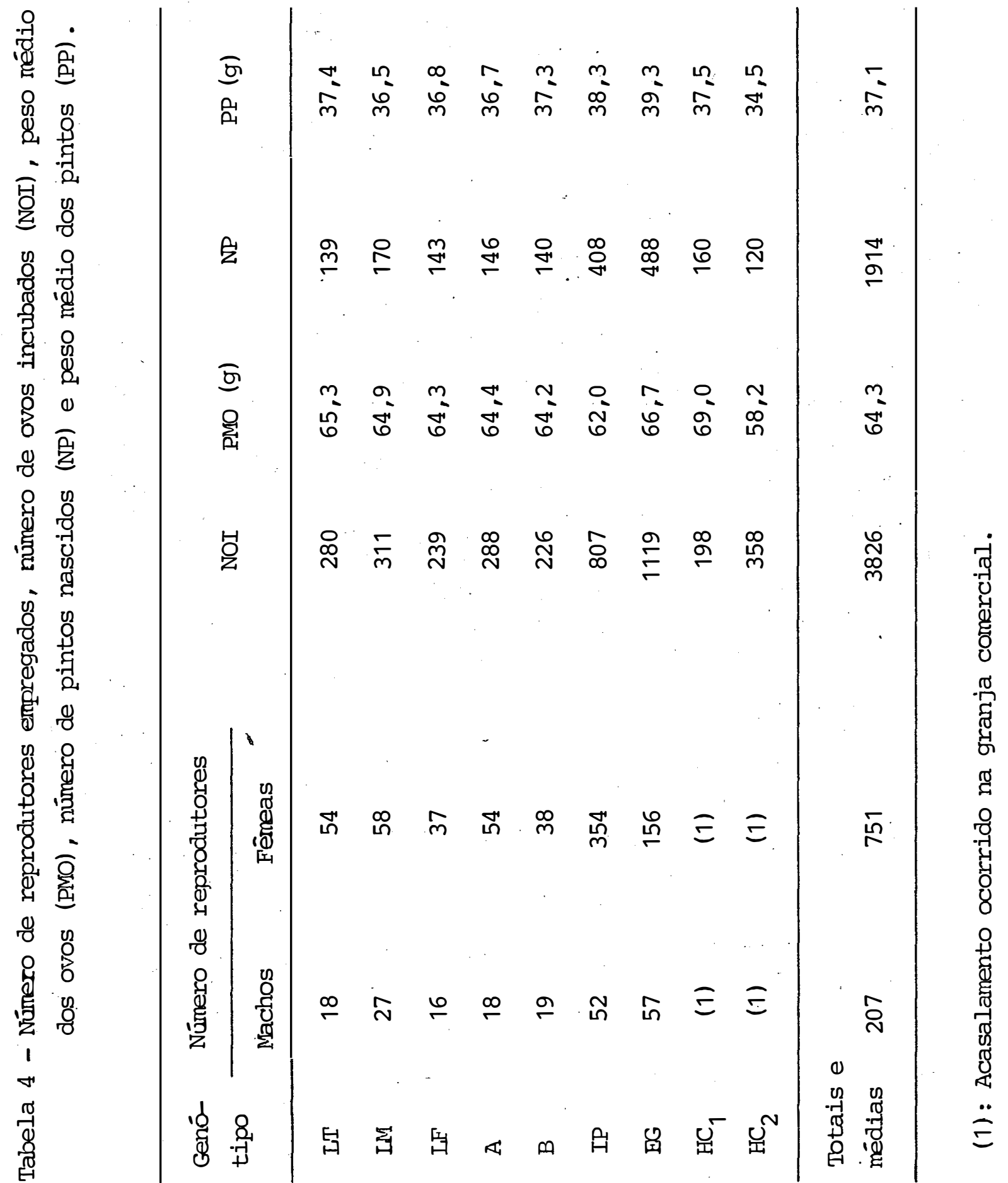


terminados dedos, isto para posterior identificàção de sua origem. Em seguida, os pintos foram vacinados contra a doença de Marek e Epitelioma Contagioso (Bouba). No 19, 20 e 30 dia, foi fornecido Tartarato de Tilosina (Tylan), na água, na proporção de 10 gramas para cada 20 litros de água, para prevenção da Doença Crōnica Respiratória (DCR), e no 7o dia as aves foram vacinadas contra a doença de New-Castle (via ocular). Os pintos foram alojados, sem separação de sexo, em 18 boxes de $6 \mathrm{~m}^{2}$, com 60 pintos por box, totalizando 1080 pintos, com uma lotação de 10 aves $/ \mathrm{m}^{2}$. Cada divisão havia sido previamente aquecida através de uma campânula de raios infravermelhos, que permaneceu ligada até o 14 o dia de vida dos pintos.

Nas tabelas 5 e 6 encontram-se, respectivamente, as percentagens dos ingredientes e a composiçaõ bromatoló gica da ração e a composição dos premix vitamínicos e minerais da ração inicial, que foi fornecida até o 35 ̣ dia e da ração final, fornecida do 369 ao 49 9 dia de vida das aves.

Os bebedouros tipo pressão permaneceram até o 139 dia e foram lavados três vezes ao dia, quando era feito o fornecimento de água às aves. A partir do 110 dia, a água pas sou a ser fornecida tambēm em bebedouros do tipo pendular, os quais foram lavados uma vez ao dia, pela manhã.

Os comedouros tipo bandeja foram utilizados até o 189 dia de vida dos pintos e eram abastecidos várias vezes ao dia. Do 189 dia em diante foram colocados dois comedou 
Tabela 5 - Composição porcentual da ração.

\begin{tabular}{|c|c|c|}
\hline Ingredientes & $\begin{array}{l}\text { Ração Inicial (\%) } \\
0-35 \text { dias }\end{array}$ & $\begin{array}{l}\text { Ração Final (\%) } \\
36 \text { - } 49 \text { dias }\end{array}$ \\
\hline Milho Moído & 64,00 & 67,5 \\
\hline Farelo de soja & 29,50 & 24,3 \\
\hline Farinha de came & 4,00 & 4,00 \\
\hline Farinha de Peixe & 1,00 & 1,0 \\
\hline Cálcareo de Ostra & 0,30 & - \\
\hline Fosfato Bicálcico & 0,50 & 0,25 \\
\hline Sal comum & 0,25 & 0,25 \\
\hline Calmim & 0,25 & 0,25 \\
\hline Premix I & 0,20 & - \\
\hline Prenix II & - & 0,20 \\
\hline Metionina & 0,12 & 0,10 \\
\hline Coban & 0,10 & 0,20 \\
\hline Stafac & 0,002 & 0,001 \\
\hline Proteína Bruta, \% & 22,5 a 23,0 & $18,5-19,0$ \\
\hline $\begin{array}{l}\text { Energia Metabolizável, } \\
\qquad \mathrm{kcal} / \mathrm{kg}\end{array}$ & 2.920 & 3.100 \\
\hline Metionina Cistina, \% & 0,87 & 0,74 \\
\hline Lisina, \% & 1,20 & 0,96 \\
\hline Cálcio, ะ & 1,00 & 1,10 \\
\hline Fösforo disponível, \% & 0,40 & 0,5 \\
\hline
\end{tabular}


Tabela 6 - Composição do prenix, níveis por tonelada de ração acabada.

\begin{tabular}{|c|c|c|}
\hline Vitaminas & Prenix I & Prenix II \\
\hline A & 15.000.000 U.I. & 10.000.000 U.I. \\
\hline $\mathrm{D}_{3}$ & 3.000 .000 U.I. & 2.200 .000 U.I. \\
\hline $\mathrm{E}$ & 30.000 U.I. & 15.000 U.I. \\
\hline & $2.500 \mathrm{mg}$ & $1.000 \mathrm{mg}$ \\
\hline Ácido Fólico & $1.500 \mathrm{mg}$ & $500 \mathrm{mg}$ \\
\hline Ácido Nicotínico & $50.000 \mathrm{mg}$ & $30.000 \mathrm{mg}$ \\
\hline Ácido Pantotênico & $20.000 \mathrm{mg}$ & $10.000 \mathrm{mg}$ \\
\hline $\mathrm{B}_{1}$ & $3.000 \mathrm{mg}$ & $2.000 \mathrm{mg}$ \\
\hline $\mathrm{B}_{2}$ & $10.000 \mathrm{mg}$ & $4.400 \mathrm{mg}$ \\
\hline $\mathrm{B}_{6}$ & $5.000 \mathrm{mg}$ & $2.200 \mathrm{mg}$ \\
\hline $\mathrm{B}_{12}$ & $10 \mathrm{mg}$ & $15 \mathrm{mg}$ \\
\hline Colina & $300.000 \mathrm{mg}$ & $30.000 \mathrm{mg}$ \\
\hline Biotina & $10 \mathrm{mg}$ & - \\
\hline Minerais & Premix I & Premix II \\
\hline Iodo & $220 \mathrm{mg}$ & $220 \mathrm{mg}$ \\
\hline Selênio & $1.000 \mathrm{mg}$ & $1.000 \mathrm{mg}$ \\
\hline Manganês & $60.000 \mathrm{mg}$ & $60.000 \mathrm{mg}$ \\
\hline Cobre & $5.000 \mathrm{mg}$ & $5.000 \mathrm{mg}$ \\
\hline Zinco & $54.000 \mathrm{mg}$ & $54.000 \mathrm{mg}$ \\
\hline Sódio & $12.000 \mathrm{mg}$ & $12.000 \mathrm{mg}$ \\
\hline Potássio & $12.000 \mathrm{mg}$ & $12.000 \mathrm{mg}$ \\
\hline Cálcio & $360.000 \mathrm{mg}$ & $360.000 \mathrm{mg}$ \\
\hline Fösforo & $2.400 \mathrm{mg}$ & $2.400 \mathrm{mg}$ \\
\hline Magnēsio & $5.200 \mathrm{mg}$ & $5.200 \mathrm{mg}$ \\
\hline Anti-axidante & $125.000 \mathrm{mg}$ & $125.000 \mathrm{mg}$ \\
\hline
\end{tabular}


ros do tipo pendular em cada um dos boxes, com quantidade suficiente, de modo a fornecer ração a vontade às aves.

As aves receberam iluminação contínua 24 horas

por dia, durante todo o período de criação. Durante o dia, a iluminação era natural e à noite era dada por lâmpadas incandescentes que permaneciam ligadas do pōr ao nascer do sol.

Semanalmente, até a 4 ạ semana, as aves eram pe sadas coletivamente, ou seja, por parcela, bem como as sobras de ração existentes nos comedouros. A partir da 5ạ semana deu-se início a pesagem individual das aves, com separação de se xo.

Na 5ạ semana de idade, foi feito um teste de soroaglutinação rápida em placás, para detectar uma possível contaminação do lote por Micoplasma (M. gallisepticum e M. si noviae) e Salmonella pullorum, em 3 aves por parcela.

A avaliação da percentagem de gordura abdominal aderida à carcaça, foi feita mediante o abate manual de 3 machos e 3 fêmeas por parcela, em uma das repetições de cada tra tamento, na 7ạ semana de idade.

\subsection{CARACTERÍSTICAS AVALIADAS-}

\subsubsection{CONSUMO : DE RACÃO, PESO CORPORAL, CONVERSÃO ALIMENTAR E VIABILIDADE}

o controle do consumo semanal de ração foi feí 


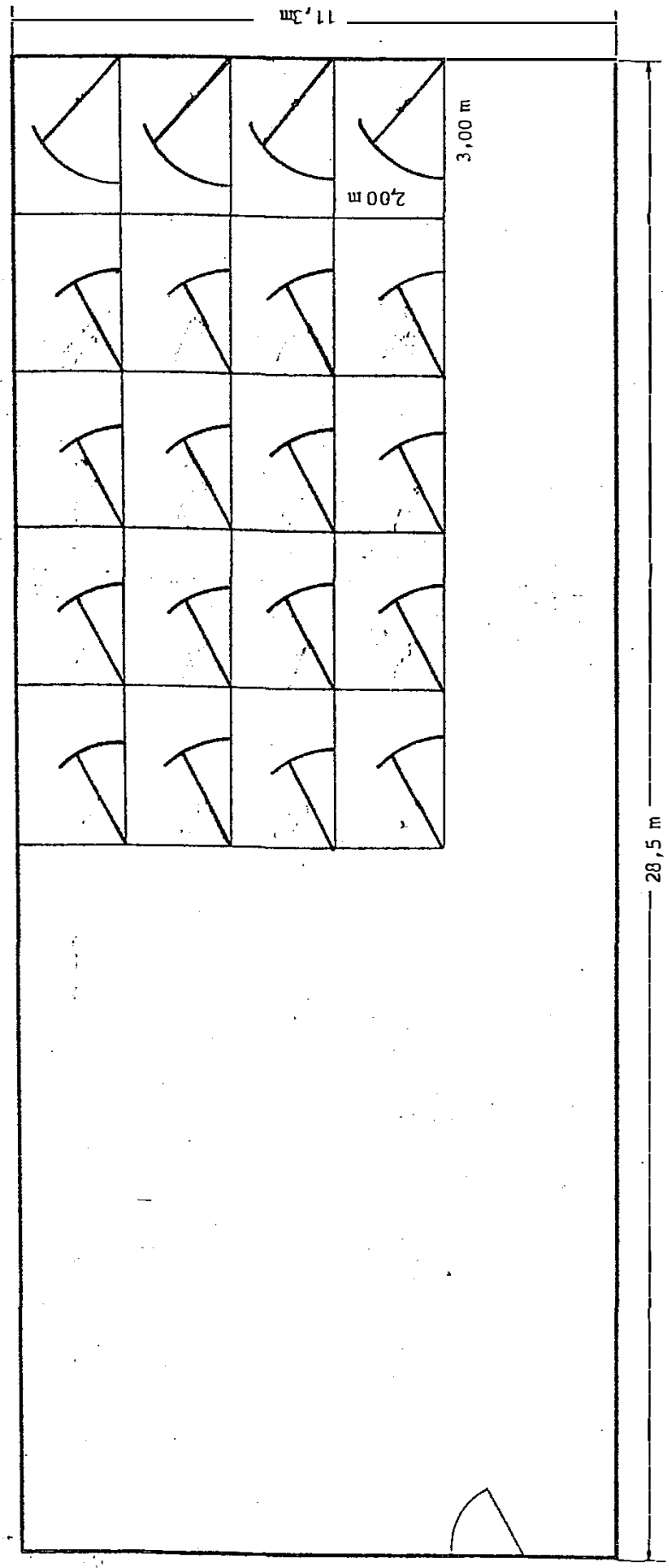

ت્ન 
to por ocasião das pesagens das aves, quando as sobras de ração dos comedouros foram pesadas. Obtieve-se o consumo : médio, dividindo-se o consumo semanal da parcela pelo número de aves existentes na semana.

Até a 4 ạ semana as aves foram pesadas coletiva mente. Dividindo-se o peso da parcela pelo número de avies, foi obtido o peso médio semanal para cada parcela. Na 5ạ, 6ạ e 7ạ semana, as aves foram pesadas individualmente, com separação de sexo. Tanto para consumo como para peso corporal, foi feito um acompanhamento dos valores acumulados.

A conversão alimentar média obtida para cada tratamento foi calculada semanalmente, dividindo-se o consumo médio do tratamento pela média do ganho de peso correspondente naquela semana.

O registro da mortalidade foi feito no dia do evento. A mortalidade semanal foi calculada através do quocien te do número de aves no final de cada semana pelo número de a ves na mesma semana.

\subsubsection{RENDIMENTO DA CARCAÇA E GORDURA ABDOMINAL}

Na 7ạ semana de idade, foram retiradas 3 fêmeas e 3 machos de uma das repetições dos genótipos- $H_{1}$, IP, EG e LT, num total de 24 aves. Retirou-se as aves segundo um critério de pesos, isto é, a mais pesada, intermediária è a mais leve. As aves foram abatidas manualmente, através de destron- 
camento do pescoço e, através do escaldamento as aves foram depenadas. Após a depena e evisceração e com a carcaça ainda quente, foi efetuada a separação da gordura abdominal, visceras e carcaça, que foram pesadas para posterior avaliação.Foi considerada gordura abdominal, a gordura aderida a moela, coração e região da cloaca. Os pesos obtidos foram transformados em porcentagem em relação ao peso vivo e peso da carcaça evis cerada.

\subsection{Delineamento EXPER IMENTAL}

Foi utilizado um delineamento inteiramente casualizado, com nove tratamentos (genótiposos) e duas rep̀etições. sem separação de sexo, perfazendo 18 unidades .experimentais, contendo 60 aves por unidade, totalizando 1080 aves. Na. quinta e sétima semana de idade, as aves foram pesadas individual mente, procedendo-se a separação dos sexos. A análise de variân cia para peso corporal em ambas as idades, conforme GOMES(1976), foi o seguinte:

\begin{tabular}{lc}
\hline Fonte de variação & GL \\
\hline Genótipo (G) & 8 \\
Sexo (S) & 1 \\
G x S & 8 \\
Residuo & 18 \\
\hline TOTAL & 35 \\
\hline
\end{tabular}


No quie.concerne a conversão alimentar, foram e fetuadas duas anālises de variāncia (GOMES, 1976), uma em cada fase do experimento (0 a 35 e 36 a 49 dias). O esquema de análise é apresentado a seguir.

\begin{tabular}{ll}
\hline Fonte de Variação & GL \\
\hline Genótipo (G) & 8 \\
Resíduo & 9 \\
\hline TOTAL & 17 \\
\hline
\end{tabular}

Para as avaliações das características de carcaça foram utilizadas 3 aves de cada população (HC ${ }_{1}$, IP, EG e LT), segundo um critério de peso, totalizando 24 aves. A análise de variāncia, para gordura abdominal e rendimento de car caça, segundo Gomes (1976) é apresentado no quadro abaixo.

\begin{tabular}{lc}
\hline Fonte de variação & GL \\
\cline { 2 - 2 } Genótipo (G) & 3 \\
Sexo (S) & 1 \\
S X G & 3 \\
Resíduo & 16 \\
\hline Total & 23 \\
\hline
\end{tabular}


A análise de comparação de médias ffoi feito na maioria dos casos pelo teste de Tukey, sendo que a comparação dos grupos de genótipos foi através do teste "t" de student. O estudo das relações entre as variáveis consi deradas foi realizado através da determinação das equações de regressão e dos coeficientes de correlação simples. Para a oḅ tenção dos coeficientes de regressão e correlação foram usadọ os pesos individuais das aves vivas, sem penas, da carcaça e.viscerada, das visceras e da gordura abdominal. Os cálculos fo ram feitos de acordo com as técnicas usuais descritas por SNE DECOR (1968) 


\section{RESULTADOS E DISCUSSẤO}

\subsection{CONSUMO DE RACÃO, GANHO DE PESO E PESO CORPORAL}

Os resultados de consumo de ração, ganho de pe so, peso corporal e ordem de mérito relativo a peso corporal, obtidos semanalmente, encontram-se respectivamente, nas Tabelas 7, 9, 10 e 15. Os resultados das médias de peso vivo, com separação de sexo, obtidos para a 5ạ e 7ạ semana de idade são apresentados, respectivamente, nas Tabelas 11 e 13 A análise de variāncia para os dados acima encontram-se na Tabela 16. Nas figuras $3,4,5$ e 6 são apresentados, respectivamente; os desempenhos semanais para o consumo de ração, ganho de peso, peso corporal e a curva de crescimento obtida para os maiores e menores médias de peso corporal. 


\subsection{1, FASE INICIAL (0-35 DIAS)}

Na Figura 3 e Tabela 8 são apresentados, respectivamente a curva de consumo semanal de ração e a análise de variância semanal para esta característica. Embora não se tenha observado diferenças significativas entre os genótipos na 2ạ 3ạ e 4 ạ semana, verifica-se que a partir da 2ạ semana, as diferenças entre os genótipos começam a ficar evidentes, tornando-se significativas na 5a e 6 a semana. sendo que os ge nótipos EG e $\mathrm{HC}_{1}$, apresentaram um maior consumo de ração durante todo o período experimantal (Tabela 21).

A curva de ganho de peso semanal, pode ser ve rificada na Figura 4. Inicialmente, todos os genótipos apresentam o mesmo ganho, ocorrendo uma diferença de $17,7 \mathrm{~g}$.entre o maior (EG) e o menor (LF) ganho. A partir da 2a semana, as diferenças começam: a se tornar evidentes, passando para 107,65g na 5ạ semana, verificando-se, porém, que nem sempre o mesmo genótipo apresenta o maior ou menor ganho. Figurando entre os de maior ganho temos: EG (1), $\mathrm{HC}_{1}$ (5) e IP (1) e entre os de menor: LT (3), LF(3) e LM (1), como pode ser verificado na Ta bela 15 . 
Embora não se tenha verificado uma queda no con sumo, para os genótipos LM e LT, estes apresentavam uma queda no ganho de peso na 2ạ e 5ạ semana, respectivamente. Acredita va-se, inicialmente, que este fato teria ocorrido em função de uma contaminação do lote por Micoplasma e/ou Salmonela, porém os testes sorológicos ( soroaglutinação rápida) não confirmaram a suspeita. $\mathrm{Na} 2 a ̣$ semana, todos os genótipos foram preju. dicados por algum fatọr, que não foi possível identificar (Fi gura 4). Na 5 ạ semana, somente $I P, \mathrm{HC}_{2}$ e $\mathrm{LF}$ não foram influen ciados, notando-se, assim, a existência de comportamento dife rente entre os genótipos, sendo que IP foi o que mais se destacou neste período (Tabela 1:5).

No que concerne ao peso corporal na 5ạ semana, ficou evidente a diferença entre os genótipos, sendo que, apa rentemente, as populações de sintese mais antigas (LT; IM e LF) não conseguiram manter a competitividade, pelo menos nas primeiras 5 semanas, em relação aos híbridọs comerciais, cøomo re vela a análise de variância (Tabela 16). As populações de sín tese mais recente (A e B), por outro lado, apresentaram-se mais competitivas (Tabela 11). Com relação ao material mais recente (IP e EG) verifica-se resultados altamente satisfatórios, suplantando, inclusive, os híbridos comerciais. 


\subsubsection{FASE FINAL (36-49 DIAS)}

As diferenças verificadas para consumo de ração na fase inicial do experimento, foram ainda mais acentuadas durante a segunda fase, determinando, assim, uma maior dị ferença entre os genótipos (Tabela 7). A variação entre o maior e o menor consumo, respectivamente, para a 6a e 7ạ semanas de idade, foram da ordem de $355,96 \mathrm{~g}$ e $388,48 \mathrm{~g}$, o que determina $\underline{u}$ ma diferença média de $53 \mathrm{~g}$ por cabeça/dia, durante a fase final do experimento.

Com relação ao ganho de peso, verifica-se atra ves da Figura 4, a existēncia de diferenças entre os genótipos. Algumas populações apresentaram problemas durante a fase final de crescimento, sendo que EG apresentou uma queda no ga nho de peso, o que não deveria ter ocorrido normalmente. As po pulações LF e IP que tiveram m. queda de peso durante a $6 \ddot{\text { sa }}$ mana, conseguiram recuperar bastante na fase final. As popula ções B e IP, apresentaram :ganho expressivo, porém as demais populações tiveram: desenvolvimento anormal. A diferença en tre os maiores e menores ganhos, que era de $107,65 \mathrm{~g}$ na 5 a semana, passou para $110,5 \mathrm{~g}$ na fase final, mantendo, assim, as dị ferenças entre os genótipos.

No que concerne ao peso corporal na 7ạ semana, ficou ainda mais evidente a diferença entre genótipos e confirmou as expectativas da primeira fase, quando as populações mais antigas (LT, LM e LF) demonstraram a não competitividade 
em relação aos híbridos comerciais $\left(\mathrm{HC}_{1}\right.$ e $\left.\mathrm{HC}_{2}\right)$, como revela a análise de variância (Tabela 16). É evidente que as intensidá des de seleção empregadas não foram suficientes para manter a competitividade destas populações.

A comparação entre as populações de síntese mais recente (A e B) não revelou diferenças significatịas (Tabela 10). A população A, embora apresente médias bem inferiores aos genótipos IP, EG e $\mathrm{HC}_{2}$, não difere das médias destes genótipos. As populações IP e EG apresentaram-se altamente competitivas, não diferindo dos híbridos comerciais e superando :jos demais materiais envolvidos (Tabela 10 e Figura 5).

A análise de contrastes envolvendo as populações $A$ e $B$; LT, LM e LF; IP e EG; $\ldots \mathrm{HC}_{1}$ e $\mathrm{HC}_{2}$, revelaram que os híbridos comerciais e, IP e EG, são superiores às demais populações, porém, não diferem entre si. As populações A e B apresentaram-se superiores a LT, LM e LF, sendo que LT foi a que apresentou menor desempenho. 
48.

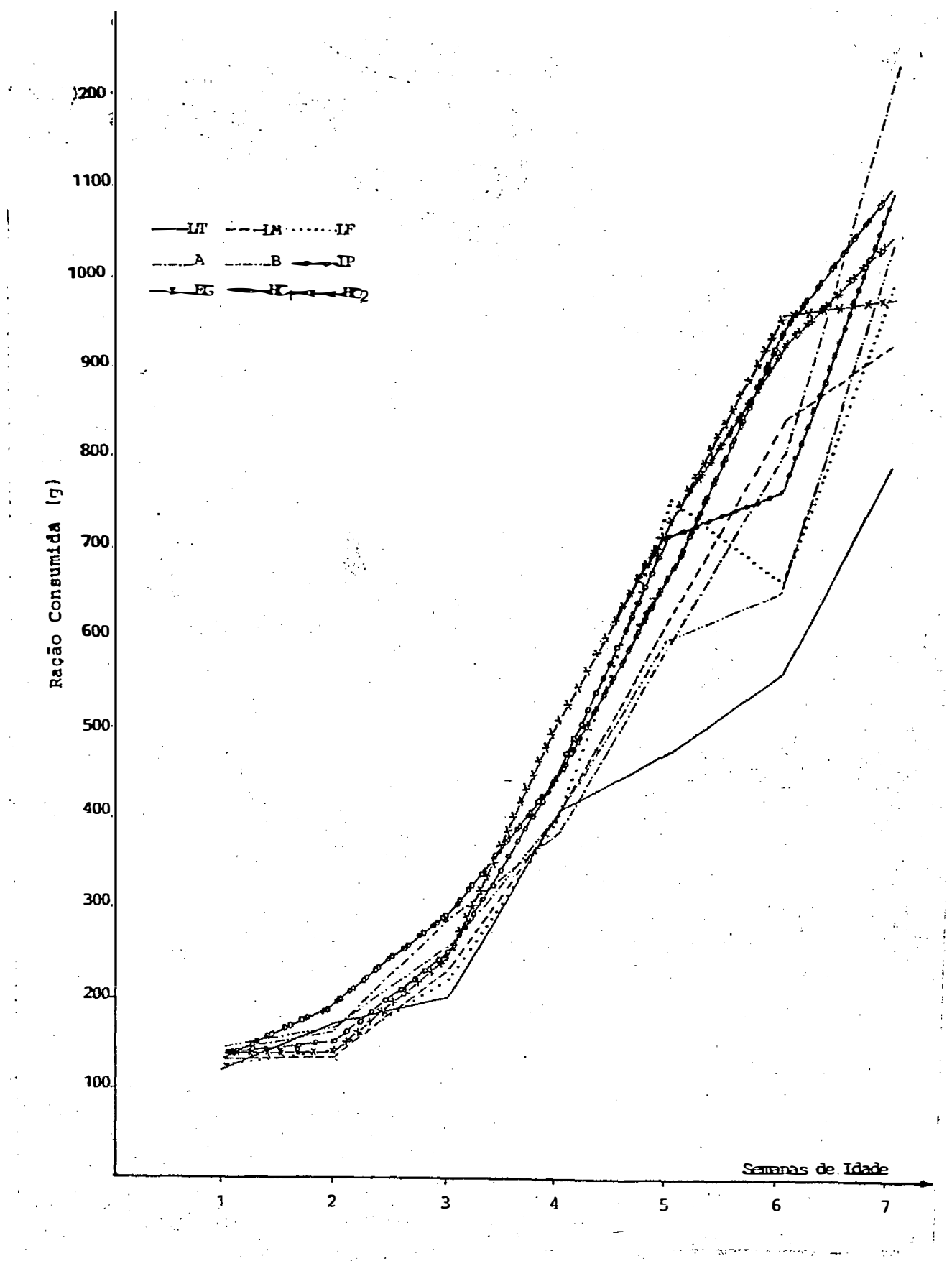

Figura 3 - Consumo semanal de ração, por ave. 


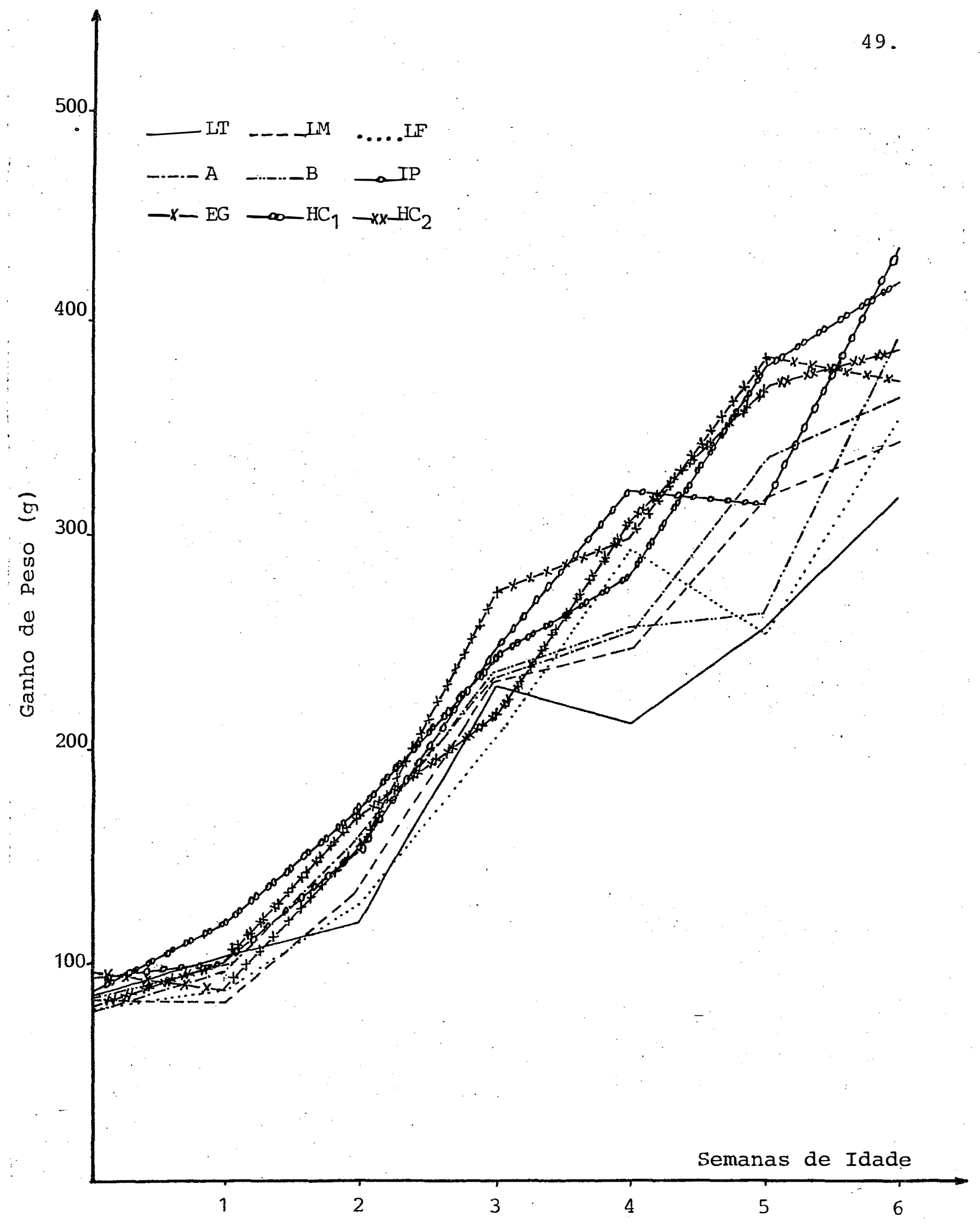

Figura 4 - Ganho de peso semanal, por ave. 


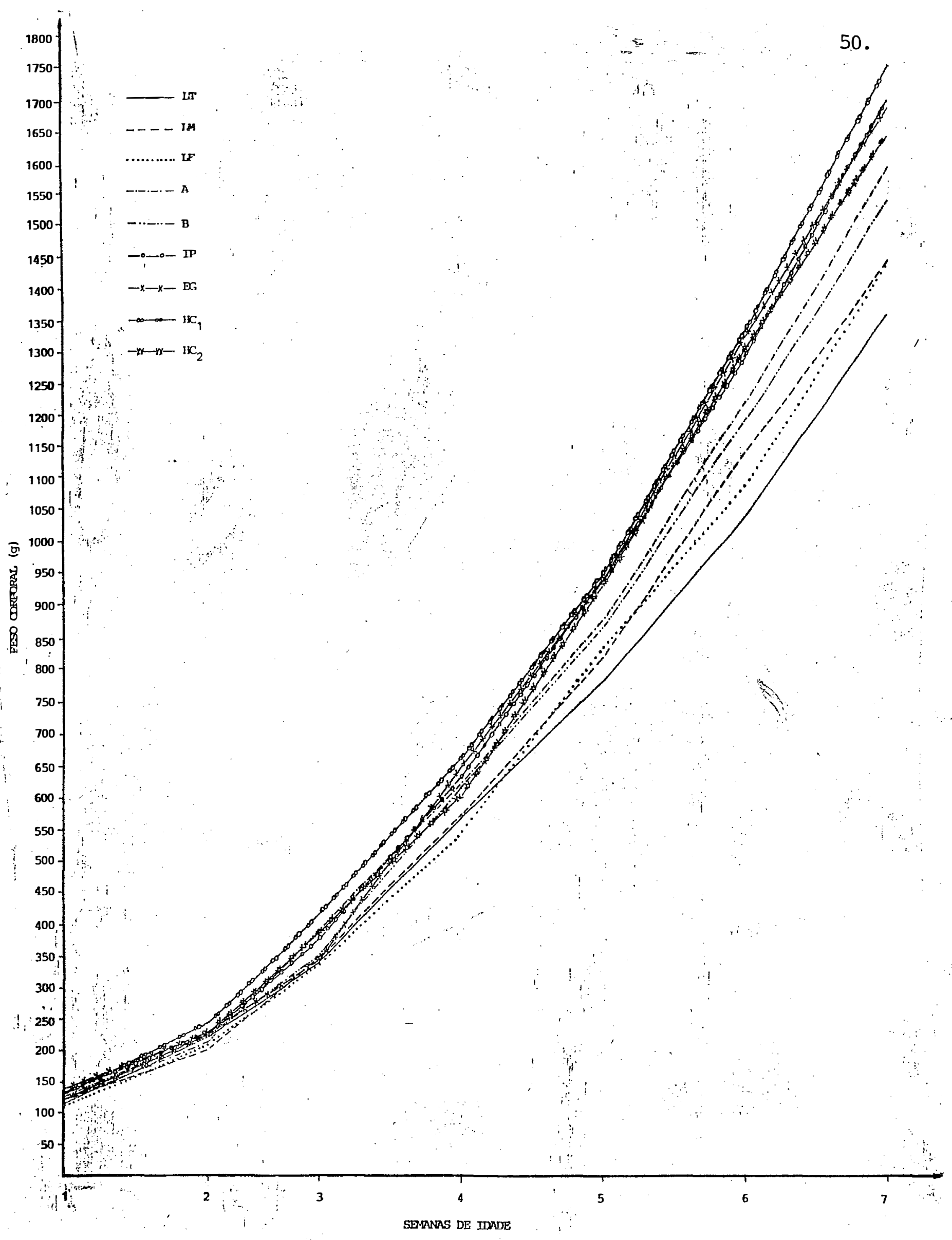

Figura 5 - Peso corporal semanal. 


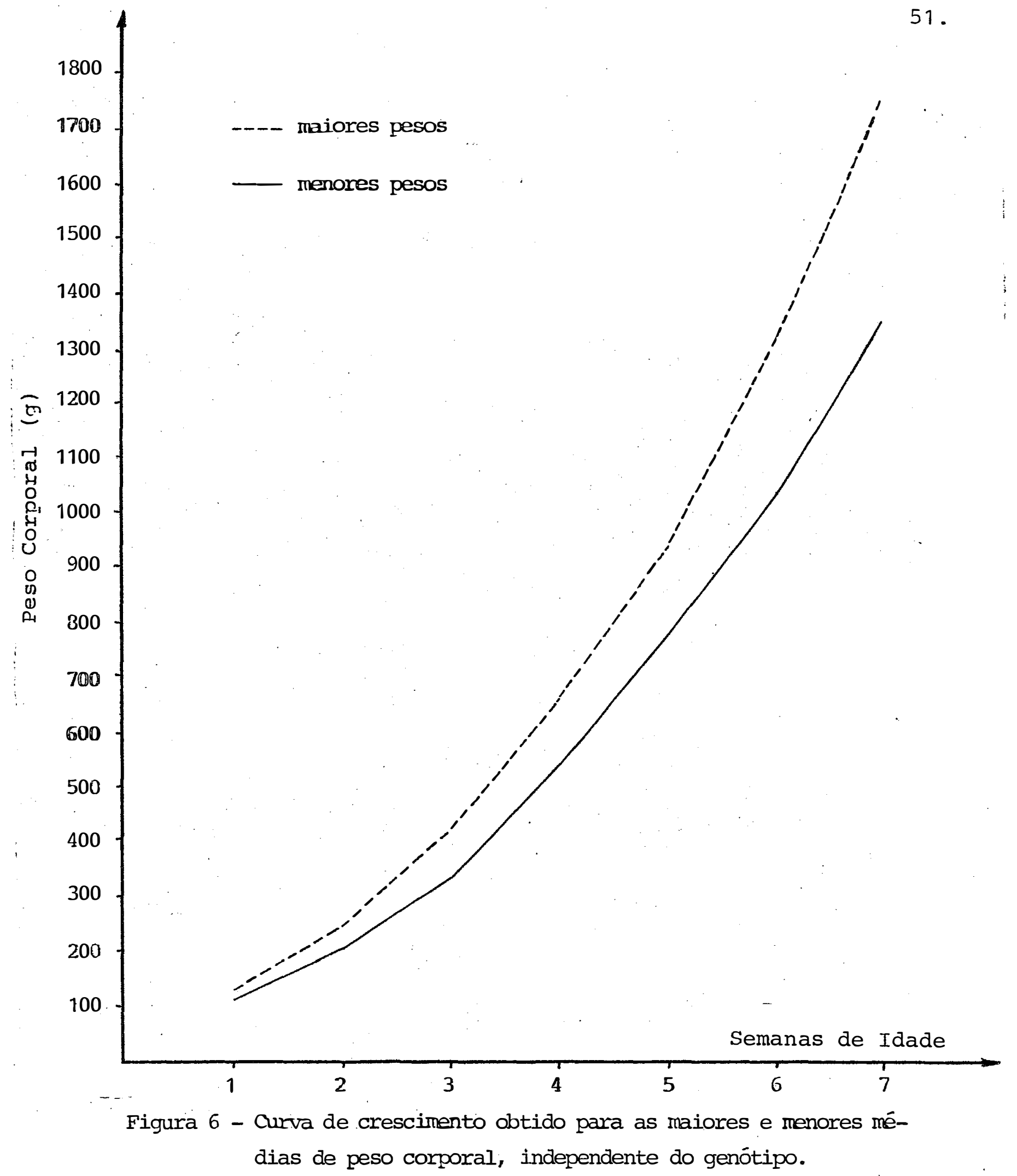


52.

\subsection{CONVERSÃO ALIMENTAR}

Os resultados obtidos para conversão alimentar semanal e a respectiva análise de variāncia são apresentadas nas Tabelas 12: e 19. Na figura 7 verifica--se a curva semanal correspondente a conversão. A conversão alimentar média e a ordem de mérito, obtidas para a 5ạ e 7ạ semana de idade encontram-se, respectivamente, nas Tabelas 18 e 20 .

As diferenças entre os genótipos começarama.fi car evidentes a partir da 3ạ semana de idade (Figura 7 e Tabe la 12). A análise de variância para conversão alimentar média na fase inicial (0 - 35 dias) não revelou diferenças significativas entre as populações, sendo que a diferença $\cdots$ entre a maior (LF) e a menor (LT) conversão, foi de apenas 0,16 unida des. Através da Tabela 12, verifica-se que ocorreu um revezamento entre os genótipos, quanto a melhor desempenho, durante toda a fase inicial.

Para conversão alimentar, na fase final (36 - 49 dias), os genótipos A e LF foram estatisticamente semelhantes; contudo, LF apresentou um menor desempenho em relação aos demais. A diferença entre a maior (A) e a menor (IP) . conversão foi de 0,42 unidades. Embora não se tenha verificado diferenças significativas, os genótipos IP, LT e B apresentaram tendências de melhor desempenho, sendo que as médias para estes genótipos foram, respectivamente, iguias a 2,5;2,59 e 2,59. 


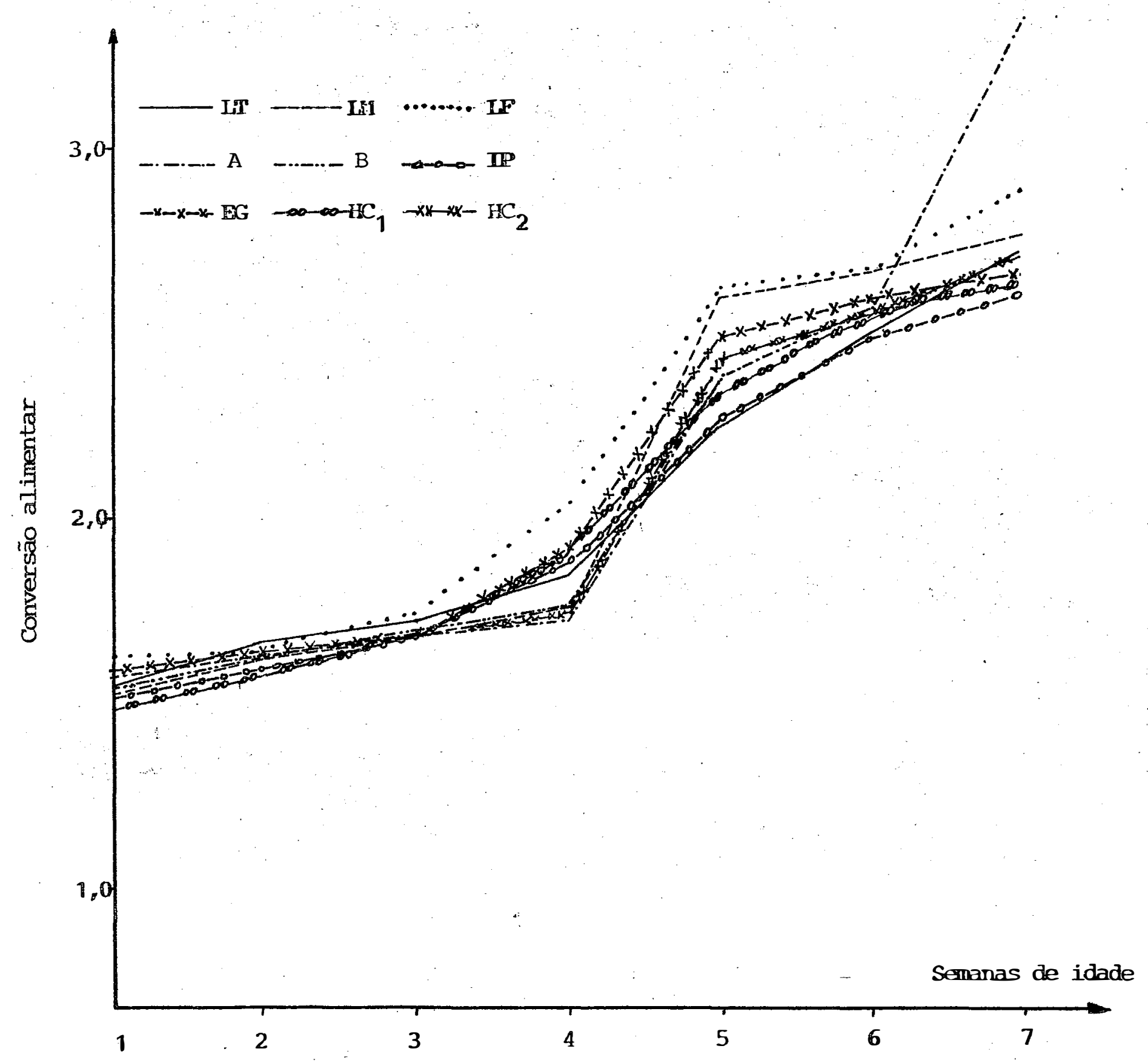

Figura 7 - Conversão alimentar (kg ração consumida/kg ganho peso). 


\subsection{VIABILIDADE}

A viabilidade média obtida na 6ạ e 7ạ semana e a viabilidade total, de 0 a 49 dias, é apresentada, respecti vamente, nas Tabelas 2'1 e 22. Na figura 8 verifica-se a curva de viabilidade semanal, durante toda a fase experimental.

A viabilidade média obtida para o experimento foi de 90,11\%, para 1080 aves, podendo ser considerada anormal. Acreditava-se que alta mortalidade estava ocorrendo em função de uma possível contaminação do lote por Salmonela, Mi coplasma (M. gallisepticum e M. sinoviae) ou Coccdiose, o que não foi confirmada pelos testes sorológicos (soroaglutina ção rápida) e necrópsia.

Os genótipos LM e LF apresentaram tendências de maior viabilidade, sendo que $\mathrm{B}$ e $\mathrm{HC}_{2}$ foram os lotes com menor viabilidade. A diferença entre a maior e a menor viabilí dade foi de $3,26 \%$ (Tabela 22) . 


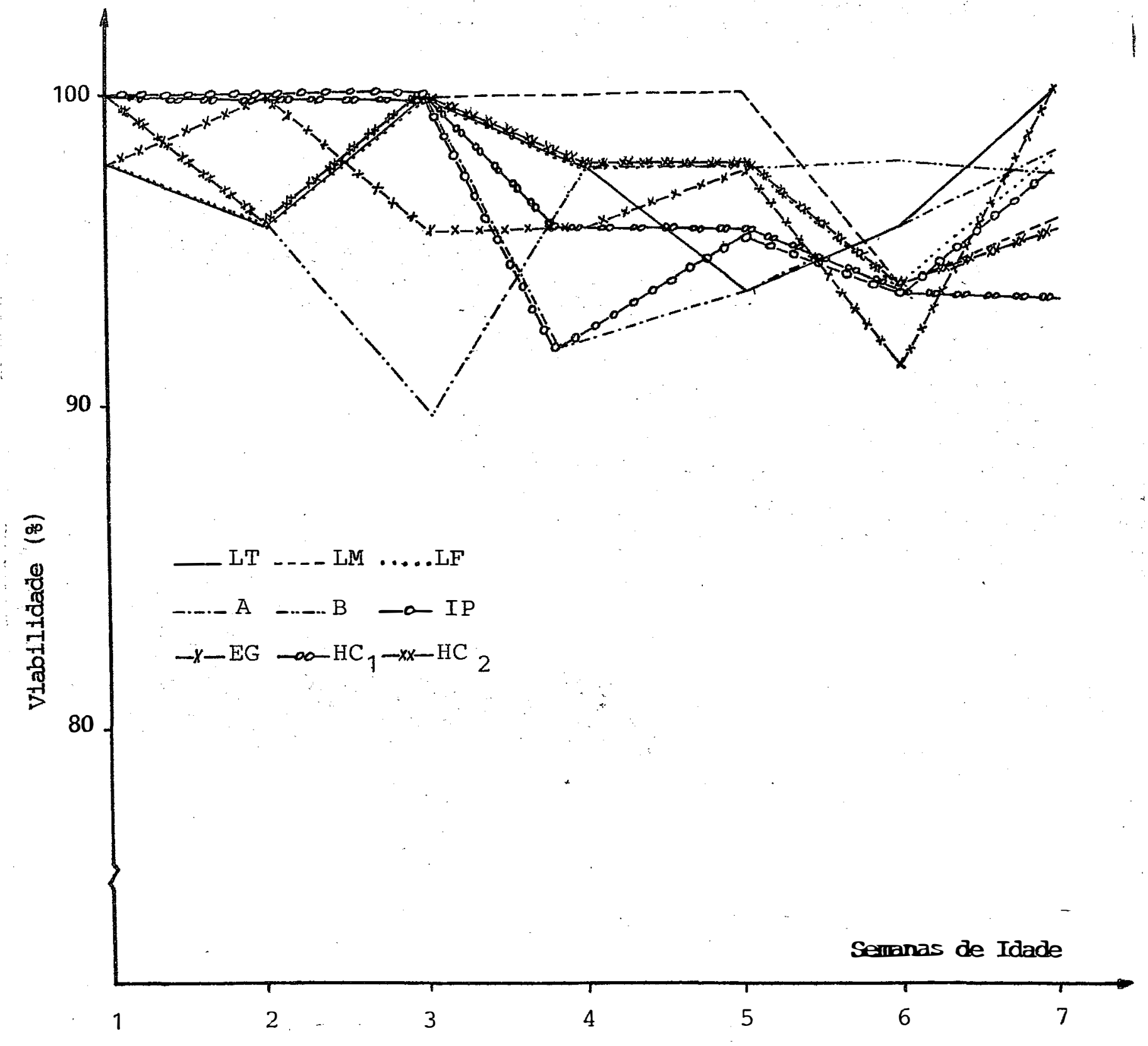

Figura 8 - Viabilidade média semanal. 


\subsection{RENDIMENTO DE CARCACA E GORDURA ABDOMINAL}

Os resultados obtidos individualmente para car caça eviscerada peso sem penas, vísceras comestíveis, gordura abdominal, porcentagem de gordura abdominal em relação ao peso vivo e em relação ao peso eviscerado e rendimento de carr caça são apresentados nas Tabelas 25, 26, 27,28, 29, 30 e 31, respectivamente.

Na Tabela 32 é apresentado um sumário dos resultados obtidos para peso vivo, peso sem penas, carcaça evis cerada, vísceras comestíveis e gordura abdominal. Considerou.. -se como vísceras comestíveis o coração, figado e moela. São também apresentados os pesos médios de machos e fêmeas abatidos para mensuração de carcaça, sendo que os machos eram, em média, 18,9\% mais pesados que as fêmeas.

A análise de variāncia acusou diferenças signị ficativas entre sexo e entre genótipos, quanto ao rendimento de carcaça (Tabela 34). A população IT foi a que apresentou o menor desempenho pós-abate, sendo que as demais populações não diferiram entre si. Em média, os machos apresentaram um rendi mento $4,25 \%$ inferior às fêmeas, resultado este significativo. A diferença de maior magnitude entre os sexos ocorreu na popu lação EG. As aves mais pesadas apresentaram, em média um maior rendimento de carcaça, demonstrando uma correlação alta entre peso vivo e peso carcaça (Tabela 31). Os resultados obtidos pa ra rendimento de carcaça confirmou o obtido por TADLE et alii 
(1955) e MORAN Jr. (1980) que encontraram maiores perdas' decorrentes da sangrià e depena para os machos, porém discordam ods obtidos por ORR (1955), AFIFI e RASHEED (1966) e MORAN Jr. e ORR (1969).

Para a gordura abdominal, a anālise de variância apresentada na Tabela 28, não revelou diferenças entre os genótipos, tanto para porcentagem de gordura abdominal em relação ao peso vivo, como em relação ao peso eviscerado. Quando utilizou-se o peso da gordura aderida à carcaça, foi cons.. tatada uma diferença entre os genótipos, acompanhada de uma in teração significativa entre genótipo e sexo.

Em relação ao sexo, verificou-se diferenças sigg nificativas, para porcentagem de gordura em relação ao peso ví vo e em relação ao peso eviscerado, sendo que as fêmeas apresentam um maior acúmulo de gordura. A diferença entre machos e fêmeas, em relação ao peso vivo e peso eviscerado, foram res pectivamente iguais a 47,9 e $36,0 \%$. Os resultados obtidos para gordura abdominal vem a confirmar os resultados relatados por vários autores, entre eles, GOODWIN (1980) e MENDES et al li (1981), contudo superiores ao descrito por ISLABÃO (1970), que constatou que as fêmeas depositavam, em média, 11,2\% mais gordura que os machos.

Na Tabela 35 são apresentados os coeficientes de correlação e as respectivas equações de regressão, para ca racterísticas de carcaça. O estudo das correlações entre as va 
riáveis consideradas, revelam valores altos e positivos para peso sem penas $(0,997)$ e carcaça eviscerada $(0,970)$, ambas em relação ao peso vivo. Embora se tenha verificada a tendência de maior acúmulo de gordura abdominal por parte das aves de maior peso, naõ foi constatada uma correlação significamte en tre peso vivo e gordura e peso eviscerado e gordura, sendoque os valores dos coeficientes de correlação foram iguais a $-0,01$ e 0,11 , respectivamente. Estes resultados são conflitantes com os obtidos por MAYER et alii (1962) e ANDREWS (1970), que verificaram valores respectivamente iguais a 0,42 e 0,41 . As de mais correlações obtidas foram: 0,585 para peso vivo e visceras; 0,306 para peso de carcaça e vísceras e 0,418 para vísce ras e gorduras. 


\section{CONCLUSÕES}

Os resultados obtidos neste trabalho mostraramidi ferenças estatisticamente significativas entre os genótipos e sexos, possibilitando apresentaras seguintes conclusões :

1. As populações de síntese mais antiga (LT, LM e LF) não conseguiram. manter a competitividade, em relação aos híbridos comerciais, ficàdo evidente gue as intensidades de seleçãoem pregadas não foram suficientes para acompanhar o desenvolvimento das linhagens comerciais;

2. As populações de síntese mais recentes (A e B) apresen taram resultados inferiores aos híbridos comerciais e aos materiais IP e EG.

3. Os genótipos IP e EG apresentaram um desempenho muito promissor, indicando um grande potencial comomatéria-prima pa- 
ra a sintese de novas populações a serem utilizadas no progra ma de melhoramento;

4. A população LT apresentou um baixo rendimento de carcaça, em comparação com os demais materiais utilizados;

5. As fêmeas apresentaram um maior rendimento de carcaça e um maior acúmulo de gordura abdominal;

6. Os genótipos não apresentaram diferenças quanto à porcen tagem de gordura abdominal expressa em relação ao peso vivo e peso eviscerado, contudo, quando a avaliação foi feita em função da quantidade de gordura aderida à carcaça, a população LT apresentou uma maior deposição;

7. A deposição de gordura abdominal não apresentou una cor relação expressiva com o peso vivo e peso da carcaça eviscera da, sendo que os respectivos coeficientes de correlação foram iguais a $-0,01$ e 0,11 .

8. O peso eviscerado e peso sem penas apresentaram uma alta correlação com o peso vivo, sendo os coeficientes de correlaçao iguais a 0,997 e 0,970, respectivamente. 
61.

\section{LITERATURA CITADA}

ABPANALP, H.; V.S. ASMUNDSON e Z.M. LERNER, 1960. Experimental test of a selection index. Poultry Sci., 39: 151-160.

ABRAM, J.L. e T.L. GOODWIN, 1977. A study of broiler carcass yields from five commercial strains. Poultry Sci., 56(2): 1691-1692.

ABREU, R.D.; P.R. SOARES; M.A. SILVA; A.S. GRAÇAS A J.B. FONSECA, 1982a. Rendimento de carcaça, porcentagem de gordura de quatro marcas comerciais de frangos de corte em diferentes niveis protéicos na fase final. In: Anais da XIX Reunião da Soc. Bras. Zootec., Piracicaba, SP, 22-23. 
ABREU, R.D.; P.R. SOARES; M.A. SILVA; A.S. GRAÇAS e J.B. FONSECA, 1982b. Rendimento de carcaça, porcentagem de gordura de quatro marcas comerciais de frangos de corte em diferentes niveis protéicos na fase final. In: Anais da XIX Reunião da Soc. Bras. Zootec., Piracicaba, SP, 24-25.

AFIFI, M.A. e A.A. RASHEED, 1966. Slaugher and carcass studies on 12-week old Fayoumi and Rhode Island Red bird́s. Poultry. Sci., 45: 801-805.

ANDREWS, L.D., 1979. Correlations among production parameters in broilers. Poultry Sci., 58(41): 1031-1040.

ASMUDSON, V.S. E I.M. LERIVER, 1933. Inheritance of rate of growth in domestic fowl. 2. Genetic in growth of Leghorn. Poultry Sci., 12: 250-255.

ARAFA, A.S.; M.A. BOONE; D.M. JANKY, H.R. WILSON; R.D. MILES e R.H. HARMS, 1983. Energy restriction as a means of reducind fat pads in broilers. Poultry Sci., 62: 314-320.

AR'KOV, A.A., 1977. Multiple correlations among external characteres of meat-line chicks. Poultry Abst., 3 (4): 94-95.

BECKER, W.A., 1978. Genotypic and phenotypic relation of abdominal fat in chicks. In: 27th Annual National Breeder's Roudtable, Kansas City, Missouri. 
BECKER, W.A.; J.V. SPENCER; L.W. MIROSH E J.A. VERSTRATE, 1979. Prediction of fat live weight in broiler chickens using backsin fat, abdominal fat, and live body weight. Poultry Sci., 58: 835-842.

BOONE, M.A.; J.A. DAVIDSON e E.P. REINEKE, 1950. Thyroid studies in fast and slow feathering Rhode Island Red chicks. Poultry Sci., 29: 195-200.

BOUWKAMP, E.L.; D.E. BIBEE e C.J. WABECK, 1973. Strain influence on broiler parts yields. Poultry Sci, 52: 1517$-1523$.

BRENES, A.; K. TAKASHASHI e L.S. JENSEN, 1983. Effect of early nutrition on abdominal fat in broiler. Poultry Sci., 62: 1389.

BRIQUET Jr., R., 1967. Melhoramento Genético Animal. Ed. Universidade de São Paulo, 269p.

BRUNSON, C.C.; G.F. GODFREY e B.L. GOODWIN, 1956. Types of gene action in the inheritance of ten-week body weight and breast angle in broilers. Poultry Sci., 35: 524-532. 
CAMPOS, E.J. e M.A.G. CHQUILOFF, 1966. Estudo sobre o rendimento de uma ave comercial especializada para produção de carne. Arg. da Esc. de Med. Vet: UFMG, 18: 113-121.

CAMPOS, E.J., 1975. Criação de frangos de corte com ou sem separação de sexo. In: Tópicos Avícolas. Belo Horizonte, MG, $352-368$

CAVALHEIRO, A.; S.C. OLIVEIRA e D.S. TRINDADE, 1982. Teste de desempenho e resposta econômica de algumas marcas comerciais de frangos de corte criadas no Rio Grande do Sul. In: Anais da XIX Reunião da Soc. Bras. Zootec., Piracicaba, SP, 45.

CAVE, J.A.; P.B. SIEGEL e W.L. BEANE, 1978. Genetic-nutritional relationships in growth and carcass characteristic of broiler chicks. Poultry Sci., 57: 1482-1487-

CHQUILOFF, M.A.G. e E.J. CAMPOS, 1967. Estudo das relações do peso da carcaça com os pesos dos principais cortes obtidos no frango tipo carne. In: Arq. da Esc. Vet. da UFMG, 19: $177-188$

COOKE, R.E.; T.B. CLARK; R.S. DUNBAR E C.J. CUNNINGHAN, 1956. The correlations between broiler qualities, the heritabilities of qualities and the the of selection indexes in chickens. Poultry Sci., 35: 1137-1138. 
COSTA, M.N: e R.W.S. CUSTÓDIO, 1979. Taxa reprodutiva de galinhas para corte em acasalamento efetuados para a avaliação de populações, matrizes e híbridos (ciclo 1979/80). Rel. Cient. Inst. de Genética. Piracicaba, 13.

CUSTÓDIO, R.W.S. e I.U. PACKER, 1976. Desempenho de frangos de corte (Taxa de crescimento de machos: Piracicaba, 1976). Rel.'Cient. Inst. de Genética. Piracicaba, 10:'92-96.

CUSTÓDIO, R.W.S. e S. ZABOROVSKY, 1977. Desempenho de híbridos das populações LT, LM e LF, relativo a taxa de crescimento (Piracicaba, 1976). Rel. Cient. Inst. de Genética. Piracicaba ; $11: 48-51$.

CUSTóDIO, R.W.S., 1978. Alterações genéticas e ambientais observadas em populações de galinhas para corte, submetidas a seleção para taxa de crescimento. Rel. Cient. Inst. de Genética. Piracicaba, 12: 64-73.

DANSKY, L.M. e F.W. HILL, 1952. The influence of dietary energy distribution of fat in various tissues of the growing chickens. Poultry Sci., 31: 912-924.

DEATON, J.W:; L.F. KUBEMiA, T.C. CHEN e F.N. REECE, 1974. Factors influencing abdominal fat in broilers. 2. Cage versus floor rearing. Poultry Sci., 53: 574-576. 
DEV, D.S.; R.G. JAAP e W.R. HARVEY, 1969. Results of selection for eight-week body weitht in three broilers populations of chicks. Poultry Sci., 48: 1336-1348.

EDWARDS Jr., H.M., 1971. Effect of nutrition on the body composition of broilers. In: Georgia Nutr. Conf. for the Feed Industry. Univ. of Georgia, Atlanta.

FALCONER, D.S., 1954. Asymetrical responses in selection experiments. In: Inst. Sci. Biol., 5: 16-41.

FARR, A.J.; J.A. HEBERT e.W.A. JOHNSON, 1977. Studies of the effects of dietary energy levels and commercial broiler strains on live bird, dry carcass, and abdominal fat weights. Poultry Sci., 56: 1713-1724.

FRENCH, J.H.L., 1971. Importance of major gene effects on quantitative traits in fowl. Iowa Sta University, 98p. [Ph.D. Dis.] .

FRIARS, G.W.; C.Y. LIN; D.L. PATTERSON E L.N. IRWIN, 1983. Genetic and Phenotypic parameters of fat deposition and associated traits in broilers. Poultry Sci., 62: 1425 .

FESTING, M.F. e.A.W. NORDSKOG, 1967. Response to selection for body weight and egg weight in chickens. Genetics, 55: $219-231$. 
GODFREY, G.F. e B.I. GOODMAN, 1956. Genetic variation and covariation in broiler weight and breast width. Poultry Sci:, 35: 47-50.

GHION, E., 1979. Desempenho de hỉbridos de aves - Gallus gallus (Linnaeus, 1758) de uma linhagem especializada para corte "vesus" machos irmãos da linha matriz materna. Rendimento de carcaça. Fac. Med., Vet. e Zool. da USP, São Pau1o, 137p. [Tese de I:ivre-Docência].

GOMES, F.P.,1976. Curso de Estatistica Experimental. 5ed. Editora Nobel, São Paulo. 430p.

GOODMAN, B.L. e G.F. GODFREY, 1956. Heritability of body. weight in the domestic fowl. Poultry Sci., 35: 50-55.

GOODMAN, B.L.; J.F. GRIMES e R.G. JAAP, 1957. Repeatability estimates of genetic variance within two closed-flock strains. Poultry Sci., 36: 1121 .

GOODMAN, B.L. e R.G. JAAP, 1960. Improving accuracy of heritability estimates from diallel and triallel matings in poultry. 1. Eight-week body weight in closed flock strains. Poultry. Sci., 39: 938-944.

GOODWIN, T.L., 1980. Excessively fat broilers. Poultry Digest, August, $380-382$. 
M, C.M. e J.A. PEARSON, 3s, Meat yielas still have scope for improvement. Word's Poultro Industry, 86 (7): 21-24.

HATHAWAY, H.E.; G.B. CHAMPAGNE; A.В. WATTS e C.W. UPP, 1953. Meat yield of broilers of differents breeds, strains and crosses. Poultry Sci., 32: 968-977.

HEBERT, B.A. e C.C. BRUNSON, 1957. The effects of diethy:stilbestrol, testosterone, thiouracil e thyroproteins on the chemical composition of broiler carcasses. Poultry Sci., 36: $898-904$.

HILL, W.G. e L.M. DA.NSY, 1954. Studies on the energy requeriments of chickens. Poutry Sci., 33(1): 112-119.

HILL, J.F. e A.W. NORDSKOG, 1958. Predicting combining ability of performance in the crossbred fowl. Poultry sci., 37: 1159-1169.

HILL, W.G., 1971. Design and efficiency of selecition experiments for estimating genetic parameters. Biometrics, 27: $293-311$.

HILL, W.G., 1972a. Estimation of realized heritabilities from selection. Biometrics, 28: 747-765. 
HILL, W.G., 1972b. Estimation of genetic change. 2. Experimental evaluation of control populations. Anim. Breed. Abstract, $40: 193-213$

HOOD, R.L., 1981. Effect of selection on lipogenesis and adipose tissue cellularity in the chickens. Poultry Sci., 59: $1621-1631$.

IRWIN, M.R.; E.P. REINEKE e C.IT. TURNER, 1943. Effect of feeding thyroactive iodocasein on growth, feathering, and weights of young chicks. Poultry Sci., 22: 374-380.

ISLABÃO, N., 1970. Níveis energéticos e protéicos em raçao em ração inicial para fungo de corte e seus efeitos no crescimento e composição da carcaça. Univ. Fed. de Viçosa, MG, 78p. [Tese de Mestrado]

JAAP, R.G. e L. MORRIS, 1937. Genetical differences in eight-weeks and feathering. Poultry Sci., 16: 44-48.

JAAP, R.G.; M.M. RENARD e R.D. BUCKING-HAM, 1950. Dressed and eviscerated meat yields from chickens at twelve-weeks of age. Poultry Sci., 29: 874-880.

JAAP, R.G.; J.H. SMITH e B.L. GOODMAN, 1962. A genetic analysis of growth and egg production in meat type chickens. Poultry Sci., 41: 1439-1446. 
JAAP, R.G., 1963. Selection for rapid growth rate in chickens. Poultry Sci., 42: 1393-1397.

KHAN, J.; W.F. KRUEGER e W.H. WUISEMBERRY, 1958. Non-additive genes effects of size broiler traits as studied from a series of diallel matings. Poultry Sci., 38: 972-981.

KHAN, A.G., 1972. Selection response and the performance of crossbred progeny from normal and dwarf broiler breeder damis. Iowa, State Univ., 92p. [Ph.D. Diss.].

KINNEY, T.B. e R.N. SHOFFNER, 1965. Heritability estimate and genetic correlation among several traits in meat-type poultry populations. Poultry Sci., 44: 1020-1032.

KINNEY, T.B. e R.N. SHOFFENER, 1967. Phenotypic and genetic response to selection in a meat type poultry population. Poultry Sci., 46: 900-910.

KINNEY Jr., T.A., 1969. A summary of reported estimates of heritabilities and of genetic and phenotypic correlations for traits of chickens. United States Dept. of Agric., ·A.R.S., Agric. Handbook, no 363. 
KUBEMA, L.F.; J.W.; T.C. CHEN e F.N. REECE; 1974. Factors influencing the quality of abdominal fat in broilers. 1. Rearing temperatures, sex, age or weight and dietary choline chloride and inositol supplementation. Poultry Sci., 53: $211-214$.

LEESON, S. E J.D. SUMMERS, 1980. Production and carcass charcteristic of the broiler chickens. Poultry'Sci., 59: $786-798$

LERNER, I.M.; V.S. ASMUNDSON e D.M. CRUDEN, 1947. The improvement of NewHampshire fryers. Poultry Sci., 26: 515-524.

LIN, C.Y.; G.'ं. FRIARS e E.F. MORAN, 1980. Genetic and environmental aspects of obesity in broilers. World's Poultry Sci. J., 36: 103-111.

LIN, C.Y., 1981. Relationship between increased body weight and fat deposition in broilers. World's Poultry Sci. J.. $37(2): 107-110$

LITTLEFIELD, L.H., 1972. Strain difference in quantity of abdominal fat in broilers. Poultry Sci., 51: 1829:

MALONE, G.W.; G.W. CHALOUPKA; J.W. MERKELEY e L.H. LITTLEFIELD, 1979. Evaluation of five commercial broiler crosses. 1. Growth performance. Poultry Sci., 58: 509-515. 
MARTIN, G.A.; E.W. GLAZENER e W.L. BLOW, 1953. Efficiency of selection for broiler growth at various age. Poultry Sci., 32: $716-720$.

MARKS, H.L. e P.B. SIEGEL, 1971. Evaluation of Athens-Canadian Randombreed populations: 1. Time trend at two locations. Poultry Sci., 50: 1405-1411.

MATHER, K., 1955. Response to selection. Synthesis Cold Spring Harbor on Quant. Biol., 20: 158-165.

IMAYER, S.E.; W.M. COLLINS e W.C. SHOUGLUND, 1962. Heritability of body weight at three ages: in crossbread broiler chickens resulting from two system of breeding. Poultry Sci., 41: $1374-1381$.

MCCARTNEY, M.G., 1961. Heritabilities and correlation for body weight and conformation in a Randombreed population. Poultry Sci., 40: $1694-1700$.

MENDES; A.A.; A.A. RAMOS; R. POLASTRE; O.E.N. MENDES E E.A. GARCIA, 1981. Efeito da linhagem no desempenho de frangos de - corte. In: Anais do VII Congresso Brasileiro de Avicultura, Recife, PE, 116-124. 
MERKLEY, J.W.; B.W. WEILAND; G.W. MALONEY E G.W. CHALOUPKA, . 1980. Rendimento de fracciones de cinco cruzas. In: Indūstria Avícola, fevereiro, p.40.

MIEILLI, H.L.F.; N.J.L. DIONELLO e R.A. CARDELLINO, 1981. Herdabilidades e correlações genéticas entre pesos na $8 a ̣$ e 16a semanas, e ganho de peso em White Leghorn. In: Anais da XVIII Reunião da Soc. Bras. Zootec., Goiānia, Go, 243.

MORAN Jr., E.T. e H.L. ORP, 1969. A characterization of the chicken broiler as a function of sex and age: Live performance, processing grade and cooking yields. Food Technology, $23: 1077-1084$

MORAN Jr., E.T., 1980. Impact of reducing finishing feed energy-protein level on performance, carcass, yield and grade of broiler chickens. Poultry Sci., 59: 1304-1310.

MORLEY, F.W.H.W., 1958. Utilization of heterosis in poultry. Aust. J. Agr. Res., 9 : 599-608.

NELSON, T.S., 1980. Feeding for changes in body composition of broilers. In: Proc. Florida Nutr. Conf., 159-172.

OLOUFA, M.M., 1955. Effect of thyroprotein on the growth of Egyptian Baby chicks. Poultry Sci., 34: 1292-1294. 
ORR, H.L., 1955. Effect of strain, sex and diet on dressing percentage and on cooked meat yield of ten-week old broiler. Poultry Sci., 34: 1093-1097.

PEZZATO, L.E.; A.A. MENDES; J.L.G: SOUZA; E.A. GARÇÃA e A.S.A. MEIRA, 1981: Rendimento de carcaça de frangos de corte. 1. Efeito da linhagem e sexo. In: Anais do VII Congresso Brasileiro de Avicultura, Recife, PE, 149-156.

PROUDMAN, J.W.; W.J. MELLEN e D.L. ANDERSON, 1970. Utilization of feed in fast and slow growing lines of chickens. Poultry Sci., 49: 961 .

RANGANATHAN, M.; M.P. ARUMUGAN e R. NATARAJAN, 1967. A sțudy on the dressing of Rhode Island Red, White Leghorn and Desi Cockerls. Indian Vet: J.; 44: 956-961.

RICHARD, F.H. e R. ROUVIER, 1967. Étude de la composition anatomique du poulet. 1. Variabilite de la repartition des differentes parties corporelle chez de coquelets "Bresse-Pile". Anm. Zootech., 16: 23 .

RICHARD, F.H. e R. ROUVIER, 1969.'Étude de la composition anatomique du poulet. 2. Variabilite de la repartition des parties corporelle dans une souche de type Cornish. Anm. Genet. Sel. Anim., 1: 151. 
SCHMIDT, G.S. e R.W.S. CUSTÓDIO, 1980. Avaliação de pacotes genéticos nacionais de frangos de corte, obtidos no Instituto de Genética da ESALQ/USP, com relação às suas taxas de crescimento. In: Anais do I Cong. Bras. de Inic. Cient. em Ciênc. Agrár., FCAVJ, Jaboticabal, SP, 149-150.

SCHMIDT, G.S.; R.W.S. CUSTÓDIO; M.A. GIANONNI, 1981. Desempenho de três populações de galinhas melhoradas para corte, seus híbridos e duas linhagens comerciais. Rel. Cient. Inst. de Genética. Piracicaba, 15: 219-229.

SCHUWARTZEBERG, N.; R.L. ADANS e W.J. STADELMAN, 1981. Correlation of fat thickness from to actual weight of broiler fat pad. Poultry Sci., 59: 1659.

SIEGEL, P.B., 1962. Selection for body weight at eight-weeks of age. 1. Selection response and heritabilities. Poultry Sci., 41 : 954-962.

SIEGEL, P.B., 1963. Selection for body weight at eight-weeks of age. 2. Correlated responses of feathering, body weights, and reproductive characteristics. Poultry Sci., 42: 896-905.

SILVA, R.D.M., 1972. Mielaço em pó de cana-de-açúcar na alimentação de frango de corte e seus efeitos no crescimento e qualidades comerciais da carcaça. ESALQ/USP, Piracicaba, 127p. [Tese de Doutorado]. 
SILVA, R.D.M.; M. GRANER; I.U. PACKER; M.D. DORIZZOTTI E M.S.B. OLIVEIRA, 1982. Composição quỉmica de carcaças de frangos de corte alimentados com rações de teores nutritivos e alimentares diferentes. In: XIX Reunião Anual da Soc. Bras. Zootec., Piracicaba, SP, 18-19.

SINGH, S.P. e E.O. ESSARY, 1974. Factors influencing dressing percentage and tissue composition of broilers. 'Poultry Sci., 49 : 725-739.

SNEDECOR, G.W. e W.G. COHRAN, 1968. Statistical methods. Iowa State University Press, Ames, IA.

SMITH, J.H., 1957. Estimation of genetic variance of body weight among progeny of diallel mating in poultry. The Ohio State University. [M.S. Thesis].

TADLE, J.; M.N. LEWIS; A..R. WINTER e R.G. JAAP, 1955. Cooked adible meat in parts of chicken. 1.1 Broiler. J.Amer. Dietet. Ass., 31: 597-600.

TURNER, C.W.; M.R. IRWIN e E.P. REINEKE, 1944. Effect of feeding thyroactive iodocasein to Barred Rock cockerels. Poultry Sci., 23: 242-246. 
WETHLI, E. e J.P.H. WESSELS, 1973. The associations between body fat content and thyroid activity feed intake, mass gain, feed conversion and final body mass in growing chickens. Agroarrimalia, $\underline{5}: 83$.

WHEELER, R.S.; E. HOFFMAN e C.L. GRAHAN, 1948. The value of thyroprotein in starting, growing and laying rations. 1. Growth, feathering and feed consumption of Rhode Island Red broilers. Poultry Sci., 27: 103-111.

WILSON, H.R.; M.A. BOONE; A.S. ARAFA E D.M. JANKY, 1983. Abdominal fat reduction in broilers with thyroactive Iodinated Casein. Poultry Sci., 62: 811-818.

YAO, T.S., 1959. Additive and dominance effects of genes in egg production and ten-week body weight of crossbreed chickens. Poultry Sci., 38: 284-287.

YAO, T.S., 1961. Genetic variations in the progenies of the diallel crosses of imbread lines of chickens. Poultry Sci., 40: $1048-1059$. 
7. TABELAS DE RESULTADOS 


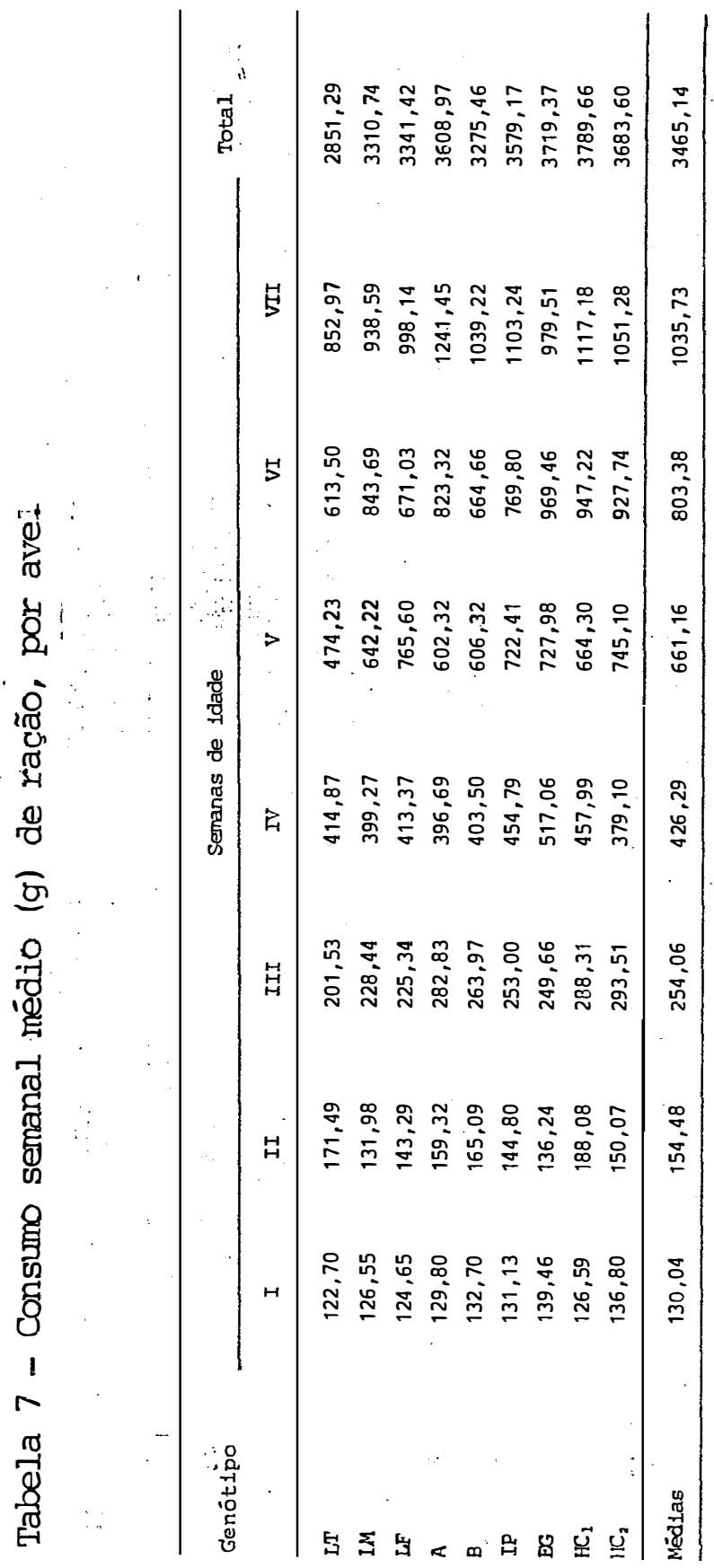




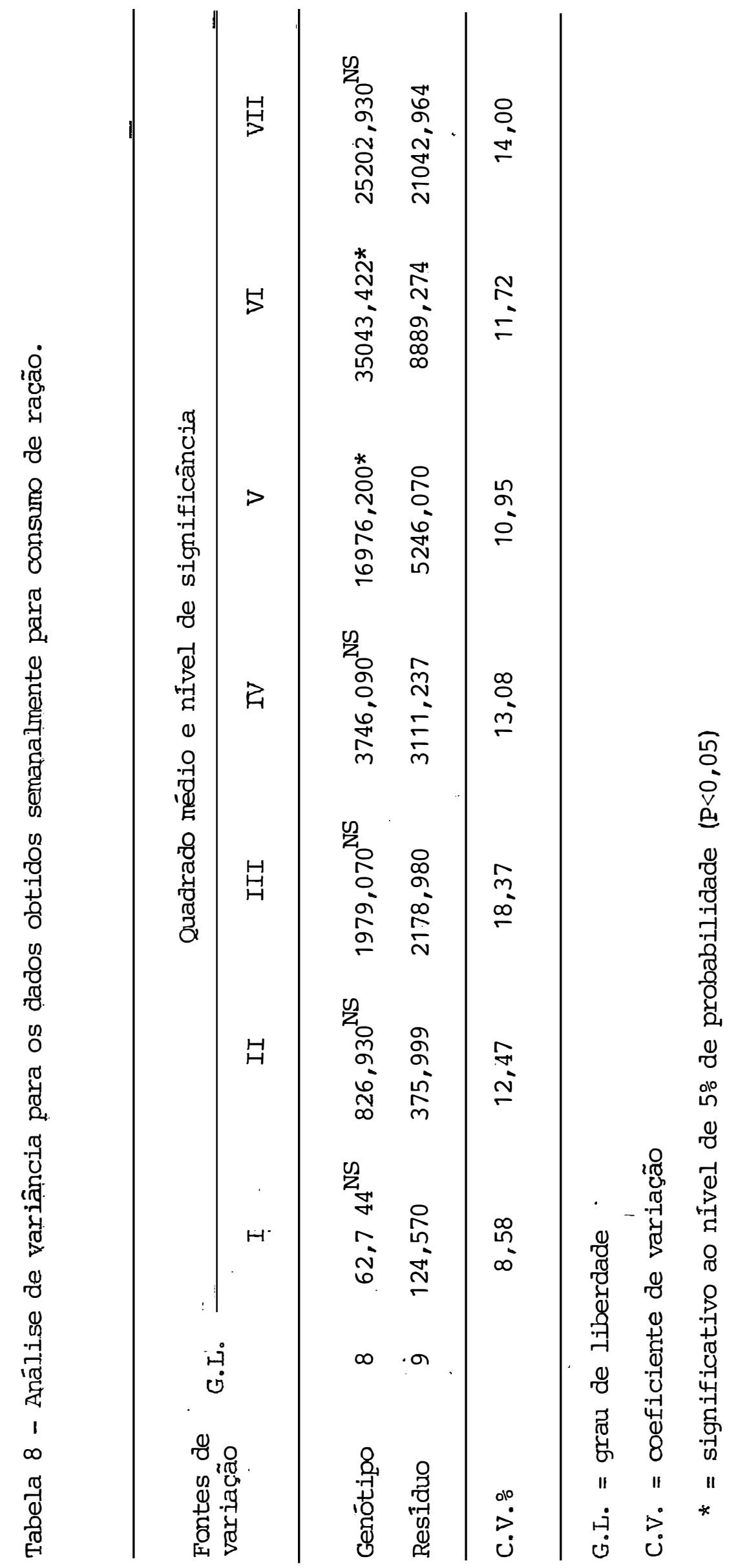


81.

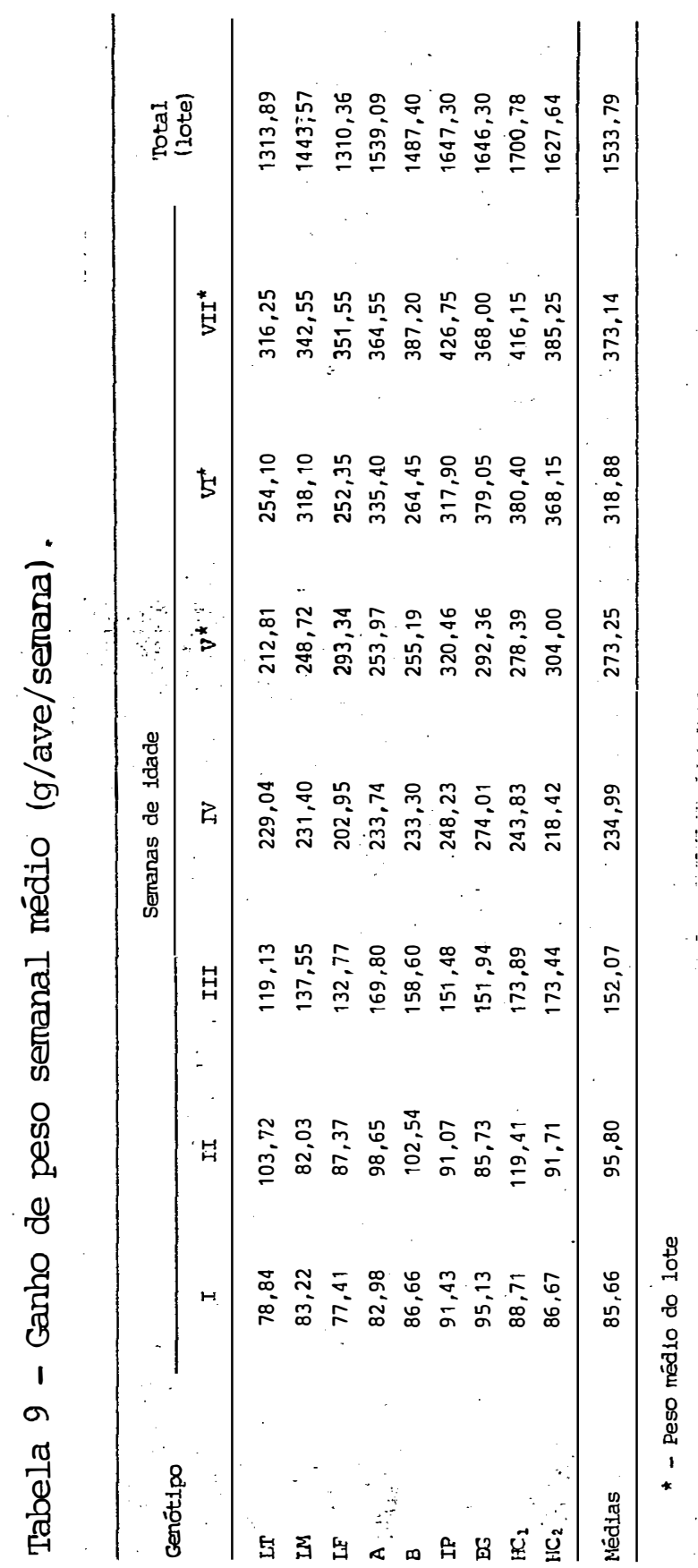




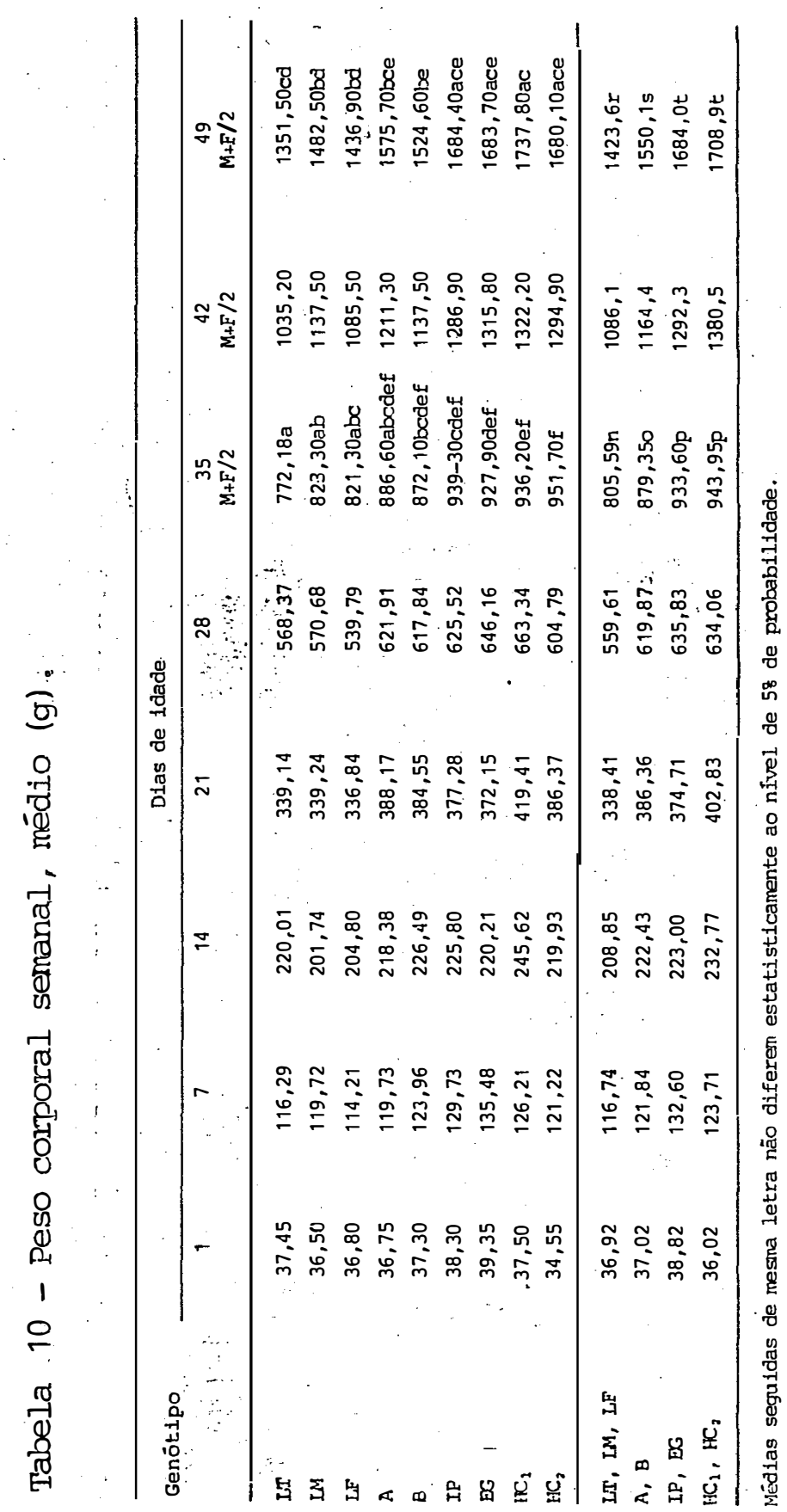


83.

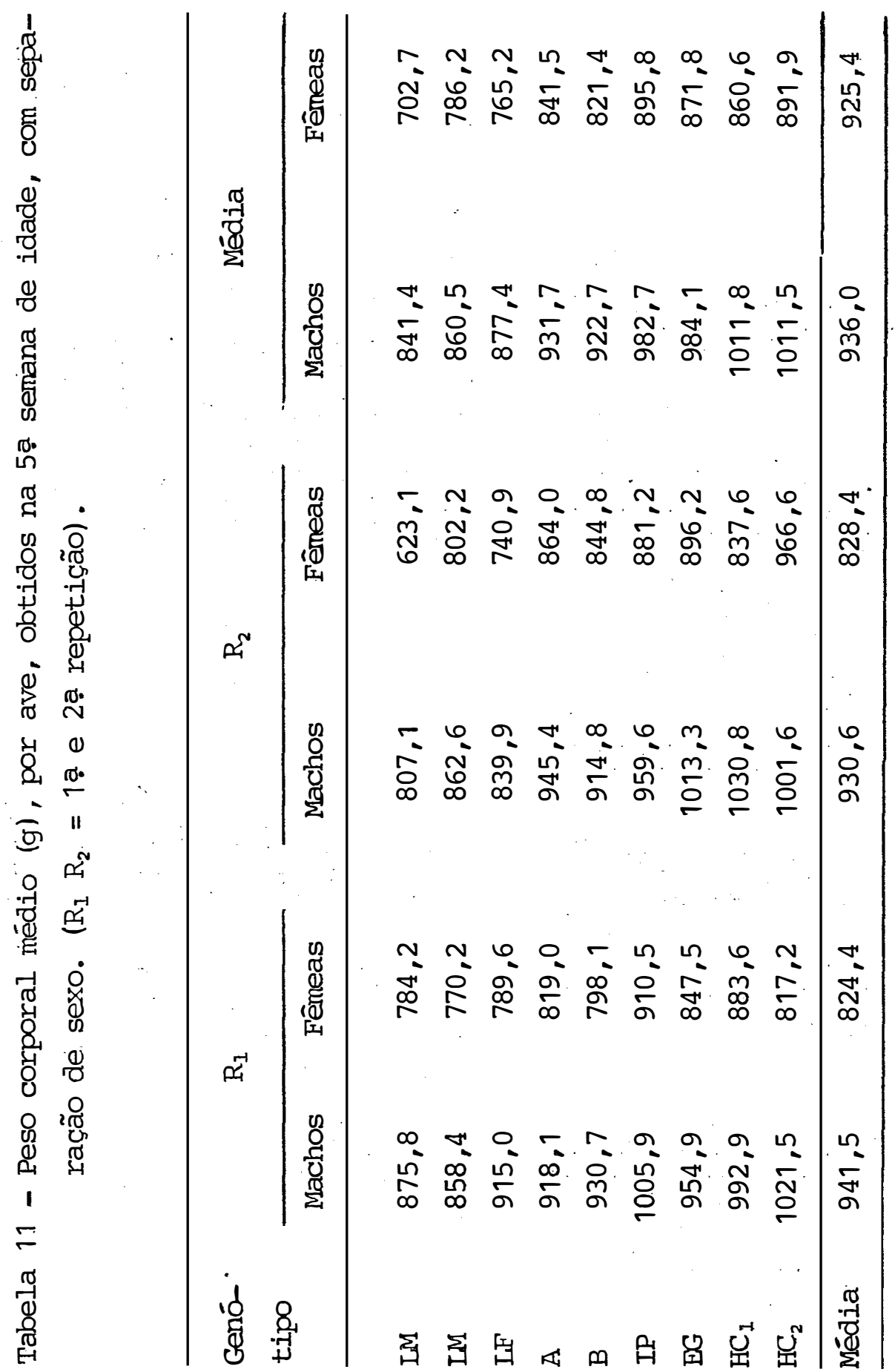




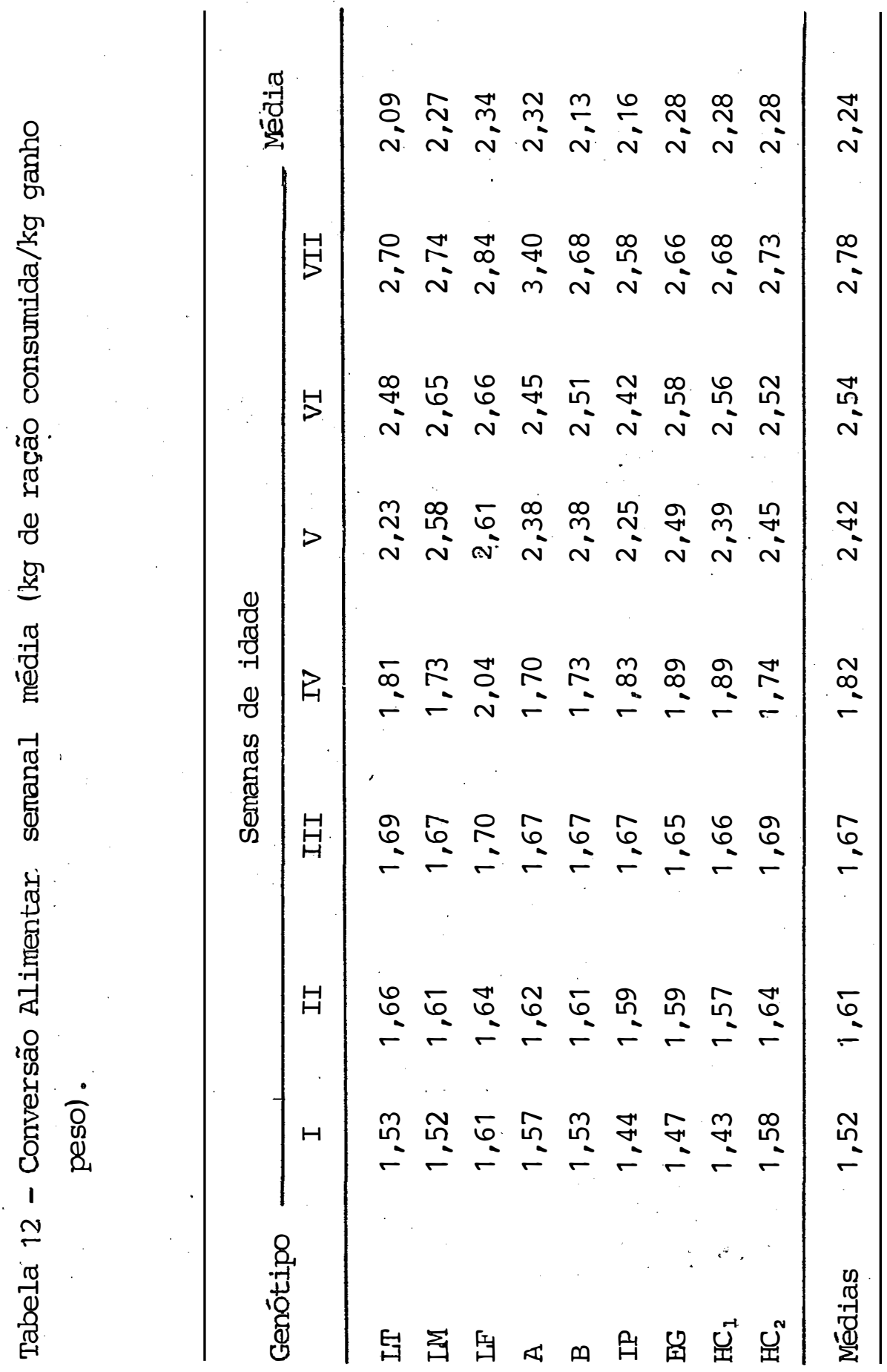




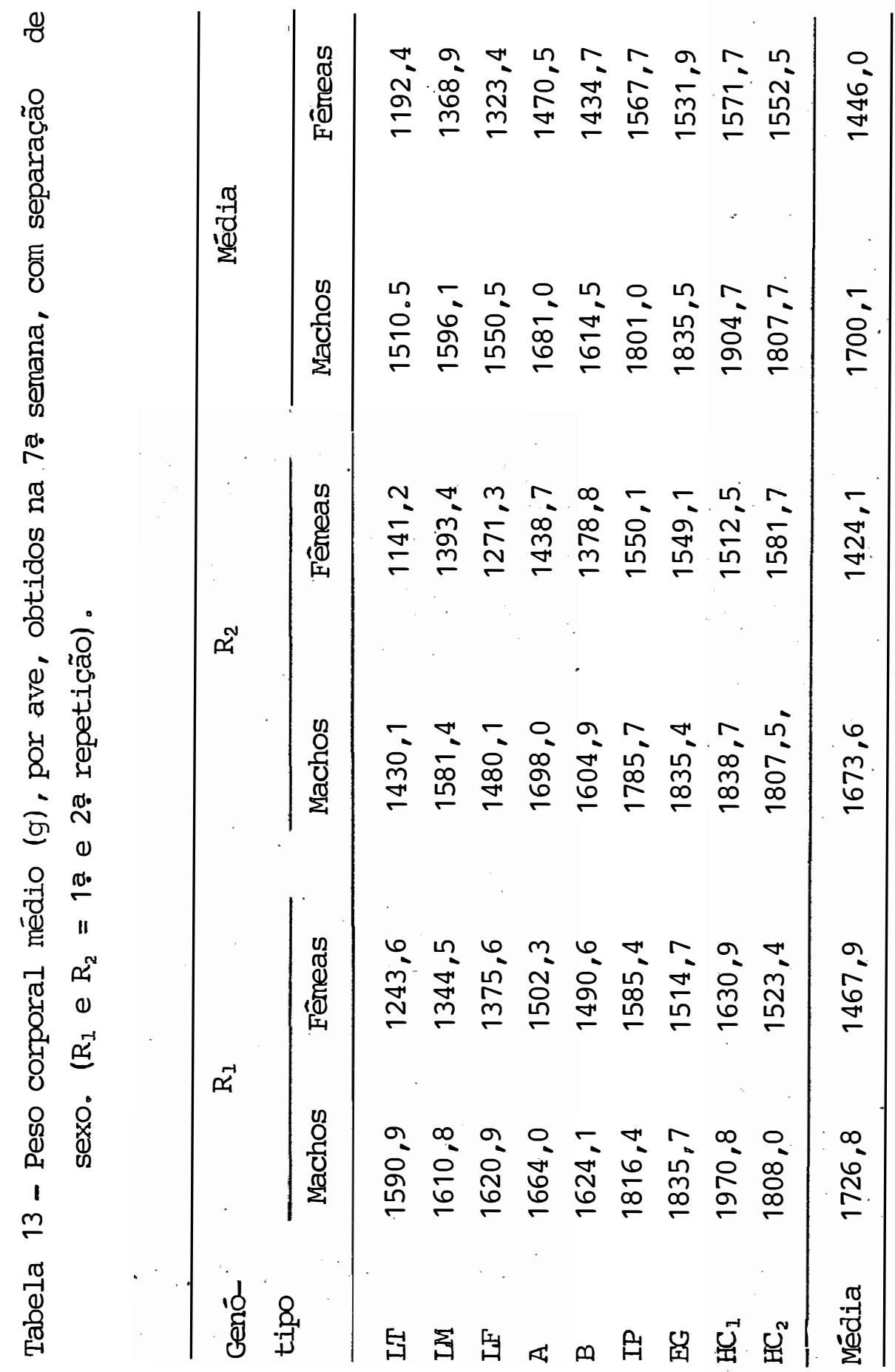


86.

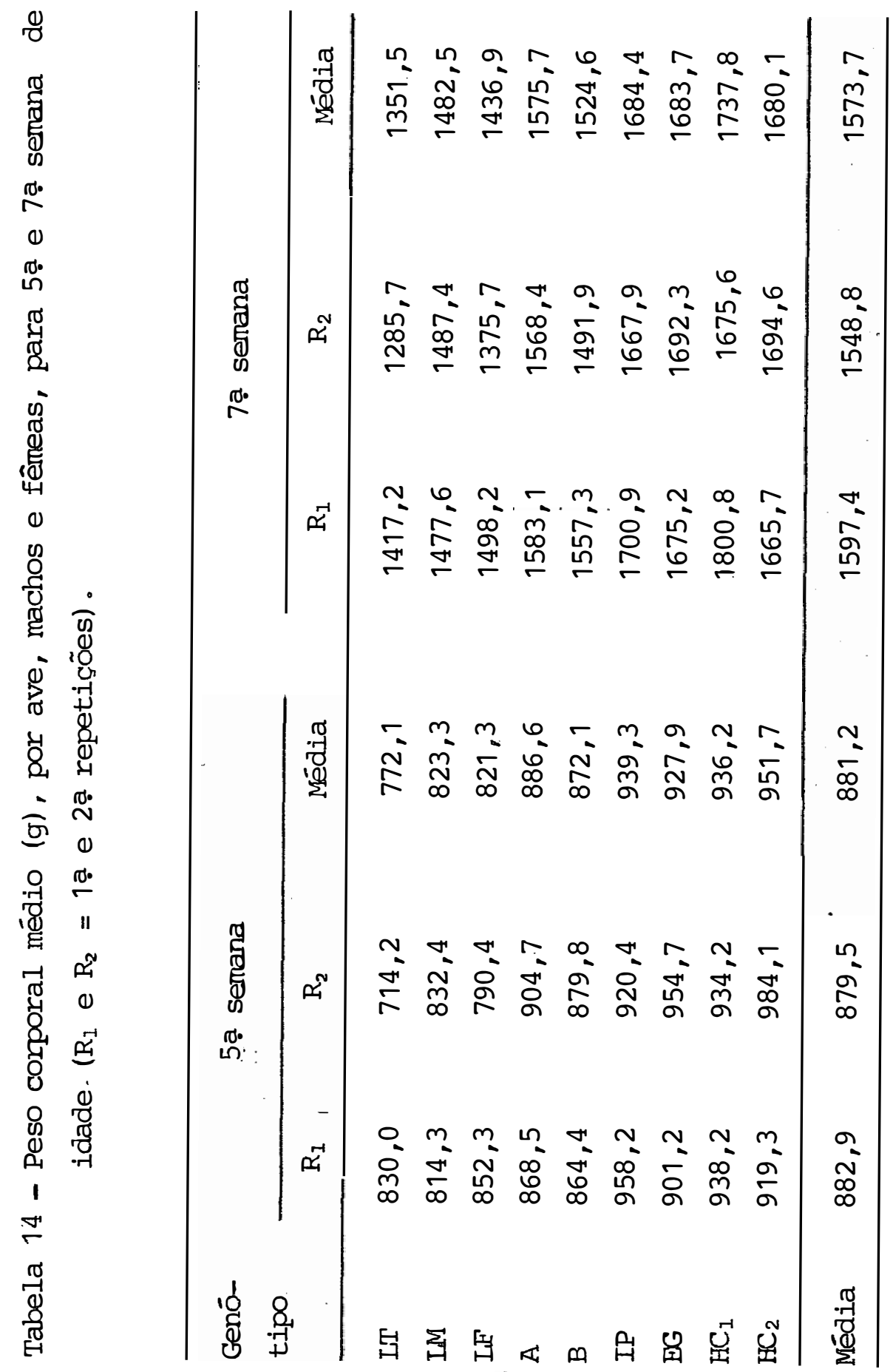


87.

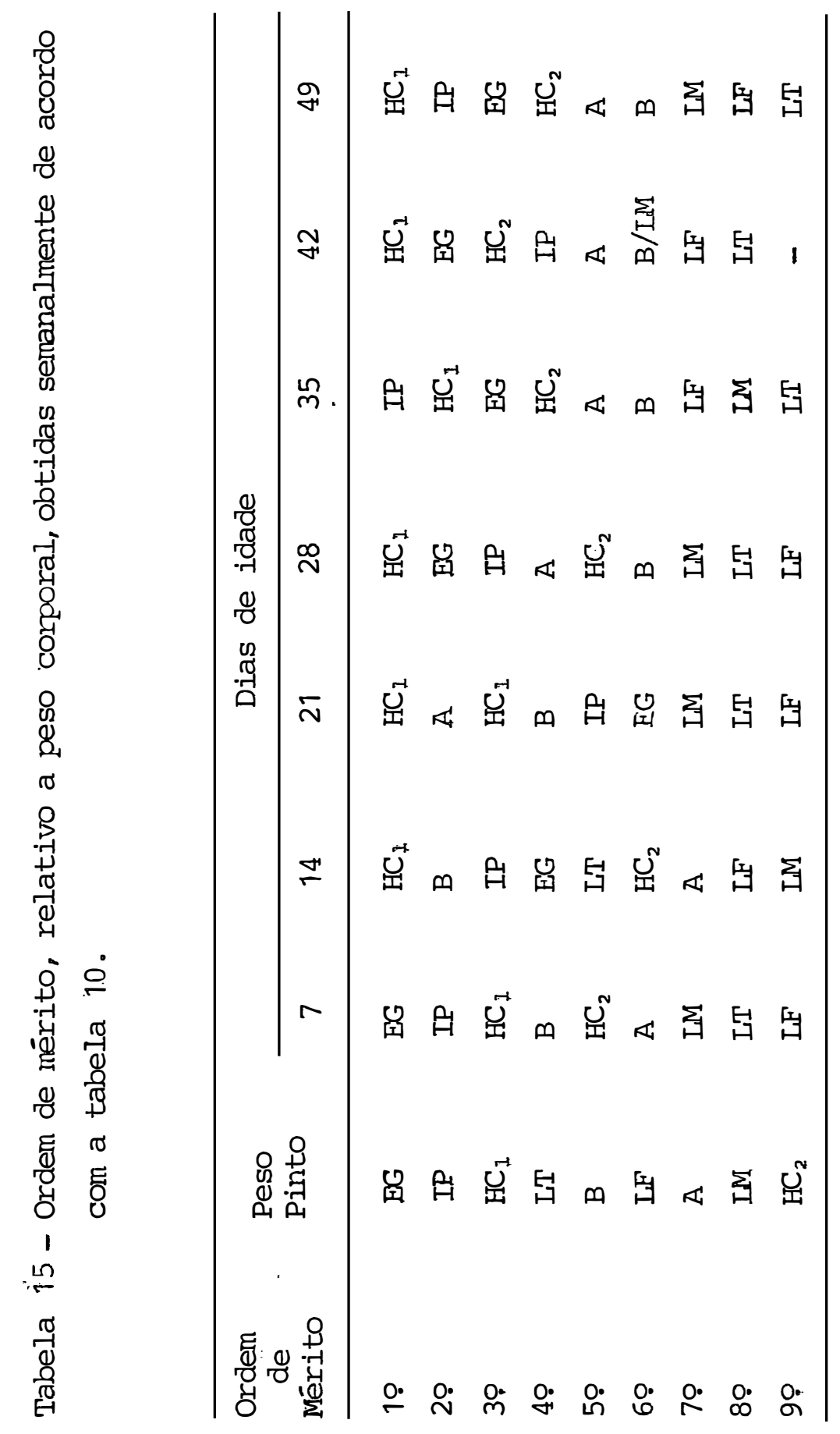


88.

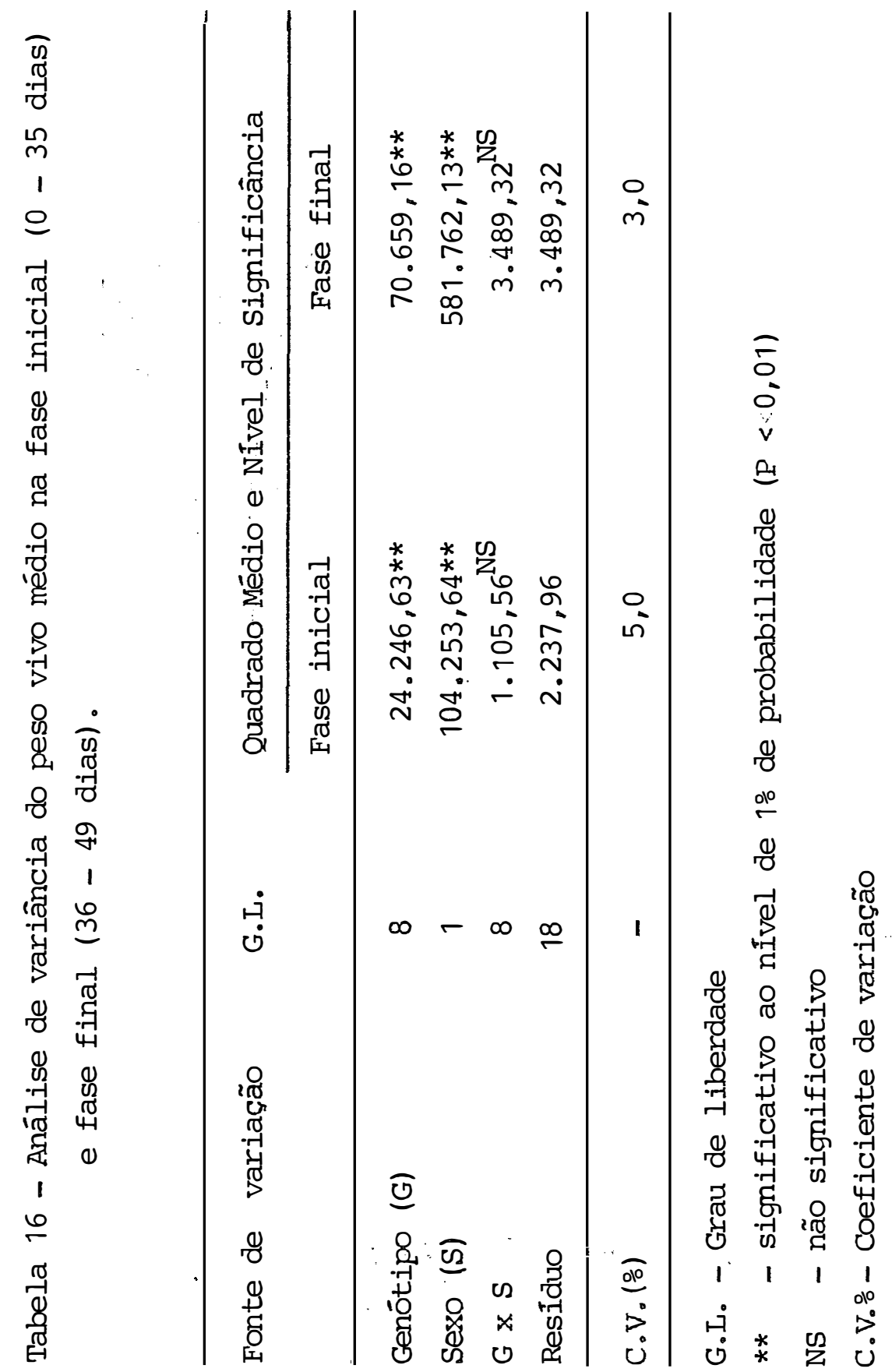


89.

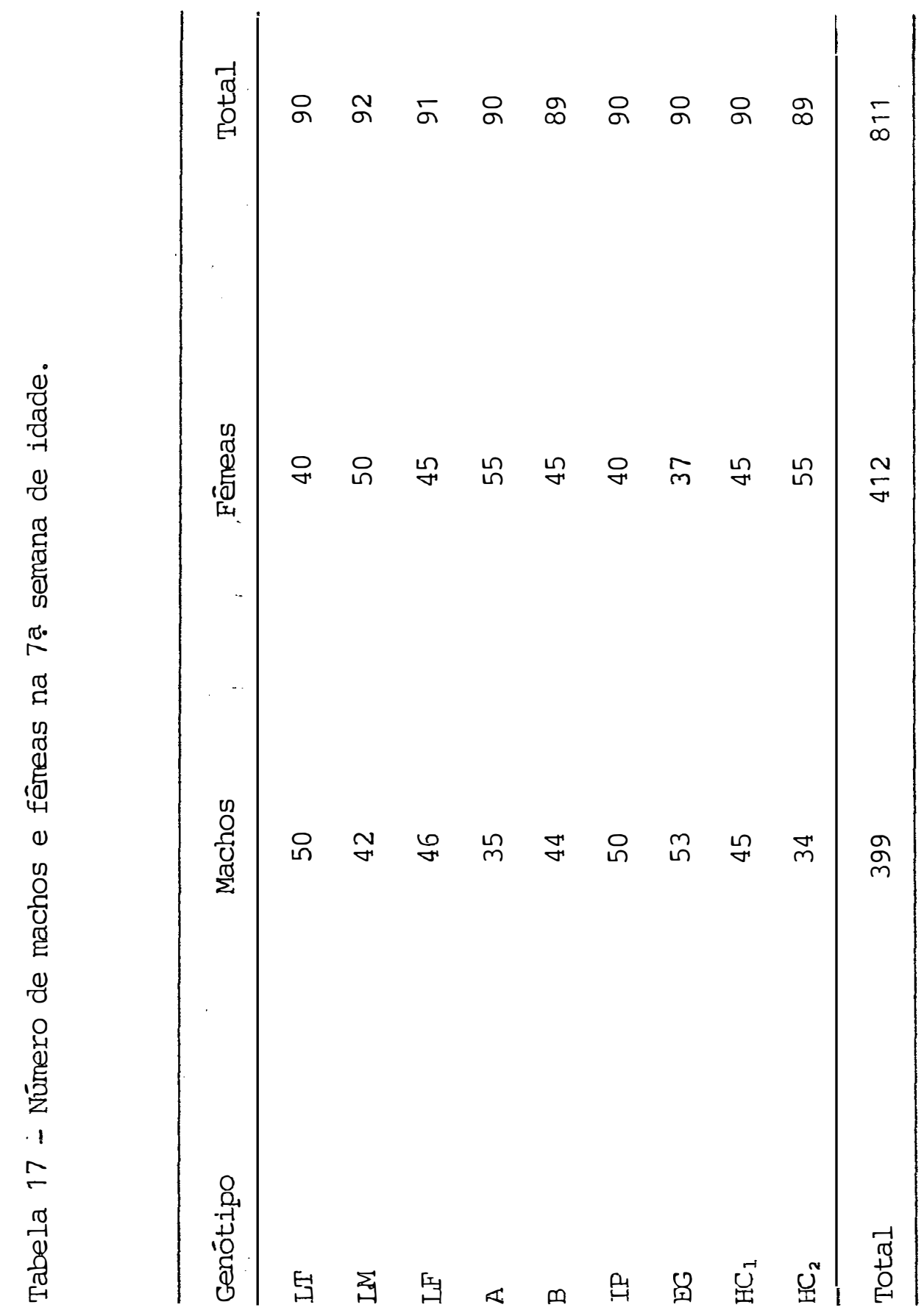


90.

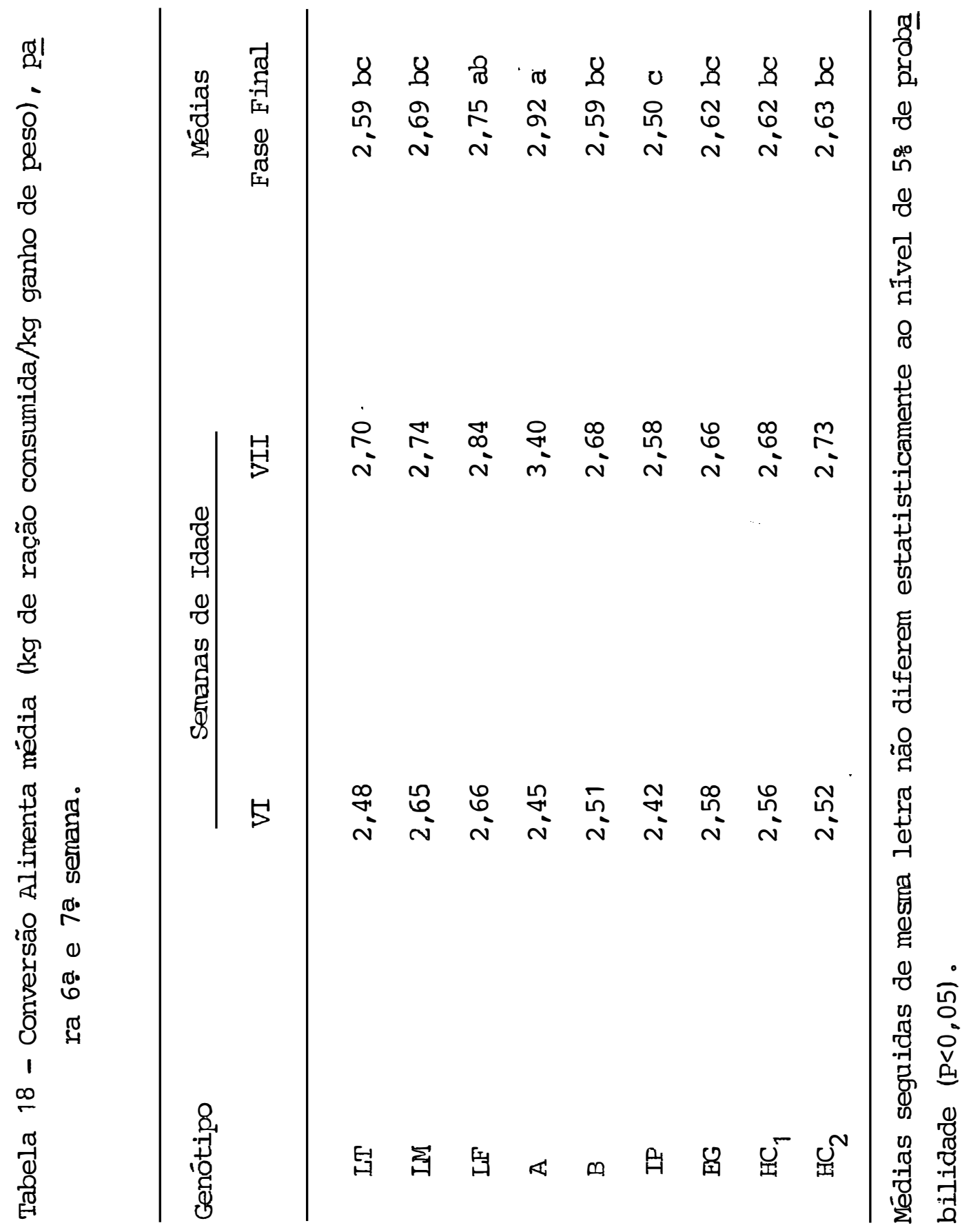


91.

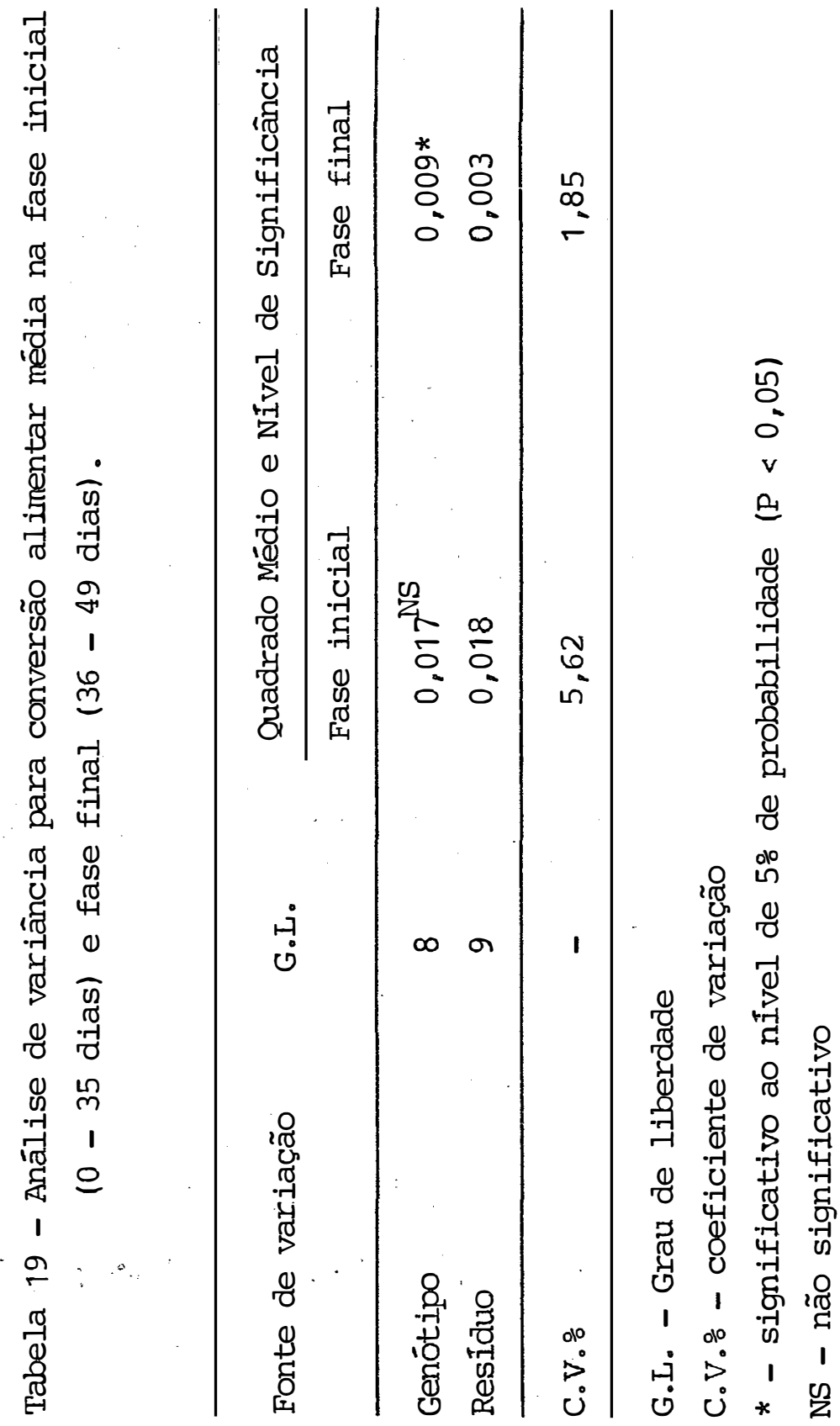


Tabela 20 - Ordem de mérito, relativo a peso corporal e conversão alimentar para 6ă e 7ạ semana de idade.

\begin{tabular}{|c|c|c|c|c|}
\hline \multirow{2}{*}{$\begin{array}{l}\text { Ordem de } \\
\text { mérito }\end{array}$} & \multicolumn{2}{|c|}{ Peso corporal (semanas) } & \multicolumn{2}{|c|}{ Conversão alimentar } \\
\hline & VI & VII & VI & VII \\
\hline 10 & $\mathrm{HC}_{1}$ & $\mathrm{HC}_{1}$ & IP & IP \\
\hline 29 & $E G$ & IP & A & $E G$ \\
\hline 39 & $\mathrm{HC}_{2}$ & ECE & $\mathrm{LT}$ & $\mathrm{HC}_{1}-\mathrm{B}$ \\
\hline 49 & IP & $\mathrm{HC}_{2}$ & B & IT \\
\hline 50 & A & A & $\mathrm{HC}_{2}$ & $\mathrm{HC}_{2}$ \\
\hline 60 & B-IM & B & $\mathrm{HC}_{1}$ & IM \\
\hline 70 & IF & LM & $E G$ & $I F$. \\
\hline 80 & $\mathrm{LT}$ & $L F$ & IM & A \\
\hline 99 & - & LT & LF & - \\
\hline
\end{tabular}




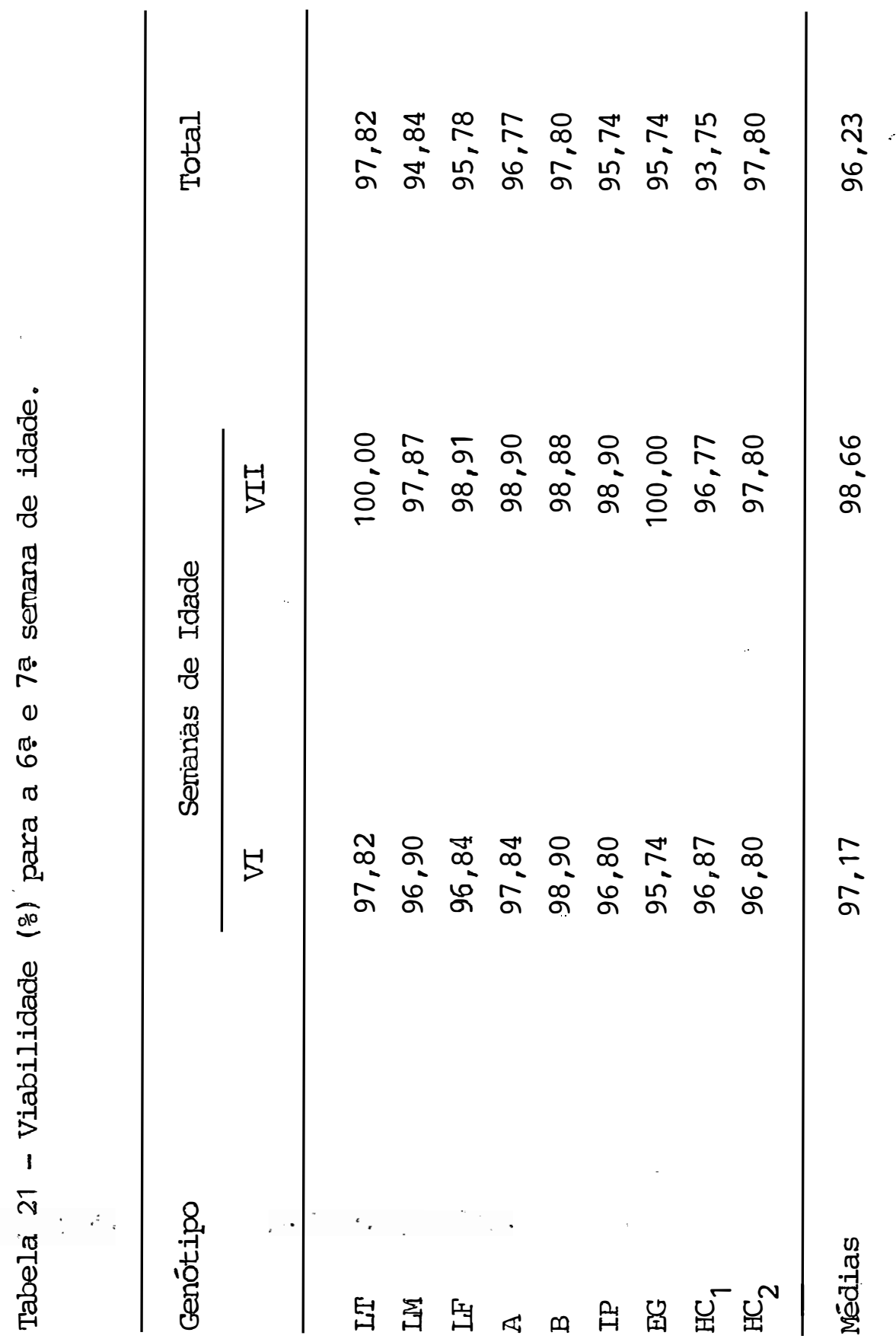


Tabela 22 - Desempenho geral de 0 - 49 dias.

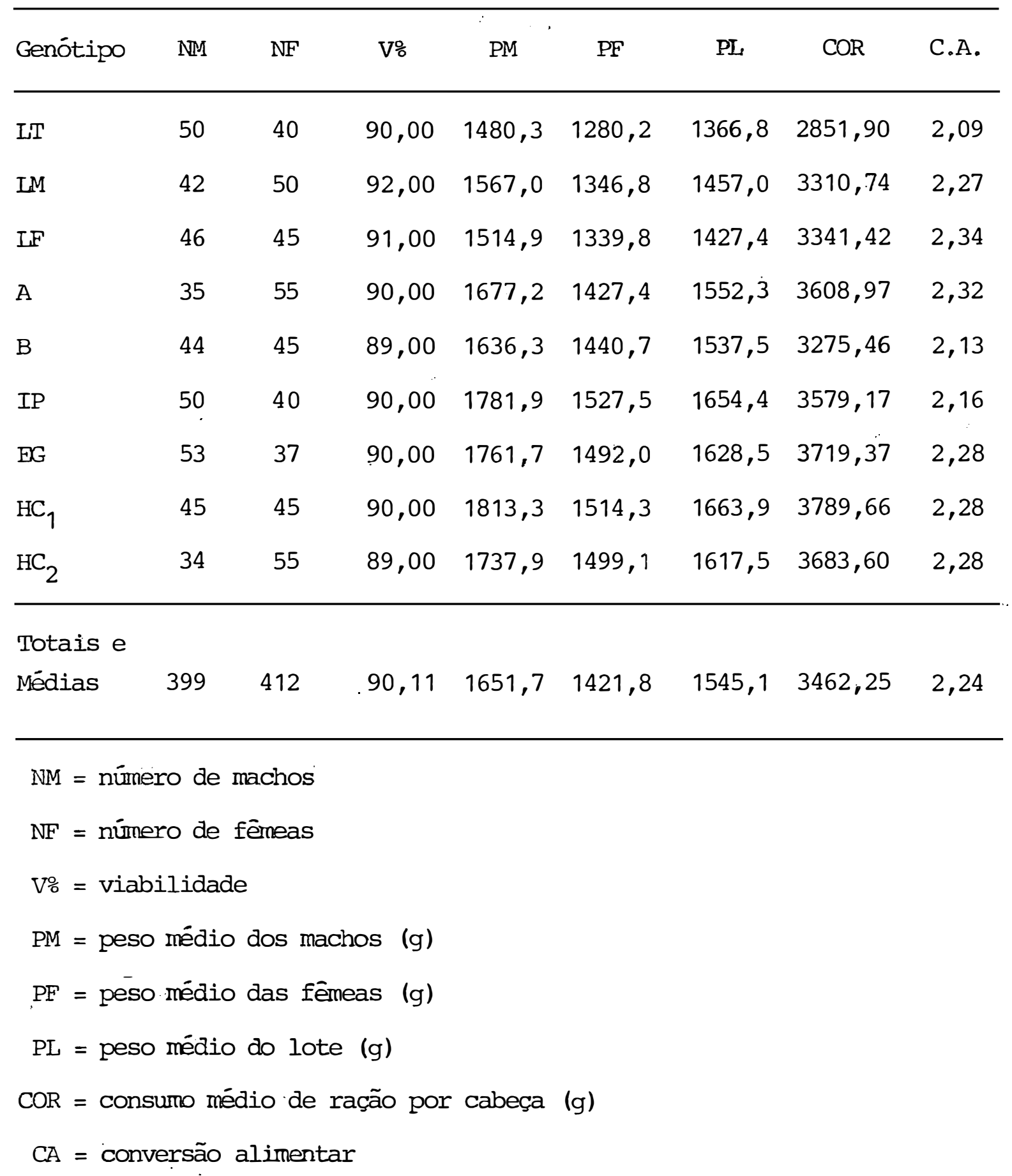


Tabela 23 - Desempenho das nopulações e hỉbridos comerciais de 0 a 49 dias.

\begin{tabular}{lcccccc}
\hline & \multicolumn{5}{c}{ Caracteristicas } \\
\cline { 2 - 6 } Genótipo & NM & NF & PL & CR & C.A. & Vo \\
\hline LT, LM e LF & 138 & 135 & 1417,1 & 3168,0 & 2,23 & 91,0 \\
A e B & 79 & 100 & 1544,9 & 3442,2 & 2,22 & 89,5 \\
IP e EG & 103 & 77 & 1641,5 & 3649,3 & 2,22 & 90,0 \\
HC e HC 2 & 79 & 100 & 1641,2 & 3736,6 & 2,28 & 89,5 \\
\end{tabular}

NM = número de machos.

$\mathrm{NF}$ = número de fêmeas.

$\mathrm{PL}=$ peso médio do lote $(\mathrm{g})$.

COR = consumo médio de ração por cabeça $(g)$.

$C A=$ conversão alimentar

$\mathrm{V} \%$ = viabilidade. 


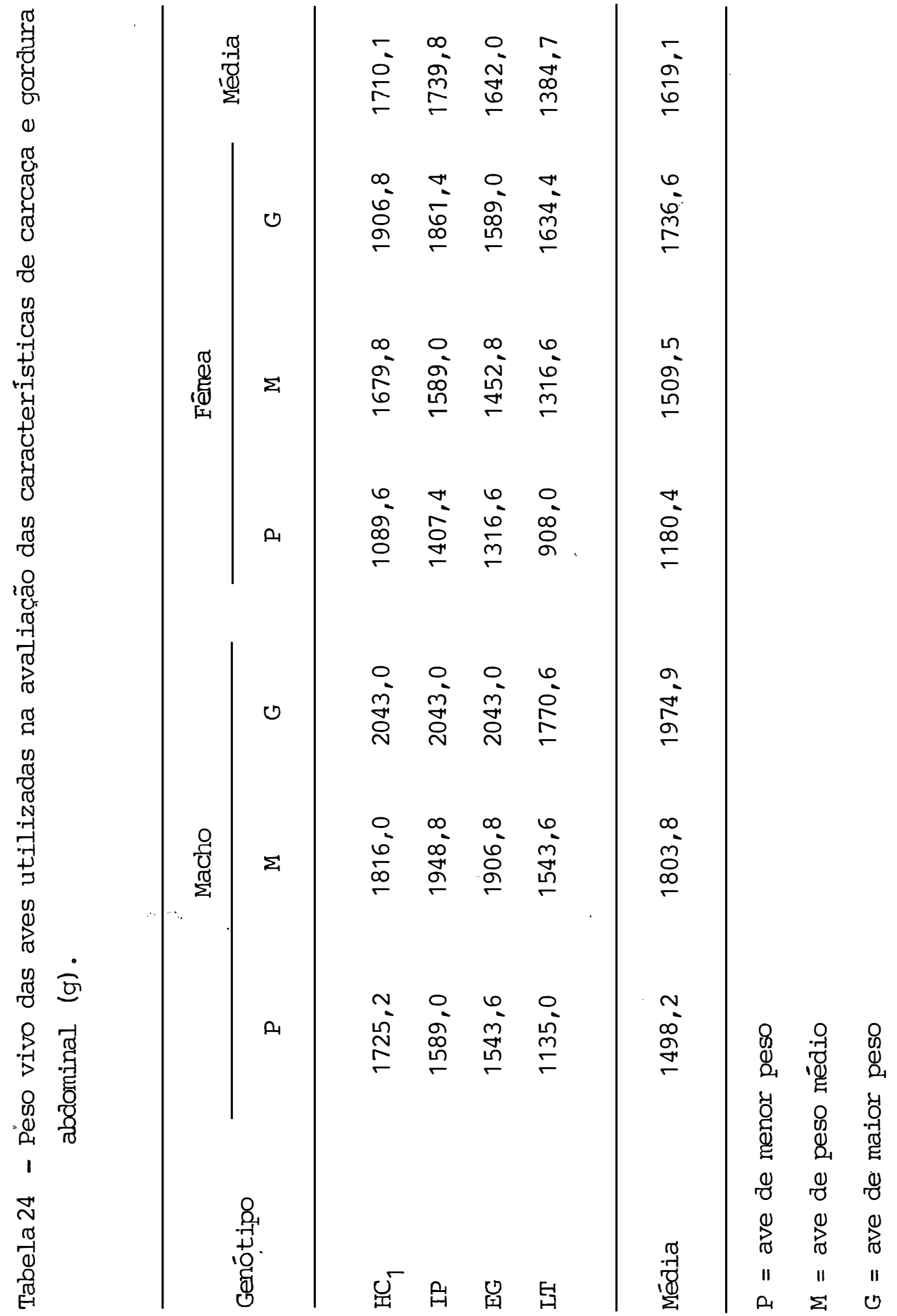


97.

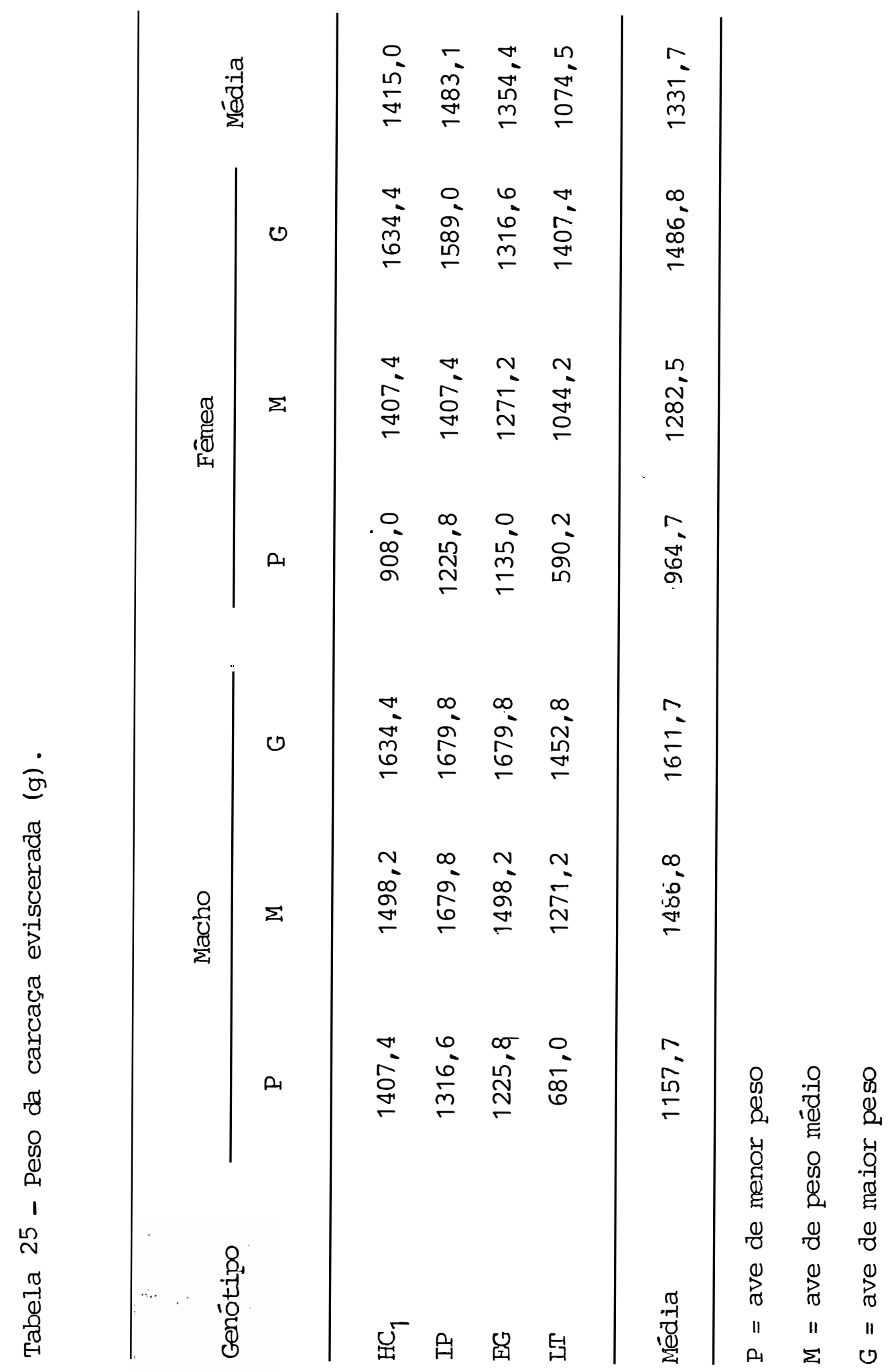




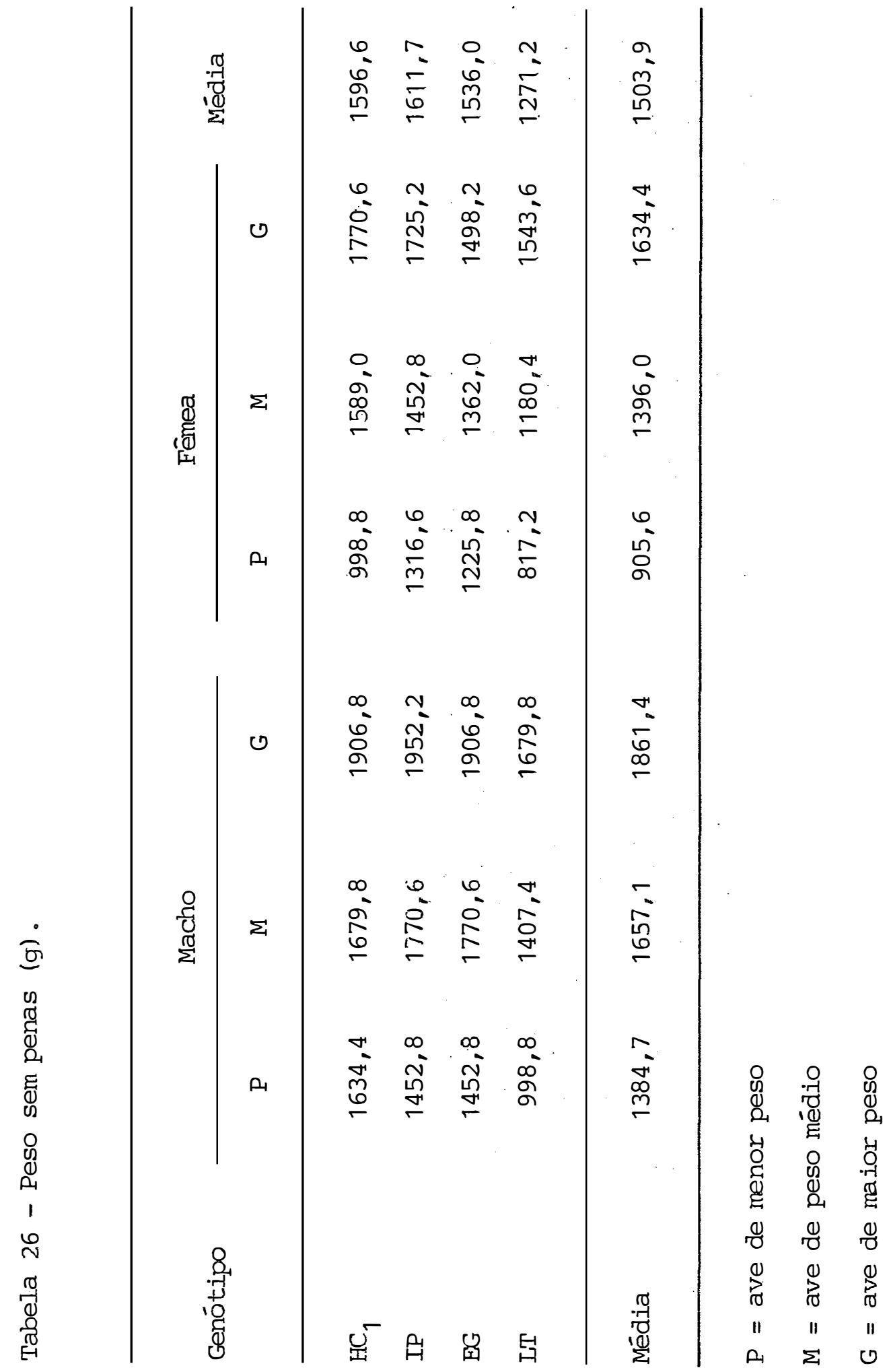




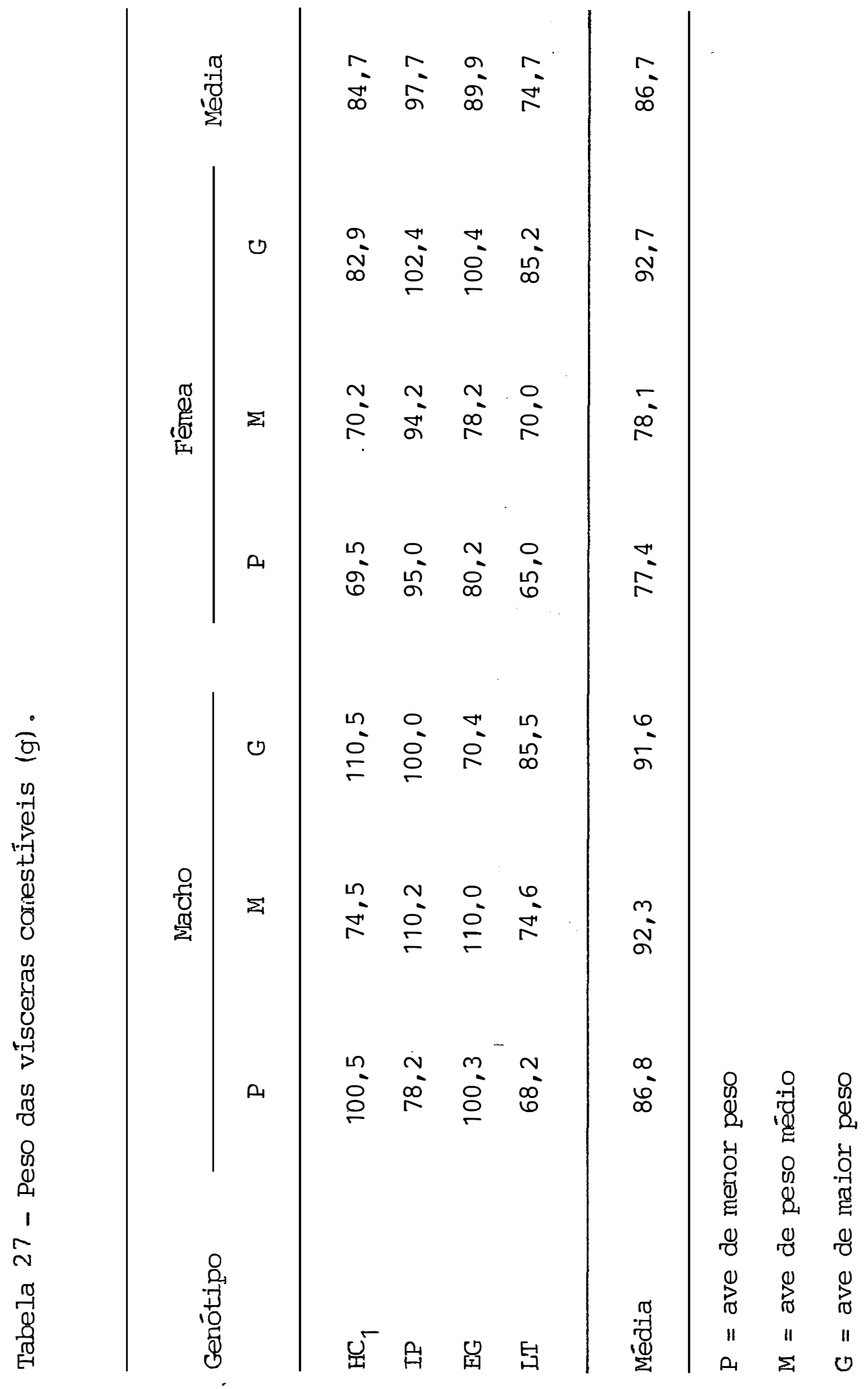


100.

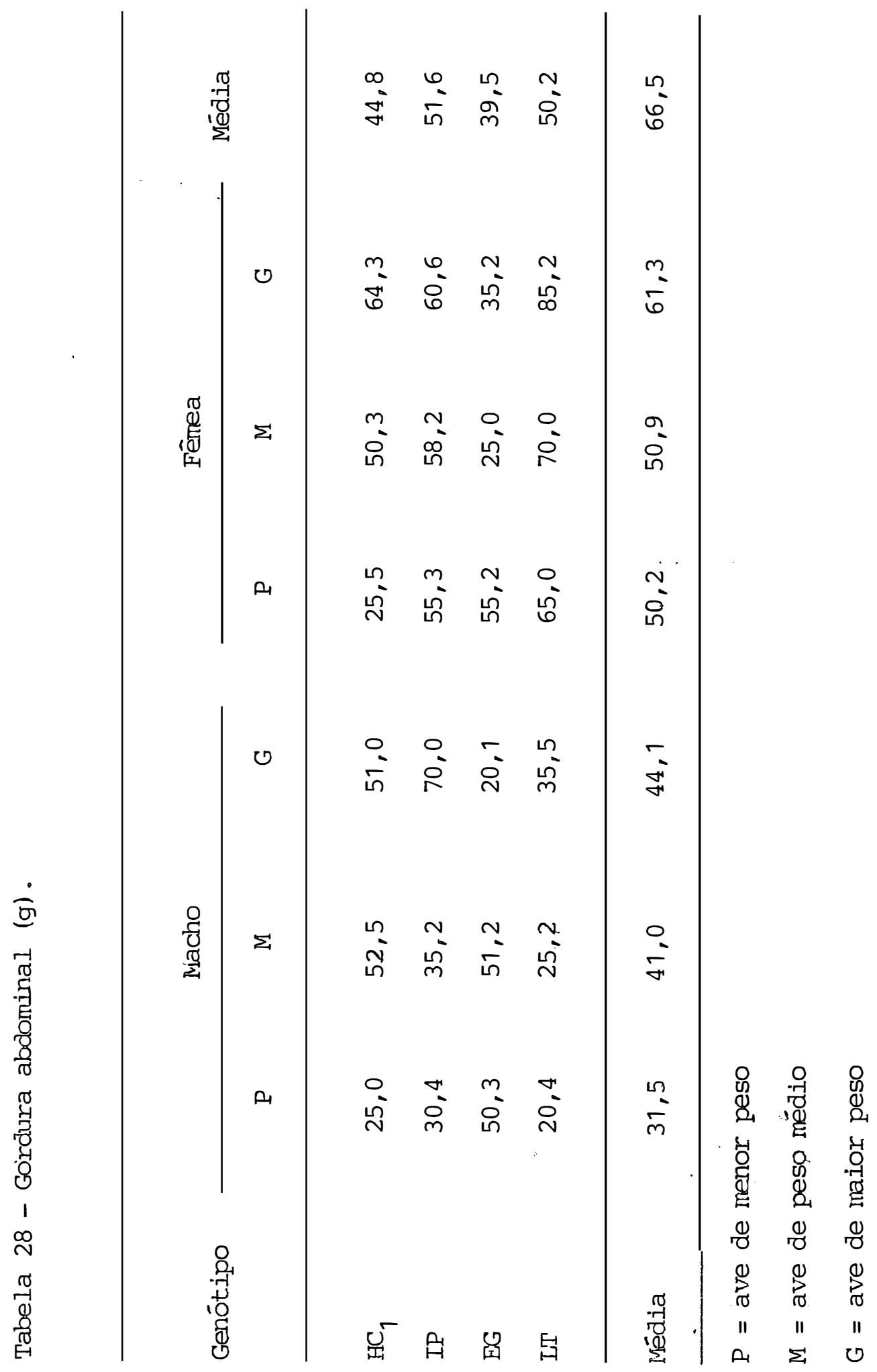


101.

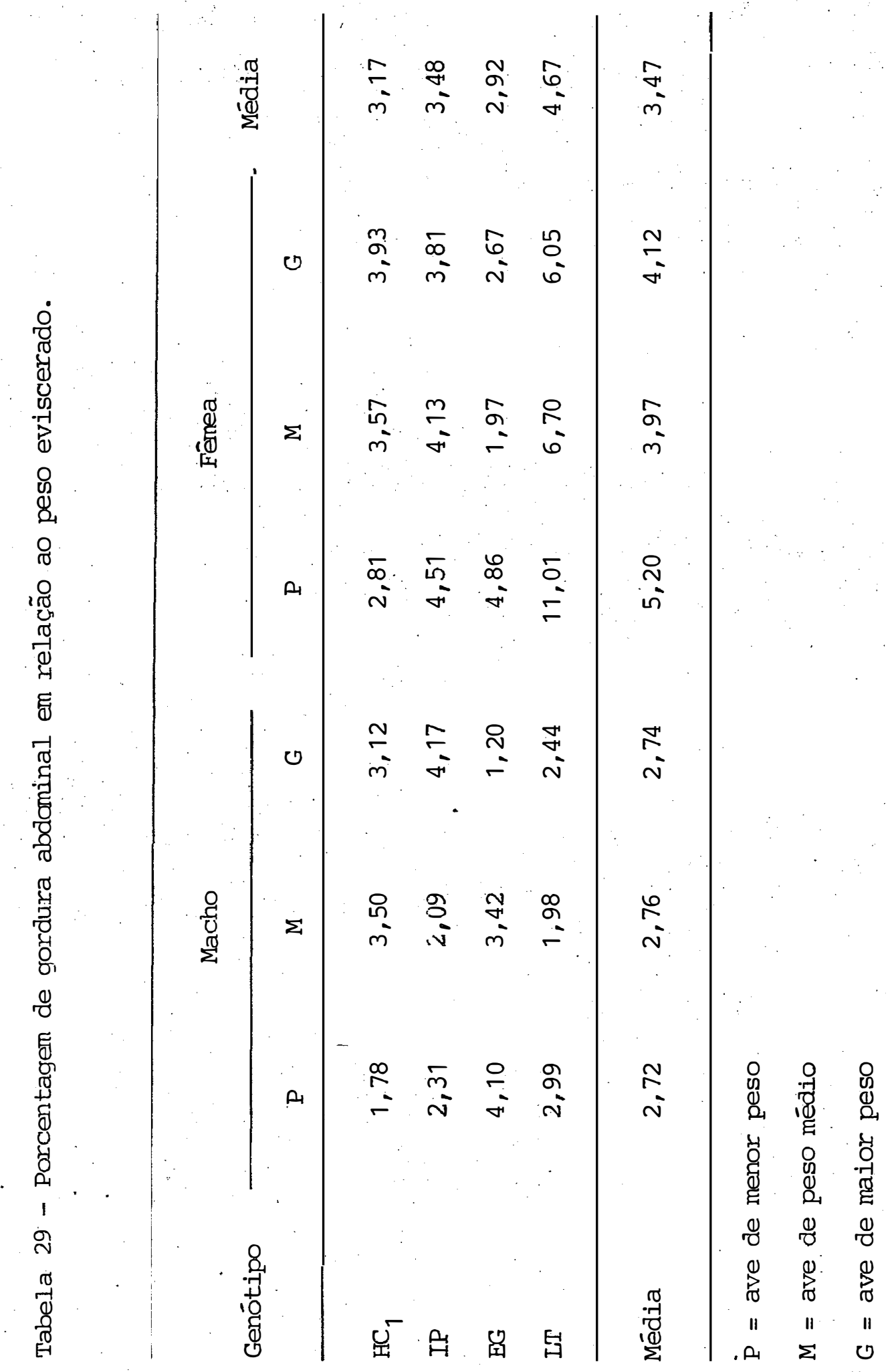




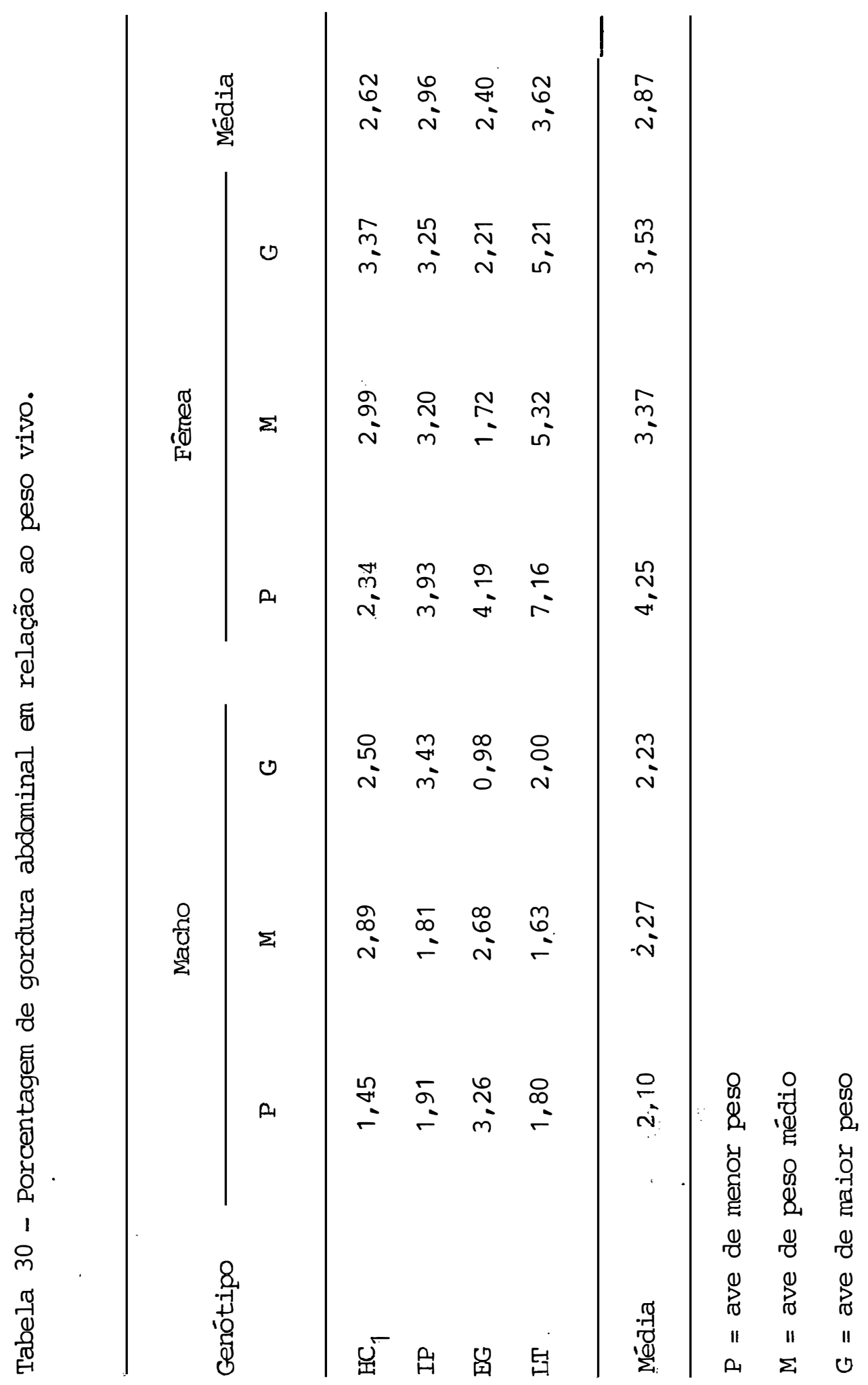




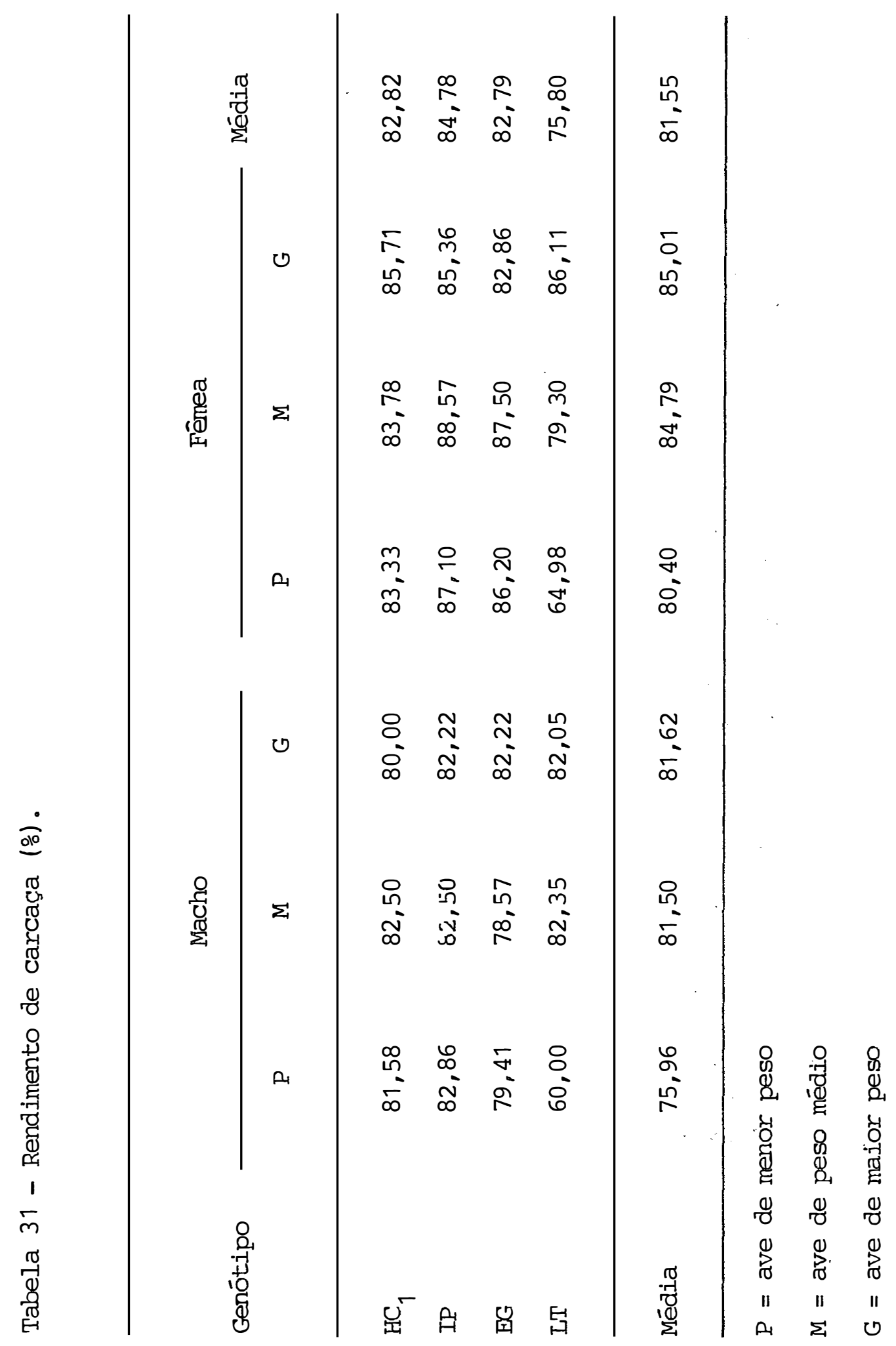


Tabela 32 - Peso vivo (PV), peso sem penas (PSP), peso da carcaça (PC), pe so das visceras comestiveis (PVC) e peso da gordura abdominal $(P G)$, em gramas.

\begin{tabular}{|c|c|c|c|c|c|c|}
\hline Genōtipo & Sexo & PV & PSP & PC & PVC & PG \\
\hline \multirow[t]{3}{*}{$\mathrm{HC}_{1}$} & macho & 1861,4 & 1740,3 & 1513,3 & 95,2 & 42,8 \\
\hline & fêmea & 1558,7 & 1452,8 & 1316,6 & 74,2 & 46,7 \\
\hline & média & 1710,0 & 1596,5 & 1414,9 & 84,7 & 44,7 \\
\hline \multirow[t]{3}{*}{ IP } & macho & 1860,3 & 1725,2 & 1558,7 & 96,1 & 45,2 \\
\hline & fêmea & 1619,3 & 1498,2 & 1407,4 & 97,2 & 58,0 \\
\hline & média & 1739,8 & 1611,7 & 1483,0 & 96,6 & 51,6 \\
\hline \multirow[t]{3}{*}{$L T$} & macho & 1483,1 & 1362,0 & 1135,0 & 76,1 & 27,0 \\
\hline & fêmea & 1286,3 & 1180,4 & 1013,9 & 73,4 & 45,1 \\
\hline & média & 1384,7 & 1271,2 & 1074,4 & 74,7 & 36,0 \\
\hline
\end{tabular}




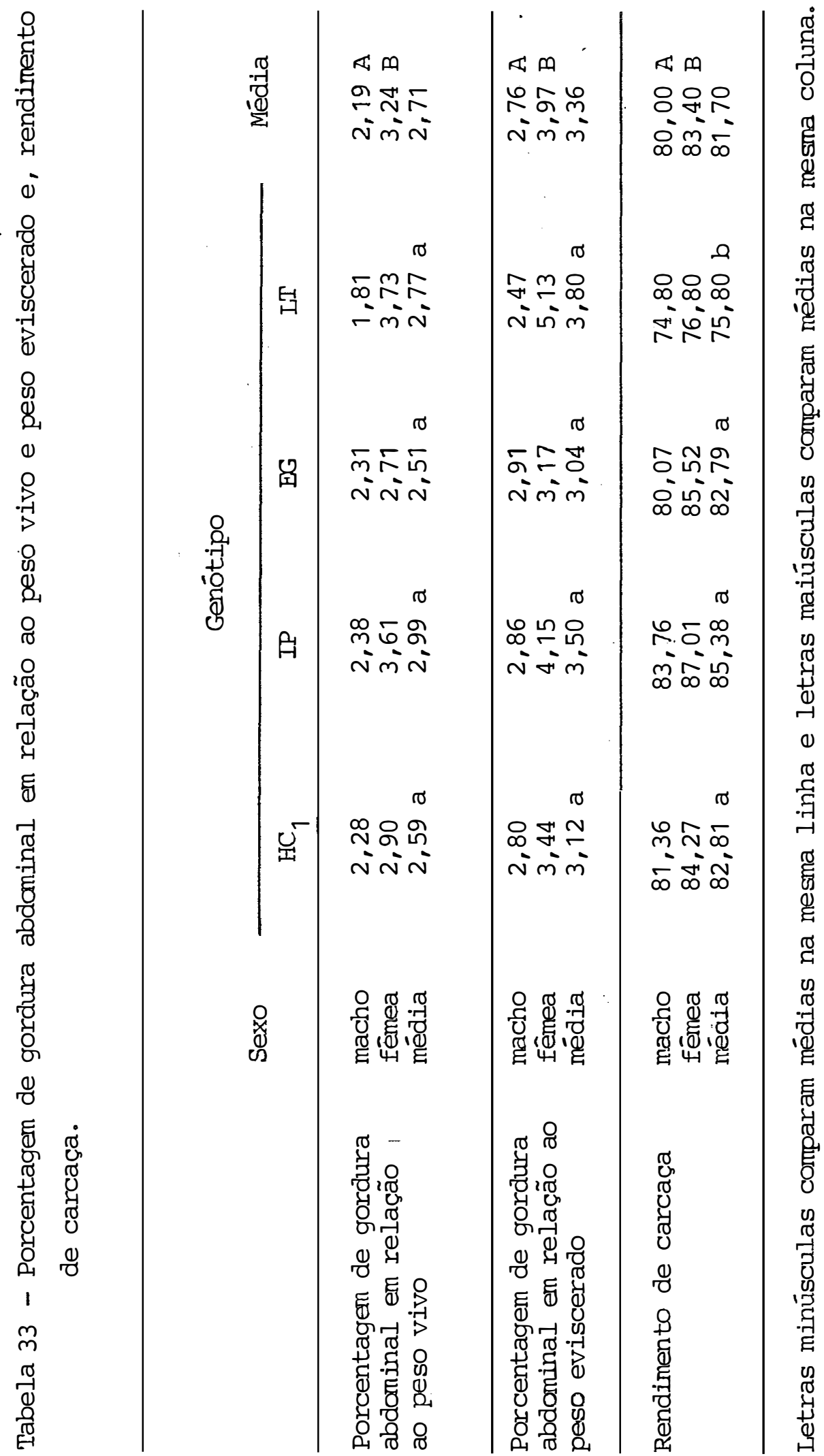


106.

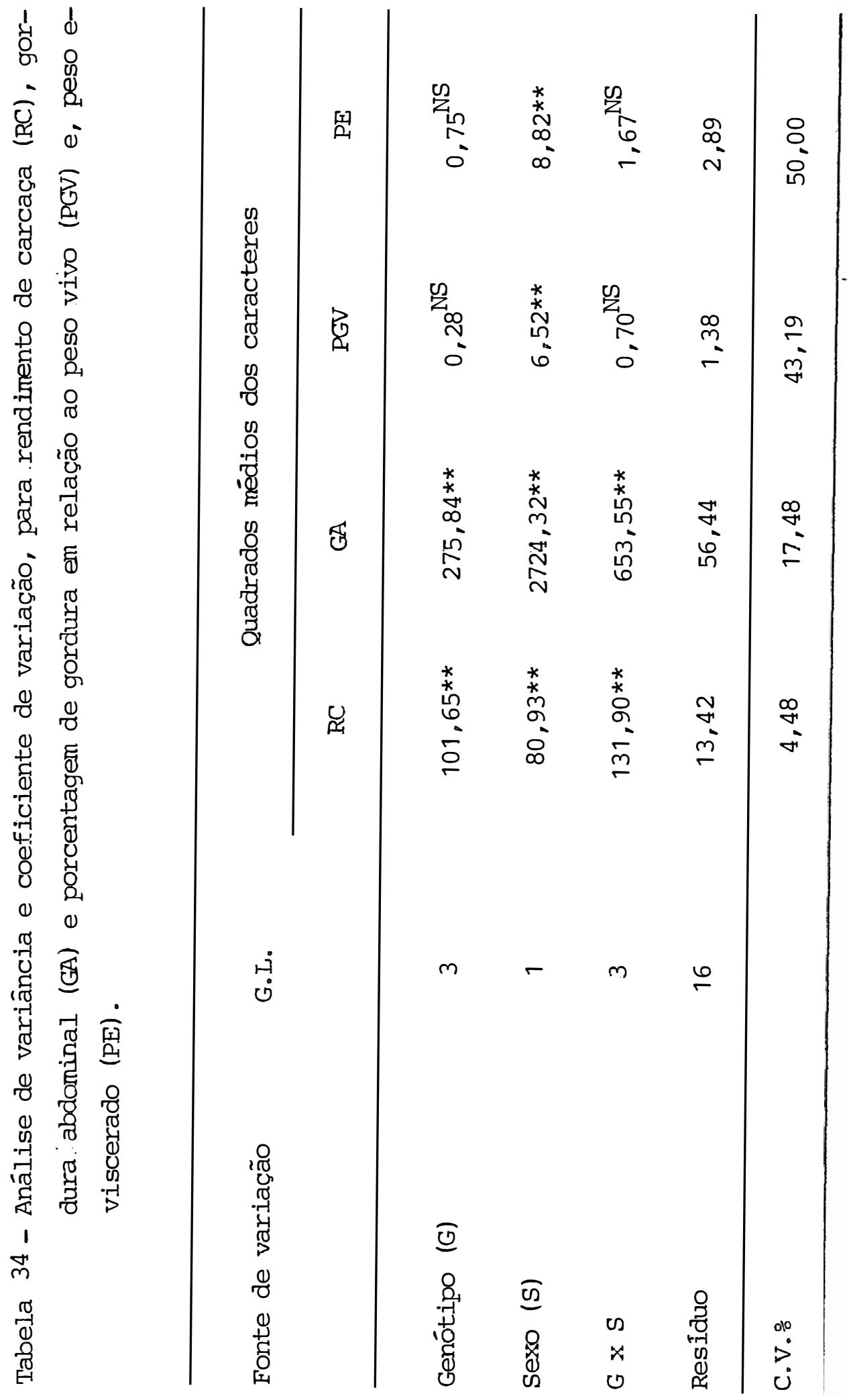


Tabela 35 - Coeficiente de correlação (r) e equação de regressão (ER) para características de carcaça.

Partes correlacionadas

ER

\begin{tabular}{llll}
\hline P. vivo & x P. sem penas & 0,997 & $y=0,968 x-63,556$ \\
P. vivo x P. gordura & $-0,010$ & $y=-0,0007 x-47,64$ \\
P. vivo x P. carcaça & 0,970 & $-y=0,918 x-156,000$ \\
P. vivo x P. vísceras & 0,585 & $y=0,028 x+40,740$ \\
P.carcaça x P. vísceras & 0,306 & $y=0,012 x+70,706$ \\
P.carcaça x P. gordura & 0,110 & $y=0,007 x+37,433$ \\
P.visceras x P. gordura & 0,418 & $y=0,552 x-2,84$ \\
& & \\
\hline
\end{tabular}

